\title{
CLASS CERTIFICATION AND THE SUBSTANTIVE MERITS
}

\author{
ROBERT G. BONE $\dagger$ \\ DAVID S. EVANS $\dagger \dagger$
}

\begin{abstract}
The United States Supreme Court, in its 1974 decision, Eisen v. Carlisle \& Jacquelin, held that judges should not conduct a preliminary inquiry into the merits of a suit as part of the decision whether to certify a class. The federal courts have struggled ever since to honor Eisen's bar while still conducting a credible certification analysis-a task complicated by the fact that merits-related factors are often relevant to Rule 23 requirements. The result is a muddled body of case law in which courts tend to certify generously and avoid inquiring into the merits of substantive issues even when those issues are crucial to the certification analysis. This approach creates high social costs by inviting frivolous and weak class action suits. This Article argues that the Eisen rule should be abolished. Trial judges should assess competing evidence, not just allegations, and should evaluate case strength whenever the specific requirements of Rule 23 call for an inquiry into merits-related factors. For example, a party relying on a substantive issue to show commonality or predominance should have to demonstrate a likelihood of success on the issue. The Article also goes further and recommends that judges always conduct a preliminary inquiry into the merits before certifying a class, regardless of whether
\end{abstract}

Copyright $(2002$ by Robert G. Bone and David S. Evans.

$\dagger$ Professor of Law, Boston University School of Law. J.D., Harvard University, 1978. I wish to thank my research assistant, Aravind Swaminathan, for his valuable help.

t† Senior Vice President, National Economic Research Associates. Ph.D. Economics, University of Chicago, 1983.

The authors wish to thank Ronald Cass, Howard Chang, Keith Hylton, and Elliott Weiss for helpful comments. The authors also gratefully acknowledge the financial and administrative support of National Economic Research Associates and Boston University. The views expressed in this Article are those of the authors and do not necessarily reflect the views of National Economic Research Associates or any of its clients. 
merits-related factors are directly relevant to a specific requirement of Rule 23.

The Article first reviews the history of the Eisen rule and surveys the current state of the law, before turning to a policy analysis of the rule's effects. The policy discussion criticizes the traditional arguments and then offers a systematic evaluation of error and process costs. Error costs must be evaluated in light of the extremely high probability of postcertification settlement. Eisen's liberal approach creates a substantial risk of erroneous certification grants that cannot be corrected later when a case settles. This risk coupled with the high likelihood of settlement invites frivolous and weak class action suits. The result is a serious error-cost problem with regard to certification. At the same time, requiring a merits review at the certification stage increases the risk of erroneous certification denials. But for several reasons this risk is not likely to increase dramatically, and the associated costs are not likely to be large. The net result therefore supports a merits inquiry, and this conclusion remains valid even after process costs are added to the policy mix.

\section{TABLE OF CONTENTS}

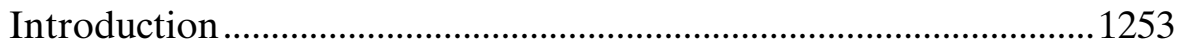

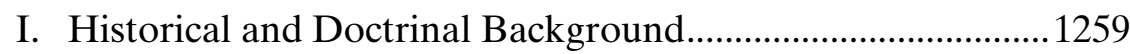

A. Birth of the Certification Procedure.................................1259

B. Early Confrontation with the Merits Issue .......................1263

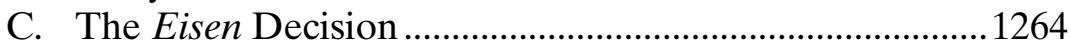

II. Evaluating the Merits After Eisen ...........................................1265

A. The Falcon Decision.........................................................1267

B. Post-Falcon Case Law ........................................................1268

III. A Critical Analysis of the Eisen Rule ....................................... 1276

A. The Alternative: Reviewing the Merits at Certification

B. The Eisen Court's Rationale: Rule 23's Language and Risk of Prejudice....

C. The Substance/Procedure Dichotomy and the Federal Rules Scheme

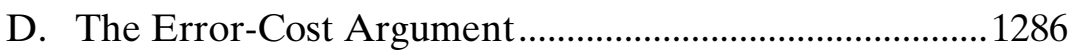

1. The Overall Structure of the Argument: Three Propositions.

2. The Flaws in Proposition 2.

3. The Flaws in Proposition 3. 


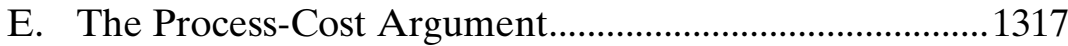

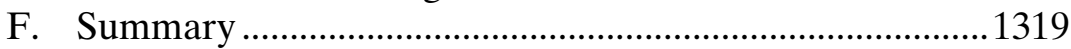

IV. An Example: Caridad v. Metro-North Commuter

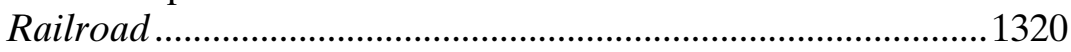

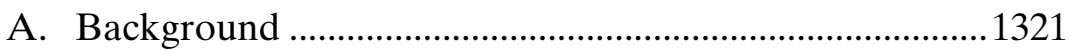

B. District Court Decision .................................................... 1324

C. Court of Appeals Decision ................................................ 1325

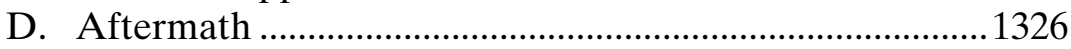

E. Conclusions and Lessons .................................................1326

V. The Ambitious Proposal: A Merits Review for All Cases .... 1328

Conclusion 1330

\section{INTRODUCTION}

Ever since the United States Supreme Court decided Eisen v. Carlisle \& Jacquelin in 1974, ${ }^{1}$ it has been widely accepted doctrine that a judge should not "conduct a preliminary inquiry into the merits of a suit in order to determine whether it may be maintained as a class action." 2 Courts have applied this rule generally to bar merits-related inquiries at the certification stage. ${ }^{3}$ Yet few of these courts offer any convincing rationale for the rule's broad application.

It is time to reexamine the Eisen rule. ${ }^{4}$ The rule was only thinly justified at the time Eisen endorsed it, and developments since Eisen

1. 417 U.S. 156 (1974)

2. Id. at 177 .

3. See, e.g., Caridad v. Metro-North Commuter R.R., 191 F.3d 283, 291 (2d Cir. 1999) (admonishing that "a motion for class certification is not an occasion for examination of the merits of the case"); Koch v. Stanard, 962 F.2d 605, 607 (7th Cir. 1992) (urging that courts "decide promptly whether the case should proceed as a representative action, without regard to the virtues of the plaintiffs' legal theory"); In re VISA Check/MasterMoney Antitrust Litig., 192 F.R.D. 68, 79 (E.D.N.Y. 2000) (noting that a court "is not permitted to indulge 'dueling' between opposing experts at the class certification stage"); Or. Laborers-Employers Health \& Welfare Trust Fund v. Philip Morris, Inc., 188 F.R.D. 365, 370, 372 (D. Or. 1998) (quoting the language of Eisen to justify certification of a class without conducting a preliminary inquiry); 7B Charles Alan Wright, Arthur R. Miller \& Mary K. Kane, Federal Practice and PROCEDURE $§ 1785$, at $122-28$ (2d ed. 1986) (acknowledging the impropriety of preliminary hearings on the merits as part of class certifications). In Eisen, the plaintiffs sought a preliminary review to shift notice costs to the defendants and facilitate class certification. 417 U.S. at 178-79. More typically, it is the defendants who would want a preliminary review to oppose class certification.

4. Others have criticized the Eisen rule, but no one has yet offered a thorough analysis. See generally, e.g., Stephen Berry, Ending Substance's Indenture to Procedure: The Imperative for Comprehensive Revision of the Class Damage Action, 80 ColuM. L. REv. 299, 312-15 (1980) 
have weakened the justification even further. The strategic dynamics of the modern class action-and especially the prevalence of settlement-counsel in favor of a rigorous review of the substantive merits and the likelihood of success at the certification stage. Loose certification standards risk high costs by inviting frivolous class action suits that defendants settle rather than face potentially crippling, even bankrupting, damage awards.

Not only is the Eisen rule weakly justified, it is applied unevenly. In some cases, federal judges invoke the rule to ignore merits-related evidence and to facilitate certification. In other cases, judges profess fidelity to the rule while selectively violating it in practice. The result is a patchwork of discretionary decisions difficult to justify on principled grounds.

We argue that there is no sound reason to retain the Eisen rule in its current form. We make two suggestions for reform, one modest and the other more ambitious. Our modest proposal would require district court judges to assess all the competing evidence and evaluate the strength of the case whenever the specific requirements of the federal class action rule, Rule $23,{ }^{5}$ call for an inquiry into meritsrelated factors. ${ }^{6}$ Our more ambitious proposal would require a pre-

(advocating some form of merit review in damage class actions); Geoffrey C. Hazard, Jr., Class Certification Based on Merits of the Claims, 69 TENN. L. REV. (forthcoming 2002) (on file with the Duke Law Journal) (arguing that a precertification inquiry into the merits is consistent with the class action, notwithstanding Eisen, and proposing that a sample of cases be tried before class certification to help the parties value the class claims as a whole); Bartlett H. McGuire, The Death Knell for Eisen: Why the Class Action Analysis Should Include an Assessment of the Merits, 168 F.R.D. 366 (1996) (recommending a preliminary merits review for damage class actions); George L. Priest, Procedural Versus Substantive Controls of Mass Tort Class Actions, 26 J. LEG. STUD. 521 (1997) (criticizing Eisen on the ground that it encourages reliance on procedural controls of mass tort class actions when substantive controls, including a precertification merits review, would be superior); Jack B. Weinstein \& Karin S. Schwartz, Notes from the Cave: Some Problems of Judges in Dealing with Class Action Settlements, 163 F.R.D. 369, 381-82 (1995) (criticizing the Eisen rule as not applicable to preliminary investigations into the merits of a settlement, and emphasizing the importance of a merits review in mass tort settlement class actions).

5. FED. R. CIV. P. 23.

6. To certify a class action under Rule 23 , the class must meet the four requirements set out in Rule 23(a) and also fit within one of the three pigeonholes in Rule 23(b). For a discussion of these certification requirements, see 7A WRIGHT, MILLER \& KANE, supra note 3, §§ 17511780 .

In particular, according to Federal Rule of Civil Procedure 23(a), the class must be "so numerous that joinder of all members is impracticable," FED. R. CIV. P. 23(a)(1); there must be "questions of law or fact common to the class," id. 23(a)(2); the claims of the representative parties must be "typical of the claims ... of the class," id. 23(a)(3); and it must be the case that "the representative parties will fairly and adequately protect the interests of the class," id. 23(a)(4). 
liminary inquiry into the merits in every case, regardless of whether merits-related factors are directly relevant to a specific requirement of Rule 23.

These proposals, which can be implemented by amending Rule 23 , are strongly supported by a careful analysis of the costs and benefits of the certification decision. In many cases, the mere decision to certify creates intense pressure for defendants to settle, and this settlement leverage makes the class action attractive to plaintiffs with frivolous and weak claims. A threshold merits review will help deter this form of class action abuse. Indeed, it also should deter plaintiffs from playing a "shell game," shopping for theories that are especially conducive to class certification but weak on the facts, expecting at the summary judgment or trial stage to switch to stronger theories that never could meet certification requirements.

These four requirements are commonly referred to as numerosity, commonality, typicality, and representational adequacy. 7A WRIGHT, MILLER \& KANE, supra note 3, §§ 1762-1765, at 151, 198, 228, 263.

The class action also must qualify for one of the three subdivisions of Rule 23(b). These three categories identify three different reasons for class action treatment. Focusing on plaintiff classes, which are by far the most common kind of class action and the one that we are concerned about in this article, the Rule 23(b) subdivisions deal with the following situations: First, certification is proper under subdivision 23(b)(1) when separate litigation of individual suits risks imposing especially unfair burdens on the defendant or other class members. Separate adjudications must risk subjecting the defendant to "inconsistent or varying adjudications . . . which would establish incompatible standards of conduct," FED. R. CIV. P. 23(b)(1)(A), or "would as a practical matter be dispositive of the interests of other members not parties . . or substantially impair or impede their ability to protect their interests," $i d .23(\mathrm{~b})(1)(\mathrm{B})$.

Second, certification is proper under subdivision (b)(2) for a class, such as a civil rights class, that seeks class-wide injunctive relief and is therefore homogeneous and cohesive from the remedial point of view. In the language of subdivision 23(b)(2), the defendant must have "acted or refused to act on grounds generally applicable to the class, thereby making appropriate final injunctive relief or corresponding declaratory relief with respect to the class as a whole." Id. 23(b)(2).

Third, certification is proper under subdivision 23(b)(3) when collective adjudication promises substantial efficiency benefits or makes it possible for class members with small claims to bring suit and enforce the substantive law. In the language of subdivision 23(b)(3), the court must find "that the questions of law or fact common to the members of the class predominate over any questions affecting only individual members [(the "predominance requirement")], and that a class action is superior to other available methods for the fair and efficient adjudication of the controversy [(the "superiority requirement")]." Id. 23(b)(3).

Of these 23(a) and 23(b) certification requirements, commonality, typicality, and (b)(3) predominance and superiority most clearly invite a merits-related inquiry, as we discuss below. See infra notes 61-67 and accompanying text. In addition, a merits review is sometimes appropriate when evaluating representational adequacy and the requirements of $(b)(1)(B)$, especially in "limited fund" situations. 
A reexamination of the Eisen rule is timely for a number of reasons. First, in recent months, some federal appellate courts have begun to take a closer look at the rule, and the resulting decisions accentuate a circuit conflict over the rule's scope and its desirability. ${ }^{7}$ For example, a panel of the Seventh Circuit in Szabo v. Bridgeport Machines, Inc., ${ }^{8}$ recently rejected the Eisen rule as a bar to a merits inquiry when the merits are relevant to one of Rule 23's certification requirements, and the Third Circuit seems to be taking a similar approach. ${ }^{9}$ In contrast, the Second Circuit reiterated its support for Eisen in Caridad v. Metro-North Commuter Railroad. ${ }^{10}$ The Caridad court held that the district judge improperly considered competing expert testimony dealing with merits-related issues when he denied certification-even though the testimony was crucial to the viability of the only common questions at issue and even though the appellate court itself admitted to doubts about the truth of the plaintiffs' factual allegations. ${ }^{11}$ The Caridad decision already has had considerable in-

7. Some of these decisions have been made possible by new Rule 23(f), which was added to Rule 23 in 1998. Rule 23(f) authorizes discretionary interlocutory appeals from certification decisions. See FED. R. CIV. P. 23(f), advisory committee's note (1998) (observing that with the adoption of subdivision (f), "[a]ppeal from an order granting or denying class certification is permitted in the sole discretion of the court of appeals"). Prior to Rule 23(f), certification decisions could be appealed only at the end of the case (with very limited exceptions). Coopers \& Lybrand v. Livesay, 437 U.S. 463, 471 (1978). Since most class actions settled soon after certification, few certification decisions ever reached the federal appellate courts. By authorizing discretionary interlocutory appeals, the new Rule 23(f) increases the opportunities for appellate review of traditional class action doctrines such as the Eisen rule. See Michael E. Solimine \& Christine Oliver Hines, Deciding to Decide: Class Action Certification and Interlocutory Review by the United States Courts of Appeals Under Rule 23(f), 41 WM. \& MARY L. REV. 1531, 1537 (2000) (addressing "the appellate courts' new power to grant a discretionary appeal of class certification decisions" under Rule 23(f)).

8. 249 F.3d 672, 675-76 (7th Cir. 2001) (noting that where certification requirements overlap with the merits a judge must make a preliminary inquiry into the merits). The Szabo decision was handed down on May 4, 2001. Id. at 672.

9. See Johnston v. HBO Film Mgmt., Inc., 265 F.3d 178, 185-89 (3d Cir. 2001) (noting the importance of looking beyond the plaintiff's allegations to the underlying evidence to determine predominance); Newton v. Merrill Lynch, Pierce, Fenner \& Smith, Inc., 259 F.3d 154, 167-69 (3d Cir. 2001) (observing that concerns about class actions have become more serious since the Eisen decision and that as a result "a preliminary inquiry into the merits is sometimes necessary to determine whether the alleged claims can be properly resolved as a class action").

10. 191 F.3d 283 (2d Cir. 1999).

11. Id. at 291-93. On remand after reversal, the district judge again denied class certification, this time on the ground that the requirements of Rule 23(b)(2) and (b)(3) were not satisfied. Robinson v. Metro-North Commuter R.R., 197 F.R.D. 85, 88-89 (S.D.N.Y. 2000). The Second Circuit reversed this decision as well. Robinson v. Metro-North Commuter R.R., 267 F.3d 147, 154 (2d Cir. 2001). 
fluence in the lower courts. ${ }^{12}$ Some observers see in these conflicting cases a developing split in the federal circuits, a split that the United States Supreme Court might have to resolve. ${ }^{13}$

In addition to these developments, the Advisory Committee on Civil Rules currently is considering revisions to Rule $23 .{ }^{14}$ As one of its revisions, the Committee should include a provision overturning Eisen and requiring a preliminary merits review at the certification stage. If the recent decisions from the Seventh and Third Circuits signal a broader trend, it is possible that this reform might be implemented without a formal amendment to Rule 23 , at least to the extent of our modest proposal. Nevertheless, the Committee should act to ensure this result. Moreover, it is not clear that federal judges have the power to implement our more ambitious proposal on their own, for a preliminary merits review in all cases might require express authorization in Rule 23. If so, then either the Advisory Committee will have to amend Rule 23, or Congress will have to legislate the change independent of Committee action.

Our analysis also relates to one of the most far-reaching trends in modern procedural law: the growing importance of settlement to the design of procedural rules. ${ }^{15}$ The Eisen case was decided at a time when settlement did not figure as prominently in procedural design as it does today. Over the past three decades, settlement has emerged as a central goal of the federal courts: judges encourage it, procedural

12. At least eight courts in the Second Circuit so far have relied on Caridad to certify classes over the defendant's objection. See infra note 241 (collecting citations). One of those cases is a major antitrust class action involving approximately four million retailers and billions of dollars in damages. In re VISA Check/MasterMoney Antitrust Litig., 192 F.R.D. 68, 79-80 (E.D.N.Y. 2000) (holding, in reliance on Caridad, that conflicting expert testimony cannot be considered at the certification stage, even though critically relevant to class certification issues). The Second Circuit recently affirmed the district judge's certification decision in the VISA Check/MasterMoney case and once again refused to resolve a critical dispute between experts. In re VISA Check/MasterMoney Antitrust Litig., No. 00-7699, 2001 U.S. App. LEXIS 22480, at *18-*19 (2d Cir. Oct. 17, 2001).

13. See Lorna G. Schofield \& Jeffrey S. Jacobson, Circuits Split on Factual Disputes in Class Actions, N.Y.L.J., Oct. 23, 2001, at 1 (wondering whether the Supreme Court will step in to resolve the circuit split).

14. See Federal Rulemaking: Proposed Rules Amendments Published for Comment, at http://www.uscourts.gov/rules/newrules1.html (last visited Feb. 14, 2002) (on file with the Duke Law Journal).

15. For a description of some of these developments, see Judith Resnik, Trial as Error, Jurisdiction as Injury: Transforming the Meaning of Article III, 113 HARV. L. REV. 924, 933-37 (2000) (tying the shifting role of Article III judges to the evolution of the Federal Rules of Civil Procedure). 
rules facilitate it, and scholars write about it extensively. ${ }^{16}$ As we shall see, the significance of the certification decision appears quite different if one looks at the class action as a device for settlement rather than as a mechanism for collective adjudication.

This Article is divided into six Parts. Part I describes the historical background that led up to the Supreme Court's adoption of the Eisen rule in 1974, and Part II summarizes the almost thirty-year history of the rule's application.

Part III takes a critical look at the rule in view of its historical and doctrinal background. It criticizes the Eisen Court's original rationale and examines other efforts to justify the rule. Part III concludes with a careful analysis of the most convincing justification: that the Eisen rule reduces the error cost of mistaken denials of certification and the process cost of expensive evidentiary inquiries at the certification stage. As it turns out, this argument is based on flawed assumptions, and once those assumptions are corrected, it becomes apparent that the cost-benefit balance in fact supports a preliminary review of the merits.

Part IV applies our analysis to a concrete case, Caridad v. MetroNorth Commuter Railroad. This Part explains why the Second Circuit should have allowed a preliminary evaluation of the merits even though doing so required the district judge to review complex expert testimony and technical factual questions. Part IV also illustrates how our proposed alternative would work in practice.

Part V is a brief discussion of our more ambitious proposal. The discussion is brief because the analysis is already presented in previous Parts. The error- and process-cost arguments developed in Part III have implications beyond the certification standards of the current

16. See Marc Galanter \& Mia Cahill, "Most Cases Settle”: Judicial Promotion and Regulation of Settlements, 46 STAN. L. REV. 1339, 1340-46 (positing that, "[o]ver the past five decades, first state and then federal judges have embraced active promotion of settlement as a major component of the judicial role"); Resnik, supra note 15, at 927-28 \& n.11, 947-49, 995 (noting the judicial commitment to promoting settlement, and observing that, "[a]s an educational and rulemaking organization, the federal judiciary has adopted an anti-adjudication and prosettlement agenda"). In recent decades, court-annexed alternative dispute resolution has become an important tool for encouraging settlement. See Edward F. Sherman, The Impact on Litigation Strategy of Integrating Alternative Dispute Resolution into the Pretrial Process, 168 F.R.D. 75, 75-77 (1996) (focusing on the possible procedural compatibility of alternative dispute resolution and trials). In 1998, Congress adopted the Alternative Dispute Resolution Act, 105 Pub. L. No. 105-315, 112 Stat. 2993 (1998) (codified at 28 U.S.C. $§ \S 651-658$ (2000)), which requires each federal district to furnish an alternative dispute resolution process (such as mediation, early neutral evaluation, or mini-trial), $i d$. $33(\mathrm{~b}), 112$ Stat. at 2994 , and requires the parties in every case at least to consider using the process provided, $i d$. $\$ 4(\mathrm{a}), 112$ Stat. at 2994. 
Rule 23. A careful balance of the costs and benefits of the Eisen rule strongly suggests the desirability of reforming class action law to require a merits review as a separate and independent condition of certification in all cases.

\section{HISTORICAL AND DOCTRINAL BACKGROUND}

\section{A. Birth of the Certification Procedure}

Rule 23, the federal class action rule, was adopted in $1938^{17}$ and almost completely revised in $1966 .{ }^{18}$ The original version was highly formalistic. It linked class treatment to the abstract character of the legal rights at stake. A class action was permissible when the rights alleged were "joint," "common," or "secondary," but not when they were "several" unless united by a "common question" and "common relief." 19

The 1966 revision of Rule 23 eliminated the focus on rights and adopted a more pragmatic approach. The new rule recognized four functional reasons for class treatment: to prevent serious litigationrelated unfairness to the defendant or class members, ${ }^{20}$ to assure re-

17. See 7A Wright, Miller \& KANE, supra note 3 , § 1752, at 15 (summarizing class actions under the original Rule 23).

18. See id. $\S 1753$, at 41 (summarizing changes to Rule 23 in 1966).

19. The 1938 version of Rule 23 read in relevant part:

(a) Representation. If persons constituting a class are so numerous as to make it impracticable to bring them all before the court, such of them, one or more, as will fairly insure the adequate representation of all may, on behalf of all, sue or be sued, when the character of the right sought to be enforced for or against the class is

(1) joint, or common, or secondary in the sense that the owner of a primary right refuses to enforce that right and a member of the class thereby becomes entitled to enforce it;

(2) several, and the object of the action is the adjudication of claims which do or may affect specific property involved in the action; or

(3) several, and there is a common question of law or fact affecting the several rights and a common relief is sought.

Id. $\S 1753$, at 5 n.1.

20. See FED. R. CIV. P. 23(b)(1):

(1) the prosecution of separate actions by or against individual members of the class would create a risk of

(A) inconsistent or varying adjudications with respect to individual members of the class which would establish incompatible standards of conduct for the party opposing the class, or

(B) adjudications with respect to individual members of the class which would as a practical matter be dispositive of the interests of the other members 
medial efficacy, ${ }^{21}$ to aid in substantive law enforcement, ${ }^{22}$ and to promote litigation efficiency. ${ }^{23}$ The shift to a pragmatic approach opened up new possibilities for the class action and led to greatly expanded use of the device. For example, the 1966 drafters created a novel type of class action in subdivision (b)(3), the purpose of which was to further the twin policies of efficiency and substantive norm enforcement. $^{24}$

not parties to the adjudications or substantially impair or impede their ability to protect their interests.

An example of (b)(1)(A) is a case in which the defendant might face inconsistent injunctive orders issuing from different courts if individual class members were allowed to sue separately. An example of $(b)(1)(B)$ is a case in which the defendant has insufficient funds to satisfy all the individual judgments, so some class members would receive no recovery at all if class members litigated separately. See generally 7A WRIGHT, MILLER \& KANE, supra note 3, §§ 1772-1774 (reviewing ways in which separate claims might adversely affect class members or the opposing party).

21. See FED. R. CIV. P. 23(b)(2):

(2) the party opposing the class has acted or refused to act on grounds generally applicable to the class, thereby making appropriate final injunctive relief or corresponding declaratory relief with respect to the class as a whole.

The most commonly cited example of a (b)(2) class action is a civil rights case asking for broad class-wide injunctive relief, where class status is meant to assist the court in crafting an effective remedy. See generally 7A WRIGHT, MILLER \& KANE, supra note 3, §§ 1775-1776 (noting the applicability of this subsection to civil rights cases).

22. See FED. R. CIV. P. 23(b)(3):

(3) the court finds that the questions of law or fact common to the members of the class predominate over any questions affecting only individual members, and that a class action is superior to other available methods for the fair and efficient adjudication of the controversy. The matters pertinent to the findings include: (A) the interest of members of the class in individually controlling the prosecution or defense of separate actions; (B) the extent and nature of any litigation concerning the controversy already commenced by or against members of the class; (C) the desirability or undesirability of concentrating the litigation of the claims in the particular forum; (D) the difficulties likely to be encountered in the management of a class action.

This provision mainly covers damage actions that do not involve the sort of unfairness concerns that trigger Rule 23(b)(1). There are two paradigmatic situations that fall under Rule 23(b)(3). One is a case like securities fraud and antitrust, in which individual claims are too small to justify separate suits and in which without a class action the substantive law would be underenforced. In these cases, the class action facilitates aggregation of all the small claims into a single whole that has large enough damages to attract competent class counsel. The second paradigm for Rule 23(b)(3) is a case like a mass tort, in which most plaintiffs have large individual claims but the claims have many overlapping legal and factual issues. The class action in these cases primarily serves efficiency goals by avoiding duplicative litigation of the common issues. See generally 7A WRIGHT, MILLER \& KANE, supra note 3, §§ 1777-1780 (discussing the different types of, reasons for, and requirements for (b)(3) class actions).

23. See supra note 22 (acknowledging the import of efficiency).

24. See generally 7A WRIGHT, MILLER \& KANE, supra note 3, § 1777 (discussing the purpose and background of 23(b)(3)). 
These changes focused attention on the certification stage. Prior to 1966 , Rule 23 made no explicit reference to certification at all. ${ }^{25} \mathrm{Al}-$ though subdivision (a) of Rule 23 specified conditions for a class action, nothing in the 1938 Rule expressly required any kind of formal certification procedure. ${ }^{26}$ Moreover, the rights typology of Rule 23(a), in theory at least, required only an inspection of the formal legal structure of the suit and not an inquiry into the facts. ${ }^{27}$

The 1966 revision of Rule 23 took a different approach and in so doing turned certification into a critical stage of class action litigation. Whereas class actions under the 1938 version of Rule 23 did not always bind absent class members, ${ }^{28}$ class actions under the 1966 revi-

25. See 3B J. Moore \& J. Kennedy, Moore's Federal Practice II 23.50, at 23-884.4 (2d ed. 1996) (noting that the original Rule 23 had no counterpart to current subdivision (c)(1), which requires a formal certification decision).

26. See Robert G. Bone, Personal and Impersonal Litigative Forms: Reconceiving the History of Adjudicative Representation, 70 B.U. L. REV. 213, 284 (1990) (reviewing STEPHEN C. Yeazell, From Medieval Group Litigation to the Modern Class Action (1987)) (acknowledging that before 1966, a judge usually had occasion to make a determination of certification only if the defendant raised an objection to plaintiff's failure to join class members as necessary parties).

27. See John G. Harkins, Jr., Comment, Federal Rule 23-The Early Years, 39 ARIz. L. REV. 705, 709 (1997) (embracing the notion that the determination of membership in the class and adequacy of representation were relatively straightforward for (a)(1) and (a)(2) class actions under the 1938 version of Rule 23). Significantly, the nineteenth- and early-twentiethcentury precedent, on which the rule drafters relied, largely presumed adequate representation. See Annotation, Right to Control of Class Suit, 91 A.L.R. 587, 587-88 (1933) (demonstrating that representational adequacy was put in question only with specific evidence of bad faith); see also Bone, supra note 26, at 285 (describing the absolute dominion view of representative litigation, which meant that the represented party had unilateral decisionmaking power). However, the formal rights categories created some confusion in practical application. See, e.g., ZeChARIAH CHAFFEE, JR., SOME PROBLEMS OF EQUiTy 244-73 (1950) (decrying the finite and exclusive list of remedies available under Rule 23 for narrowing the applicability of the rule).

28. Nothing in the text of original Rule 23 referred to res judicata. Moreover, a key architect of the rule, James William Moore, advocated res judicata effect only for some class actions. See James William Moore \& Marcus Cohn, Federal Class Actions-Jurisdiction and Effect of Judgment, 32 U. ILL. L. REV. 555, 556-62 (1938) (postulating that res judicata applies only in limited cases, including public rights suits). For much of its history, the class action-or "representative suit" as it was called prior to 1938 - was conceived not as a device to bind absentees, but as a way to permit an individual suit to go forward over the objection that necessary parties had not been joined. Bone, supra note 26 , at $243-84$. Whether the absent parties also would be bound by the judgment rendered in the individual suit depended on the law of res judicata and was not an automatic consequence of a properly brought class action. Id. at 257-84. Eventually, courts and commentators began to link class action doctrine to the res judicata rules, and with this linkage the class action gradually came to be seen as a binding device. Id. at 279-82. Still, not all class actions produced binding judgments. The 1938 version of Rule 23 embodied this mixed scheme-the Rule itself reserved judgment on preclusive effects and courts recognized preclusion only in some situations. Id. at 289 n.180. 
sion were all meant to have full res judicata effect. The 1966 Rule drafters made perfectly clear-and for the first time-that the entire point of the class action procedure was to adjudicate individual claims in one proceeding with full binding effect on each and every class member. ${ }^{29}$

Firmly linking the class action to res judicata in this way dramatically increased the stakes for absent class members and placed greater responsibility on the judge and more weight on the certification process. With res judicata at stake from the beginning of the suit, it became especially important to make sure that the case satisfied the requirements for class treatment. Accordingly, the 1966 Rule drafters included an express provision in Rule 23(c)(1) establishing a formal certification procedure: the judge had to determine "[a]s soon as practicable after commencement of an action brought as a class action" whether the suit is to be maintained as such. ${ }^{30}$

Over the years since 1966, the certification decision has taken on great strategic importance. For the class attorney, certification can mean the difference between a huge fee and no fee at all. Even in relatively routine cases, class attorneys earn hundreds of thousands, and frequently millions, of dollars in fees. ${ }^{31}$ For class members, a favorable certification decision can mean greater litigating power and enhanced settlement leverage. And, for the defendant, certification can mean the difference between facing a massive and essentially

29. FED. R. CIV. P. 23, advisory committee's note, subdivision (c)(3) (1966); 7B WRIGHT, MILLER \& KANE, supra note $3, \S 1789$, at 246. Still, a court cannot prejudge res judicata effect. A later court in a suit by an absentee class member is free to reject the res judicata effect of the earlier class action because of some defect in the way the class action was handled. See id. $\S 1789$, at 244-47.

30. FED. R. CIV. P. 23(c)(1).

31. A Federal Judicial Center study of class actions in four federal districts found mean fee awards in excess of one million dollars in three of the four districts studied and a mean of $\$ 732,537$ in the fourth district. THOMAS E. WILlgING ET AL., EMPIRICAL STUDY OF ClASS

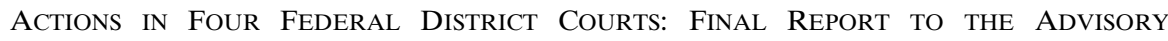
COMMITTEE ON CIVIL RULES 148 fig. 69 (1996) (reporting additionally that median fee awards in the four districts were $\$ 667,500 ; \$ 660,000 ; \$ 959,901$; and $\$ 1,500,000)$. Although an extreme example, many class attorneys in the state tobacco cases earned tens of millions of dollars in fees. For example, Kurzweil v. Philip Morris Cos., No. 94 Civ. 2373, No. 94 Civ. 2546, 1999 U.S. Dist. LEXIS 18378, at $* 8$ (S.D.N.Y. Nov. 30, 1999), a class action alleging securities fraud through the concealment of nicotine's addictiveness, generated $\$ 37.1$ million in attorneys' fees. \$37.1 Million in Fees Ok'd in Securities Case, Mealey's Attorney FeEs, Dec. 1999. Ramos v. Philip Morris Cos., 743 So. 2d 24, 32-33 (Fla. Ct. App. 1999), a class action on behalf of flight attendants alleging harm from second-hand smoke, generated $\$ 46$ million in attorneys' fees and $\$ 3$ million in costs. Florida Appeals Court Affirms Settlement in Broin Class Action, TOBACCO INDUSTRY LITIG. REP., Apr. 9, 1999, at 7. 
uninsurable liability risk in one suit or a more manageable series of risks in individual suits. ${ }^{32}$ Because the strategic implications are so substantial, parties today invest a great deal in litigating certification motions. ${ }^{33}$

\section{B. Early Confrontation with the Merits Issue}

The 1966 revision of Rule 23 led to heightened concerns about frivolous class action litigation, especially in connection with the novel damages class action authorized by subdivision (b)(3). ${ }^{34}$ In the 1970s, Congress adopted legislation that expanded the availability of consumer class actions under (b)(3). ${ }^{35}$ This development, coupled with use of the (b)(3) class action in antitrust, securities, and environmental cases, prompted industry complaints about the mounting burdens of class litigation and particularly about frivolous class action suits. $^{36}$

At least one judge responded to these concerns by screening the merits at the certification stage. In Dolgow v. Anderson, ${ }^{37}$ Judge Weinstein refused to certify a class unless the plaintiffs could show, after limited discovery and a preliminary review of the evidence, that

32. We examine these points in some detail in Part III.D.

33. See Willging ET AL., supra note 31, at 8-9, 36-39 (presenting data on certification disputes). Many of Rule 23's requirements are sufficiently open-ended to invite a great deal of adversarial conflict at the certification stage, especially in cases with high stakes. For example, Rule 23(a)(3)'s typicality requirement asks a court to engage in the necessarily imprecise task of determining whether the claims of the representative parties arise from the same event or conduct and are based on the same legal theory as those of the class. E.g., In re American Med. Sys., Inc., 75 F.3d 1069, 1082 (6th Cir. 1996). Also, Rule 23(a)(4)'s adequacy-of-representation requirement calls for an inquiry into possible conflicts of interest between the class and class representatives or class counsel, issues over which parties can sharply disagree. Furthermore, a court applying Rule 23(b) must make discretionary determinations about such things as the existence of a limited fund under (b)(1)(B) and the predominance of common questions and superiority of the class action under (b)(3). See, e.g., In re Telectronics Pacing Sys., Inc., 172 F.R.D. 271, 285-86 (S.D. Ohio 1997) (examining the application of 23(b)(1)(B) to a subclass seeking a medical monitoring remedy).

34. See Deborah R. Hensler et Al., Class Action Dilemmas: Pursuing Public GOALS FOR PRIVATE GAIN 15-16 (2000) (acknowledging a history of criticism of Rule 23(b)(3)).

35. Id. at 16-17. For example, the Truth in Lending Act, 15 U.S.C. $\S \S 1601-1667$ e (2000), was amended in 1976 to take account of the special problems raised by class actions under that statute. See generally William E. Knepper, The Superiority Requirement of Rule 23(b)(3) in Class Actions Under the Truth in Lending Act, 37 OHIO ST. L.J. 291 (1976) (tracing the litigation spurred by the Truth in Lending Act and the 1996 amendment to Rule 23).

36. For an account of these events and the heated controversy that ensued after the 1966 revision, see HENSLER ET AL., supra note 34, at 15-20.

37. 43 F.R.D. 472 (E.D.N.Y. 1968). 
the class claims had a significant chance of succeeding at trial. ${ }^{38}$ However, not everyone was happy with the screening approach. Some judges objected on the grounds that there was no express authorization in the language of Rule 23 and that an early merits determination might prejudice the losing party's chances later in the case. ${ }^{39}$

\section{The Eisen Decision}

The United States Supreme Court faced the screening issue in Eisen v. Carlisle \& Jacquelin..$^{40}$ The Eisen case alleged violations of the antitrust and securities laws and was brought against securities brokers on behalf of a class of approximately six million odd lot traders on the New York Stock Exchange. ${ }^{41}$ Most class members had too little at stake to justify an individual suit. Thus, the class action was the only practical means to obtain a private remedy for everyone. ${ }^{42}$

The trial judge, concerned that individual notice to all class members would be too costly given the small claims, devised a novel procedure for allocating notice costs. ${ }^{43} \mathrm{He}$ held a preliminary hearing on the merits and, on the strength of a favorable merits review, allocated ninety percent of the notice costs to the defendants. ${ }^{44}$ The Court of Appeals reversed, ${ }^{45}$ and the Supreme Court affirmed the Court of Appeals, holding that the trial judge had no authority to undertake a preliminary inquiry into the merits at the certification stage. ${ }^{46}$

The Supreme Court justified its holding on three grounds. First, and most important, the Court reasoned that Rule 23 did not clearly

38. Id. at 501 (embracing the potential efficiency gains of a preliminary hearing, and decrying the potential harm to the defendant from an erroneous certification decision, including the adverse effect of class notice and the strong settlement pressure of a certified class action).

39. In the same year that Judge Weinstein endorsed a merits review, Judge Metzner of the Southern District of New York rejected it. See Mersay v. First Republic Corp., 43 F.R.D. 465, 469 (S.D.N.Y. 1968) (noting concerns about the effect of a premature merits determination and reservations about the scope of judicial power to engage in early factual inquiries); accord Miller v. Mackey Int'l, Inc., 452 F.2d 424, 427-30 (5th Cir. 1971).

40. 417 U.S. 156 (1974).

41. Id. at 166.

42. See id. at 161 ("Economic reality dictates that petitioner's suit proceed as a class action or not at all.").

43. Rule 23(c)(2) requires "individual notice to all [class] members who can be identified through reasonable effort" in a (b)(3) class action. FED. R. CIV. P. 23(c)(2).

44. Eisen v. Carlisle \& Jacquelin, 54 F.R.D. 565, 567 (S.D.N.Y. 1972).

45. Eisen v. Carlisle \& Jacquelin, 479 F.2d 1005, 1008 (2d Cir. 1973).

46. Eisen, 417 U.S. at 177. 
authorize a preliminary merits review. ${ }^{47}$ Moreover, the delay involved in holding a hearing was inconsistent with Rule 23(c)(1)'s requirement that the certification decision be made "[a]s soon as practicable after the commencement of [the] action." ${ }^{48}$ Second, the Court worried about potential prejudice from a determination made without the usual trial safeguards, which might "color the subsequent proceedings and place an unfair burden on the defendant." pressed concern that a preliminary evaluation would give the representative plaintiffs the benefit of a class action-a determination of the merits of the class claims-before they established the requirements for certification. ${ }^{50}$

The Court did not limit its holding to the unusual facts of the case, in which the plaintiffs sought and the defendants opposed the preliminary merits review. Instead, it used expansive and seemingly categorical language that has had a profound effect on class action practice ever since:

We find nothing in either the language or history of Rule 23 that gives a court any authority to conduct a preliminary inquiry into the merits of a suit in order to determine whether it may be maintained as a class action. Indeed, such a procedure contravenes the Rule.... ${ }^{51}$

\section{Evaluating THE Merits After EISEN}

Eisen quickly came to stand for a general rule prohibiting any preliminary investigation of the merits at the certification stage. ${ }^{52}$ Courts applied this rule across the board, not just to cases like Eisen in which an investigation benefited the plaintiff class by allowing notice costs to be shifted, but also, and much more frequently, to cases in which an investigation would benefit the defendant by screening

\footnotetext{
47. Id. at 178 .

48. Id. (quoting FED. R. CIV. P. 23(c)(1)).

49. Id. at 177 .

50. See id. at 178-79 (holding that the plaintiff must pay the cost of notice as part of his burden).

51. Id. at 177 .

52. See, e.g., Blackie v. Barrack, 524 F.2d 891, 901 \& n.17 (9th Cir. 1975) (holding that the Court cannot hold a preliminary hearing into the merits, that the judge must accept plaintiffs' allegations as true, and that the fact that the plaintiffs might not be able to prove allegations is not a ground for denying certification).
} 
out frivolous or weak class action suits. ${ }^{53}$ Even today, almost thirty years after the decision, courts commonly cite Eisen for a general rule barring a preliminary merits inquiry and requiring a certification analysis focused on allegations rather than evidence. ${ }^{54}$

This simple statement of the Eisen rule, however, does not accurately reflect the way the substantive merits figure in certification decisions today. In fact, judges sometimes do probe behind the allegations and examine supporting evidence to determine whether Rule 23's requirements are satisfied. ${ }^{55}$ The Supreme Court even endorsed this practice in its 1982 decision, General Telephone Co. of the Southwest v. Falcon ${ }^{56}$ discussed in Section A. Eisen, however, continues to be strong precedent and has produced a large body of case law in which lower court judges stop short of making the sort of merits inquiry required for a sound certification analysis.

53. As the cases discussed in this Part illustrate, the Eisen rule is used today to avoid inquiring into the merits in connection with decisions to certify a class. See infra Part II.B.

54. See, e.g., Koch v. Stanard, 962 F.2d 605, 607 (7th Cir. 1992) (noting that the trial judge must accept the allegations of the complaint as true when deciding whether certification is appropriate); Shelter Realty Corp. v. Allied Maint. Corp., 574 F.2d 656, 661 n.15 (2d Cir. 1978) (same); Kupfer v. Goodman, No. CV-97-3894, 2000 U.S. Dist. LEXIS 7951, at*6 (E.D.N.Y. May 17, 2000) ("Courts must accept the allegations in the complaint as true and should avoid preliminary inquiry into the merits of the case."); In re Great S. Life Ins. Co. Sales Practices Litig., 192 F.R.D. 212, 215 (N.D. Tex. 2000) ("[T]he court presumes the truth of Plaintiffs' allegations for the purposes of this opinion ....") (citations omitted); Alexander v. Q.T.S. Corp., No. 98-C3234, 1999 U.S. Dist. LEXIS 11842, at *10 (N.D. Ill. July 30, 1999) ("For purposes of determining certification, allegations made in the complaint are taken as true and the merits of the claim are not considered."); Medine v. Wash. Mut., FA, 185 F.R.D. 366, 369 (S.D. Fla. 1998) ("The court takes the factual allegations stated in the complaint as true ...."). These principles are also combined in some cases with the additional observation that doubts should be resolved in favor of certification, especially as the judge has power to decertify later in the suit if facts show certification was improvidently granted. See, e.g., In re Sch. Asbestos Litig., 789 F.2d 996, 1011 (3d Cir. 1996) (discussing the manageability of the class, and stressing that "certification is conditional" and that "[w]hen, and if, the district court is convinced that the litigation cannot be managed, decertification is proper"); Council of \& for the Blind of Del. County Valley, Inc. v. Regan, 709 F.2d 1521, 1546 n.58 (D.C. Cir. 1983) (holding that "[b]etter it is, in any sort of case, to utilize class certification liberally when suit-dismissals would chance the loss of a meritorious claim forever," because the court can amend the certification order later); Barnes v. Am. Tobacco Co., 176 F.R.D. 479, 493 (E.D. Pa. 1997) (“[E]ven though this case may present a close question as to whether this action should be certified under Rule 23(b)(2), the Court will grant certification because the Court may amend the certification order before a decision on the merits ...."); 7B WRIGHT, MILLER \& KANE, supra note 3, § 1785, at 128-31 (noting that the power to decertify has "encouraged many courts to be quite liberal in certifying a class . . . at an early stage").

55. See, e.g., In re Unioil Sec. Litig., 107 F.R.D. 615, 618 (C.D. Cal. 1985) (noting that the court may consider evidence relevant to the requirements of Rule 23 even though that evidence also may relate to the merits of the case).

56. 457 U.S. 147 (1982). 


\section{A. The Falcon Decision}

General Telephone Co. of the Southwest v. Falcon was an employment discrimination suit brought by a Mexican-American employee of General Telephone. ${ }^{57}$ Alleging racial discrimination, the plaintiff sought to represent a class consisting of employees like himself who were denied promotion, as well as applicants for employment who were not hired. ${ }^{58}$ The plaintiff argued that his allegation of racial discrimination in promotion was enough to support an acrossthe-board attack on all of General Telephone's discriminatory practices, including those practices, such as hiring, that did not affect him personally.

The Supreme Court rejected this argument. The Court held that the commonality and typicality prongs of Rule 23(a) require more than a mere allegation of racial discrimination. ${ }^{59}$ They require some common thread connecting the otherwise distinct discriminatory practices, for example, a single tainted policy or biased testing procedure that affects hiring and promotion in similar ways. ${ }^{60}$ Without the common thread, a class consisting of employees denied promotion and applicants denied employment would not have sufficient unity to proceed as a litigating entity. As a result, promotion discrimination and hiring discrimination would have to be challenged in separate class action suits.

In the Court's view, trial judges are supposed to do a "rigorous" analysis of each of Rule 23's certification requirements. ${ }^{61}$ The judge should not merely accept the plaintiff's allegation that the Rule is satisfied; nor in a case like Falcon should she presume commonality and typicality based simply on an allegation of discrimination. Rule 23 requires a much more intensive certification inquiry:

The District Court's error in this case ... is the failure to evaluate carefully the legitimacy of the named plaintiff's plea that he is a proper class representative under Rule 23(a). As we noted in Coopers \& Lybrand $v$. Livesay "the class determination generally involves considerations that are 'enmeshed in the factual and legal is-

\footnotetext{
57. Id. at 149.

58. Id. at 151 .

59. Id. at 157 .

60. See id. at 158-59 \& n.15 (holding that the district court erred in presuming that the plaintiff's claim was typical of other claims without identifying common questions of law or fact).

61. Id. at 161.
} 
sues comprising the plaintiff's cause of action." Sometimes the issues are plain enough from the pleadings to determine whether the interests of the absent parties are fairly encompassed within the named plaintiff's claim, and sometimes it may be necessary for the court to probe behind the pleadings before coming to rest on the certification question .... [W] reiterate today that a Title VII class action, like any other class action, may only be certified if the trial court is satisfied, after a rigorous analysis, that the prerequisites of Rule 23(a) have been satisfied. ${ }^{62}$

\section{B. Post-Falcon Case Law}

Ever since Falcon, the federal courts have struggled to chart a middle course between Falcon's requirement of a rigorous analysis and Eisen's prohibition of a preliminary inquiry into the merits. ${ }^{63}$ The task is particularly difficult because of the close relationship between the reasons for class action treatment and the substantive character of the case. ${ }^{64}$ The certification requirements of Rule 23 force the judge to think about how the lawsuit will unfold-what substantive issues will be important and how much of the litigation those issues will consume.

Consider the Rule 23(b)(3) class action. The primary reason for (b)(3) certification when class members have large claims is the efficiency of adjudicating common questions in a single proceeding. ${ }^{65}$ The

62. Id. at 160-61 (citations omitted).

63. See, e.g., Retired Chi. Police Ass'n v. City of Chi., 7 F.3d 584, 599 (7th Cir. 1993) (cautioning against a preliminary merits inquiry, the court observed that "[w]e have noted that the 'boundary between a class determination and the merits may not always be easily discernible'") (quoting Eggleston v. Chi. Journeyman Plumbers' Local Union No. 130, 657 F.2d 890, 895 (7th Cir. 1981)); Sirota v. Solitron Devices, Inc., 673 F.2d 566, 571-72 (2d Cir. 1982) (noting that courts, when deciding certification, can make "very basic" merits determinations, but should not resolve "substantial questions of fact going to the merits"); Krueger v. N.Y. Tel. Co., 163 F.R.D. 433, 438 (S.D.N.Y. 1995) ("The Court should not resolve any material factual disputes in the process of determining whether plaintiffs have provided a reasonable basis for their assertions.”) (citation omitted); MANUAL FOR COMPLEX LITIGATION (THIRD) §§ 30.11-.13 (1995) (noting that the court might need to go beyond the pleadings and allow limited discovery into the merits to evaluate certification requirements such as typicality, but that it should not "assess the merits of the underlying claim(s)").

64. See Stastny v. S. Bell Tel. \& Tel. Co., 628 F.2d 267, 274-75 (4th Cir. 1980) (noting the close "[i]ntertwining of class action inquiry with merits inquiry," especially for Title VII class actions, and also noting the resulting dilemma facing trial courts in making "a fair determination of class action status in advance of trial on the merits," a problem "for which no happy general solution has yet been, or is likely to be, found").

65. See 7A Wright, Miller \& KANE, supra note 3, § 1777, at 517 (noting the role that Rule 23(b)(3) serves in promoting economy). 
two requirements of (b)(3) reflect this purpose: first, common questions must predominate over individual questions, and second, the class action must be superior to the other available methods for the fair and efficient adjudication of the controversy. These two requirements, however, depend upon predictions about the future course of the lawsuit, and these predictions in turn depend upon assessments, explicit or implicit, of the relative salience of substantive issues and supporting evidence. ${ }^{66}$

To assess predominance, for instance, a judge has to determine which common questions are serious subjects for litigation and how much of the litigation will be devoted to resolving them. So too she must predict which individual questions will loom large, how important they will be, and how much time and energy will be devoted to litigating them. Indeed, if judges were not willing to inquire into the merits, parties would have wide latitude to inject frivolous issues to bolster or undermine a finding of predominance. Plaintiffs, for example, might allege numerous common questions, while defendants would allege defenses that introduce as many individual issues as possible. $^{67}$

Thus, judges must predict the likely litigation track of the class action. But in keeping with Eisen, they must do so without weighing the evidence or predicting likelihood of success. ${ }^{68}$ It is not at all clear

66. See Szabo v. Bridgeport Machs., Inc., 249 F.3d 672, 676 (7th Cir. 2001) (noting that where "some of the considerations under Rule 23(b)(3) [such as the manageability factor for superiority] overlap the merits . . . then the judge must make a preliminary inquiry into the merits"); Waste Mgmt. Holdings, Inc. v. Mowbray, 208 F.3d 288, 298 (1st Cir. 2000) ("Eisen, fairly read, does not foreclose consideration of the probable course of the litigation at the class certification stage."); Walco Invs., Inc. v. Thenen, 168 F.R.D. 315, 329-30 (S.D. Fla. 1996) (discussing the "evolving nature of the Eisen doctrine" in the Eleventh Circuit, and holding that it is proper to examine the evidence to determine whether predominance is satisfied but not to determine whether plaintiffs have a meritorious claim). The same thing is true for Rule 23's other certification requirements, including commonality, typicality, and at times adequacy of representation.

67. See Mowbray, 208 F.3d at 298 ("We are unwilling to fault a district court for not permitting arguments woven entirely out of gossamer strands of speculation and surmise to tip the decisional scales in a class certification ruling."); cf. Eggleston, 657 F.2d at 895 (stressing the importance of a careful district court review, given the parties', and especially the defendant's, incentives to manipulate the court's determination of the certification issues).

68. See In re Polypropylene Carpet Antitrust Litig., 178 F.R.D. 603, 618 (N.D. Ga. 1997) (" $[\mathrm{T}]$ he Court examines evidence as to how the class proponents intend to prevail at trial, not whether the facts adduced by the class proponents are susceptible to challenges by class opponents.") (citation omitted); Gibbs Props. Corp. v. Cigna Corp., 196 F.R.D. 430, 434 (M.D. Fla. 2000) (same); Leszczynski v. Allianz Ins., 176 F.R.D. 659, 675 (S.D. Fla. 1997) (noting that the 
how this can be done. Judges might try to extrapolate from past experience adjudicating cases of the same general type, but this is bound to be an extremely crude approach. Not only does it reward the strategic pleading of frivolous issues-a special problem for the federal courts' liberal notice pleading regime ${ }^{69}$-but it also ignores factors specific to particular cases. Because party strategy is quite sensitive to facts and evidence, case-specific variations can have a large impact on how cases are litigated and thus on which claims and issues turn out to be substantial enough to survive the pretrial stage and become a major part of the trial.

Not surprisingly, the resulting dilemma ${ }^{70}$ has produced a rather muddled body of case law. Courts disagree about how closely they can examine evidence and scrutinize the factual merits at the certification stage. ${ }^{71}$ Sometimes the certification determination can be made without the need to probe too deeply. For example, relatively clear evidence might show sufficient factual heterogeneity to justify denial of certification. In Reilly v. Gould, Inc., ${ }^{72}$ a case involving lead seepage

court must look beyond the complaint to determine whether individual issues will predominate, but in doing so should not evaluate plaintiffs' likelihood of success on the claims).

69. See Leatherman v. Tarrant County Narcotics Intelligence \& Coordination Unit, 507 U.S. 163, 164 (1993) (rejecting the Fifth Circuit's application of a heightened pleading system in civil rights cases alleging municipal liability under 42 U.S.C. § 1983); Conley v. Gibson, 355 U.S. 41, 47-48 (1957) (holding that a detailed statement of facts is not required under the Federal Rules of Civil Procedure).

70. See Stastny v. S. Bell Tel. \& Tel. Co., 628 F.2d 267, 274-75 (4th Cir. 1980) (referring to the "dilemma" created by Eisen).

71. Purely legal decisions concerning the scope of the substantive law are not particularly troubling under Eisen as long as the judge accepts all the factual allegations as true. See, e.g., Gibbs Props. Corp., 196 F.R.D. at 438-39 (assuming that it is proper to determine at certification whether individual reliance can be presumed as a legal matter on a RICO mail fraud claim). Indeed, judges routinely make these sorts of decisions when deciding motions to dismiss for failure to state a claim. Cf. Szabo, 249 F.3d at 675-76 (noting that courts that accept all the factual allegations as true are treating the certification determination as if it were a Rule 12(b)(6) motion to dismiss for failure to state a claim).

Trial judges apparently are willing to entertain motions for summary judgment prior to deciding on certification - even though doing so has been criticized as inconsistent with a strict reading of Eisen. See, e.g., Wright v. Schock, 742 F.2d 541, 543-44 (9th Cir. 1984) ("Under the proper circumstances-where it is more practicable to do so and where the parties will not suffer significant prejudice-the district court has discretion to rule on a motion for summary judgment before it decides the certification issue."); WILLGING ET AL., supra note 31, at 29-31 (noting that, although appeals courts disagree on the appropriateness of ruling on dispositive motions prior to certification, district judges routinely do so). Some commentators have linked judicial willingness to consider precertification dispositive motions to judicial discontent with the Eisen rule. See, e.g., McGuire, supra note 4, at 385, 387-90. In any event, this approach to merits screening is limited to those relatively rare cases suitable for early summary judgment.

72. 965 F. Supp. 588 (M.D. Pa. 1997). 
from a contaminated site, the trial judge relied on government reports, a database of information about class members, and depositions of plaintiffs and expert witnesses to determine that individual factual issues of exposure and causation would dominate the litigation and thus preclude a finding of predominance under (b)(3). ${ }^{73}$ Along the way, the judge had to evaluate the merits of the plaintiffs' factual arguments, ${ }^{74}$ but the evidence was clear enough to make the task relatively easy.

The more controversial cases are those in which the balance between commonality and individuality is much closer and the evidence more difficult to evaluate. For example, (a)(2) commonality and (a)(3) typicality might pivot on a single common question of fact, such as the existence of a central policy or practice that the plaintiff alleges produces company-wide discriminatory effects. If the defendant challenges the plaintiff's evidence on this common question, the trial judge must decide how closely to examine the merits. So too, if the defendant injects an affirmative defense that turns on individual facts, and the plaintiffs argue that the defense is baseless, the judge once again must decide how deeply to probe the merits of the defense.

Judges deal with these hard cases in different ways, and it is not always clear what factors influence the different approaches. Some judges simply accept the plaintiff's allegations and evidence no matter how weak, often citing Eisen without any further explanation. ${ }^{75}$ Others look at the facts more critically. ${ }^{76}$ How critically seems to depend

73. Id. at 601-05.

74. See id. at 597 (assuming that lots of factors would be important to determining causation); $i d$. at 600 (assuming that not all plaintiffs would succeed on the medical monitoring claim).

75. See 7B WRIGHT, MILLER \& KANE, supra note 3, § 1781, at 7-8 (noting that courts are willing to certify a class on a minimal showing, whenever the assertion of class status is "at least colorable"); see also Or. Laborers-Employers Health \& Welfare Trust Fund v. Philip Morris, Inc., 188 F.R.D. 365, 370 (D. Or. 1998) (relying on Eisen as reason not to inquire at all into the merits or to require a trial plan, even though the court expressed doubt about the viability of the common questions).

76. See Szabo, 249 F.3d at 675-76 (criticizing the district judge for applying a Rule 12(b)(6) standard to the certification decision, and holding that a preliminary merits inquiry was necessary); Waste Mgmt. Holdings, Inc. v. Mowbray, 208 F.3d 288, 298 (1st Cir. 2000) (finding that the district court properly discounted an individualized waiver defense on the ground that it was not likely to survive summary judgment, and noting that "a district court must formulate some prediction as to how specific issues will play out in order to determine whether common or individual issues predominate in a given case"); Retired Chi. Police Ass'n v. City of Chi., 7 F.3d 584, 599 (7th Cir. 1993) (holding that the district court did not engage in an impermissible examination of the merits when it, among other things, discounted the plaintiffs' allegation of uniform communications). 
in part on the complexity of the issue. The more difficult the task, the less likely it is that the judge will carefully probe the evidence.

For example, judges are reluctant to delve into disputes over complex technical issues or scientific and statistical evidence, at least when doing so requires weighing competing testimony or evidentiary claims. In Caridad v. Metro-North Commuter Railroad, ${ }^{77}$ an employment discrimination case in which experts disagreed about the relevance of certain statistical evidence crucial to a finding of commonality, the Second Circuit adopted a general rule against resolving disputes between "dueling experts" at the certification stage. ${ }^{78}$ And it did so at the same time that it expressed reservations about the Caridad plaintiffs' ultimate chance of success. ${ }^{79}$ While Caridad is unusual in formulating a general rule, it is not unusual in its reluctance to weigh evidence regarding complex issues at the certification stage. ${ }^{80}$

Another factor that appears to affect willingness to probe the merits has to do with the judge's prior beliefs about the value of the class action. Judges seem more willing to overlook evidentiary weaknesses and certify a class the more strongly they believe in the importance of the class action for enforcement of the substantive law. This tendency is most evident in small-claim class actions, such as those based on securities fraud, antitrust violations, or consumer protection statutes. When plaintiffs have small claims, the class action is often their only practical means to obtain legal relief, and judges favorably disposed to using the class action in these cases tolerate a consider-

77. 191 F.3d 283 (2d Cir. 1999). For an in-depth discussion of Caridad, see infra Part IV.

78. Caridad, 191 F.3d at 293 (holding that a court should not delve into the merits of an expert's opinion or resolve disputes between dueling experts at the certification stage); see also In re VISA Check/MasterMoney Antitrust Litig., 192 F.R.D. 68, 79 (E.D.N.Y. 2000) (same), aff'd, No. 00-7699, 2001 U.S. App. LEXIS 22480 (2d Cir. Oct. 17, 2001).

79. Caridad, 191 F.3d at 291 (noting that it might be "extremely difficult" for plaintiffs to prove their case). For a discussion of the fate of the named plaintiffs' suits in the aftermath of Caridad that strongly suggests that many of the cases were dubious, see infra Parts IV.D-E.

80. On the other hand, some courts have been willing to examine evidence, even statistical evidence, to deny certification in cases in which the defects or inadequacies in the proffered evidence were patent. See, e.g., Chaffin v. Rheem Mfg. Corp., 904 F.2d 1269, 1275-76 (8th Cir. 1990) (affirming a denial of certification in a Title VII case in which the plaintiffs' statistical and anecdotal evidence was extremely thin-"too bareboned"-and inconsistent with other clear data); Sheehan v. Purolator, Inc., 839 F.2d 99, 102-04 (2d Cir. 1988) (affirming a denial of certification where the plaintiffs' regression analysis omitted obviously crucial variables and there was little anecdotal evidence of discrimination); Gilchrist v. Bolger, 733 F.2d 1551, 1555-56 (11th Cir. 1984) (affirming a denial of certification where the plaintiff offered unanalyzed statistics with obvious flaws). 
able degree of uncertainty in the plaintiffs' legal theories at the certification stage. ${ }^{81}$

One of the clearest examples of this trend is the securities fraud class action, especially securities fraud actions that rely on a fraud-onthe-market theory to establish commonality and predominance. The fraud-on-the-market theory converts materiality, reliance, and damages into common questions and makes it easier for representative plaintiffs to meet the predominance requirement of Rule 23(b)(3). The theory derives from the efficient capital market hypothesis, which holds that the market price for securities reflects all material information, including any public misrepresentations that have wrongfully inflated the price of the company's stock. ${ }^{82}$ As a result, anyone who buys or sells shares on the open market can be presumed, by virtue of relying on the market price, also to have relied on the misrepresentations and suffered damage as a proximate result.

Although the fraud-on-the-market theory makes it easier to show predominance, it also can exacerbate intraclass conflicts and make it more difficult to satisfy the Rule 23(a)(4) adequacy of representation requirement. ${ }^{83}$ One district court squarely confronted this problem in In re Seagate Technology II Securities Litigation. ${ }^{84}$ In so

81. See, e.g., Gary Plastic Packaging Corp. v. Merrill Lynch, Pierce, Fenner \& Smith, Inc., 903 F.2d 176, 179 (2d Cir. 1990) ("In light of the importance of the class action device in securities fraud suits, these [Rule 23] factors are to be construed liberally.") (citation omitted); In re VISA Check/MasterMoney Antitrust Litig., 192 F.R.D 68, 88 (E.D.N.Y. 2000) (certifying a class action in an antitrust case despite substantial doubts about the plaintiffs' ability to prove injury on a classwide basis, and observing that without class certification, "millions of small merchants will lose any practical means of obtaining damages"); In re Lease Oil Antitrust Litig., 186 F.R.D. 403, 419, 424-25, 429 (S.D. Tex. 1999) (evaluating potential intraclass conflicts and representational adequacy in a settlement class action, but refusing, in light of Eisen, to probe the strength of the subclass claims, and noting that all doubts should be resolved in favor of certifying an antitrust class action because of its important role in private enforcement).

82. See Basic, Inc. v. Levinson, 485 U.S. 224, 247 (1988) (recognizing a rebuttable presumption based on the fraud-on-the-market theory for Rule 10b-5 actions).

83. For example, suppose plaintiffs complain that the defendant artificially inflated the price of its stock through misrepresentations. E.g., In re Seagate Tech. II Sec. Litig., 843 F. Supp. 1341, 1344 (N.D. Cal. 1994). A plaintiff who bought stock on a particular date and later sold it has an incentive to maximize the degree of price inflation at the date of purchase to maximize the amount of his loss and thus his damages. By contrast, a plaintiff who sold stock on the same date benefits from minimizing price inflation on that date. Id. at 1359-62. Moreover, plaintiffs who still hold stock at the time of suit have an interest in limiting the amount of damages to keep the company profitable, whereas plaintiffs who have sold all their shares have an interest in maximizing damages even if doing so cripples the company. Id. at 1362-64.

84. 843 F. Supp. 1341 (N.D. Cal. 1994); see also O’Neil v. Appel, 165 F.R.D. 479, 494-95, 496-98 (W.D. Mich. 1996) (denying class certification due to intraclass conflicts, and holding 
doing, the judge expressly noted the connection between judicial attitudes toward class action policy and liberality at the certification stage. In particular, he attributed the tendency of previous courts to downplay intraclass conflicts to "an overarching desire to effectuate the securities laws and provide relief to small-claim plaintiffs." 85

The Seagate court adopted a stricter approach and held that an evidentiary hearing was necessary to inquire into potential conflicts. Since any such hearing would have to probe merits-related factors, such as the level of price inflation and trading volumes, ${ }^{86}$ the judge had to deal with the Eisen rule. He pointed out that Eisen was decided before judicial recognition of the fraud-on-the-market theory and argued that proper application of Rule 23's requirements necessitated a preliminary merits determination on the facts of the Seagate case. $^{87}$

Subsequent judicial responses to Seagate have been mixed, partly because of differing attitudes toward class action policy. ${ }^{88}$ Those judges who refuse to follow Seagate's lead seem driven in part by the same concerns that the Seagate court identified in the precedent it examined. They are inclined to overlook conflicts and avoid examining the merits out of concern that the predominance requirement, if taken seriously, would scuttle the class action as a device for enforcing the securities laws and vindicating small claims. ${ }^{89}$

that Eisen does not bar a hearing on the merits to determine the availability of a fraud-on-themarket theory for Rule 23(b)(3) predominance).

85. Seagate, 843 F. Supp. at 1359.

86. Id. at 1366 .

87. Id. at 1367. In fact, a hearing never was held because the plaintiffs responded to the Seagate opinion by narrowing the class definition to eliminate the potential conflicts. In re Seagate Tech. II Sec. Litig., 156 F.R.D. 229, 230 (N.D. Cal. 1994).

88. See, e.g., Picard Chem. Inc. Profit Sharing Plan v. Perrigo Co., Nos. 1:95-CV-141, 1:95CV-290, 1996 U.S. Dist. LEXIS 16330, at *24*27 (W.D. Mich. Sept. 27, 1996) (collecting cases on both sides and concluding that the majority still certify fraud-on-the-market class actions in spite of Seagate's conflicts concerns).

89. See, e.g., In re Gaming Lottery Sec. Litig., 58 F. Supp. 2d 62, 69-71 (S.D.N.Y. 1999) (noting that "[t]he position of the Seagate court is most decidedly the minority position" and that the Second Circuit has made clear that the Rule 23 requirements should be construed liberally in securities fraud suits); In re Intelligent Elecs., Inc. Sec. Litig., No. 92-1905, 1996 U.S. Dist. LEXIS 1713, at *14-*15 (E.D. Pa. Feb. 13, 1996) (rejecting Seagate's conflicts analysis, and stating that it "would prohibit the use of the class action mechanism in the vast majority of securities fraud actions," which would be "an anomalous result, particularly in the Third Circuit, where class actions are considered particularly well-suited to securities fraud cases"); Yamner v. Boich, No. C-92-20597RPA, 1994 U.S. Dist. LEXIS 20849, at*6-*7, *19-*21 (N.D. Cal. Sept. 15, 1994) (rejecting Seagate's approach to conflicts and at the same time stressing the importance of liberally construing the certification requirements to enable federal securities actions). 
Mass tort litigation is another area in which beliefs about the costs and benefits of class litigation affect judicial willingness to probe the merits. But in these cases the effect goes the other way. Concerned about the extreme settlement pressure of mass tort class actions, a few courts have denied certification on merits-related grounds. One of the most notable examples is In re Rhone-Poulenc Rorer, Inc., ${ }^{90}$ a suit brought by AIDS-infected hemophiliacs against companies supplying allegedly tainted blood products. ${ }^{91}$ The Seventh Circuit Court of Appeals reversed the district court's certification of a class in part because defendants had won most of the individual suits previously litigated. ${ }^{92}$ In the court's view, certifying a class in a case that appeared so weak on the merits gave too much power to the plaintiffs. ${ }^{93}$ It was better for individual cases to proceed separately so the merits could be tested with a larger sample of verdicts.

In sum, the Eisen rule is no longer, if it ever was, an absolute obstacle to a preliminary review of the merits. ${ }^{95}$ Yet it still stands in the

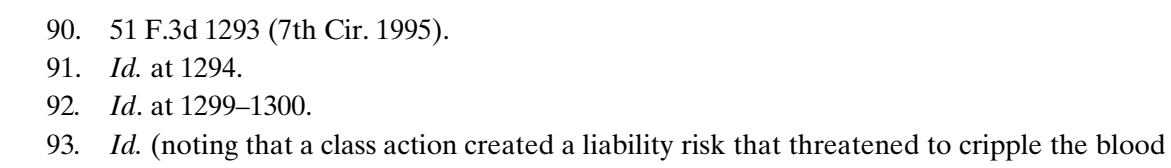
products industry); see also Castano v. Am. Tobacco Co., 84 F.3d 734, 749-50 (5th Cir. 1996) (denying certification on the ground that more experience with individual suits was necessary for the court to do an informed predominance and superiority analysis under Rule 23(b)(3), because individual suits will help the court, among other things, determine the importance of common questions for trial and identify the most salient claims and issues). But see In re Copley Pharm., Inc., 161 F.R.D. 456, 461 (D. Wyo. 1995) (criticizing Rhone-Poulenc for refusing to certify a class, and noting that Rhone-Poulenc's merits-based analysis violates the Eisen rule).

94. See Rhone-Poulenc, 51 F.3d at 1299-1300 (noting "the pattern that results will reflect a consensus, or at least a pooling of judgment, of many different tribunals"); see also In re VISA Check/MasterMoney Antitrust Litig., No. 00-7699, 2001 U.S. App. LEXIS 22480, at *58-*72 (2d Cir. Oct. 17, 2001) (Jacobs, J., dissenting) (arguing that the district judge's conditional certification was erroneous, and stressing the enormous settlement pressure that certification gives plaintiffs and the high likelihood that a certified class action never would be tried on the merits); Szabo v. Bridgeport Machs., Inc., 249 F.3d 672, 675, 676-77 (7th Cir. 2001) (stressing both the settlement pressure imposed on the defendant by a "bet-your-company" class action and the need for a preliminary merits inquiry to make the Rule 23(b)(3) certification determinations).

95. There are two other, rather special, situations in which courts conduct a merits review at the certification stage. One involves certification of a "limited fund" class action under Rule 23(b)(1)(B). Rule 23(b)(1)(B) authorizes a class action when the assets of the defendant are too limited to satisfy all the expected damage awards. Under these circumstances, case-by-case litigation can leave some injured parties without any meaningful recovery. A class action helps ensure that the limited fund is distributed fairly among all class members. To determine whether a defendant's assets in fact constitute a limited fund, however, the court must estimate the likelihood of success on the merits and the probable recovery in the average case. Accordingly, a merits review is normally part of the certification process. See, e.g., In re Sch. Asbestos Litig., 789 F.2d 996, 1005 (3d Cir. 1986) (vacating the certification of a Rule 23(b)(1)(B) nationwide 
way of the kind of serious merits inquiry that class certification requires. Moreover, it has spawned an incoherent body of certification decisions. When a court believes it is important to probe the merits, it will make an effort to distinguish Eisen, if possible. On the other hand, when, as is all too common, a court wishes to avoid a careful certification analysis-because, for example, the evidence is complex or the benefits of class treatment are perceived to be substantial-it need only cite Eisen to support its result. This kind of ad hoc-indeed post hoc-process of justification is especially problematic in the class action setting where certification has a potentially serious impact on settlement dynamics. For this reason, it is important to reexamine the Eisen rule and its underlying rationale. To this task we now turn.

\section{A CRITICAl ANALYSIS OF THE EISEN RULE}

Several commentators have criticized the Eisen rule, ${ }^{96}$ and the Advisory Committee on Civil Rules has on occasion considered, though never approved, proposals to eliminate it. ${ }^{97}$ Yet Eisen's de-

mandatory class for punitive damages because "neither the record nor the court's findings are adequate to support the procedure," while recognizing the "inherent limitations of any factual inquiry undertaken at such an early stage of the litigation").

The second situation involves the settlement class action. In a settlement class action, plaintiffs and defendants agree to a settlement before filing suit. They file a class action to obtain court approval under Rule 23(e) so that the settlement will bind all class members. Because settlement and certification are inextricably intertwined in these cases, the judge normally reviews the terms of the settlement at the same time as she certifies the class. And reviewing the settlement normally involves some kind of evaluation of the class plaintiffs' likelihood of success on the merits. As a result, the structure of the settlement class action happens to locate the merits review at the same stage as the certification decision. See, e.g., In re Gen. Motors Corp. Pick-Up Truck Fuel Tank Prods. Liab. Litig., 55 F.3d 768, 805 (3d Cir. 1995) (discussing "the special difficulties the court encounters with its duties under Rule 23(e) in approving settlements where negotiations occur before the court has certified the class").

96. See Berry, supra note 4, at 312-14 ("A preliminary hearing on the merits prior to entry of a certification order is potentially the most effective technique for managing massive class actions, but this device was foreclosed by the Supreme Court's decision in Eisen v. Carlisle \& Jacquelin . . . ."); McGuire, supra note 4, at 370-81 (arguing that in claims for monetary relief, courts should be free to conduct a preliminary assessment of the merits in deciding whether to certify a class); Priest, supra note 4, at 570-73 (stressing that, although "[i]n an ideal world, Rule 23 might be amended to overrule Eisen," Eisen can be read to allow "some substantial range" of precertification merits review); Weinstein \& Schwartz, supra note 4, at 369-70 \& n.3 (cautioning against an "unnecessary extension" of the dictum in Eisen that would unnecessarily "prevent consideration of the merits for other purposes before certification").

97. See, e.g., Willging ET AL., supra note 31, at 101-10 app. B (reproducing a November 1995 draft of a proposed revision of Rule 23 considered by the Advisory Committee, which in subdivision (b)(3)(E) authorizes an inquiry into the merits); see also Berry, supra note 4, at 314 n.91 (listing authorities favoring a preliminary merits review as of 1980). See generally HENSLER 
fenders cite a number of reasons to support the rule. The Eisen Court itself relied on the language of Rule 23(c)(1) and on the importance of avoiding prejudice from an early merits decision. ${ }^{98}$ Some defenders also stress the value of keeping the certification decision as a purely procedural inquiry free of entanglement with substance. ${ }^{99}$ Still others point to the risk of erroneous certification denials and the high cost of undertaking a complicated factual inquiry at an early stage. ${ }^{100}$

The following analysis first describes in somewhat more detail our proposed alternative to the Eisen rule, and then considers in turn each of the reasons offered in support of Eisen, evaluating them in light of the advantages of the alternative approach.

\section{A. The Alternative: Reviewing the Merits at Certification}

The Eisen rule cannot possibly preclude consideration of the purely legal elements of the plaintiffs' substantive claim or the facts as they are alleged in the complaint, for otherwise there would be no way to identify common questions, assess typicality, or evaluate the other certification requirements. The controversy centers on whether courts should be allowed to probe behind the factual allegations, examine the evidence, and consider the strength of class issues and claims. ${ }^{101}$ The Eisen rule, strictly construed, bars this approach. ${ }^{102}$ Our proposal requires it.

ET AL., supra note 34, at 28-37 (reviewing the history of proposals to revise Rule 23, including the addition of a merits review to the certification inquiry).

98. Eisen v. Carlisle \& Jacquelin, 417 U.S. 156, 177-78 (1974) (“Additionally, we might note that a preliminary determination of the merits may result in substantial prejudice to a defendant, since of necessity it is not accompanied by the traditional rules and procedures applicable to civil trials.").

99. See, e.g., McCray v. Standard Oil Co., 76 F.R.D. 490, 495 (N.D. Ill. 1977) (noting that courts should resolve certification issues before deciding a motion directed to the merits "to preserve the purely procedural character" of the certification decision).

100. For the process-cost argument, see Arthur R. Miller, Of Frankenstein Monsters and Shining Knights: Myth, Reality, and the "Class Action Problem," 92 HaRV. L. REV. 664, 689 (1979) ("It would be extremely naïve to believe that lawyers would not transform the enormous energy now devoted to the certification question under rule 23(c)(1) to [the precertification merit review] context ....").

101. Compare Shelter Realty Corp. v. Allied Maint. Corp., 574 F.2d 656, 661 n.15 (2d Cir. 1978) (noting that it is proper to accept allegations of the complaint as true when deciding class certification), with Szabo v. Bridgeport Machs., Inc., 249 F.3d 672, 676 (7th Cir. 2001) (rejecting the view espoused in Shelter Realty, and holding that judges may probe allegations and evidence relating to the merits when necessary to evaluate Rule 23's certification requirements).

102. See supra note 63 and accompanying text. 
In the modest form of our proposal, the trial judge would review the evidence and determine whether the legal and factual issues on which the parties rely to support (or oppose) commonality, typicality, predominance, and other Rule 23 certification requirements are in fact viable. If an issue is not viable, it would be ignored in the certification analysis. In addition, the judge would consider evidence, not just allegations, when mapping the path of the lawsuit and predicting which issues - those common to the class or specific to individual class members-are likely to consume the bulk of litigation time and resources. Finally, the judge in our proposal would weigh the evidence on both sides - not only evidence supporting the plaintiffs' prima facie case, but also the defendant's rebuttal evidence and, when relevant, any evidence relating to affirmative defenses.

Under our more ambitious proposal, the judge would conduct the same evidentiary review, but that review would not be limited to Rule 23's certification requirements. Instead, the judge would make a general assessment of the strength of the plaintiffs' case as a whole and certify a class only if the case met a threshold "likelihood of success" standard.

Neither our modest nor our ambitious proposal requires a minitrial on the merits or full-blown factual and expert discovery. Rather, the trial judge must give the merits issues some attention and evaluate whether they are viable under a standard that would give the plaintiffs some benefit of the doubt, but not a free pass. Again, the objective is to weed out frivolous claims and unfounded class action allegations so they do not form an improper basis for class certification. We discuss the standard in more detail below.

This focus on evidence means that the parties must have access to precertification discovery, although that discovery should be strictly limited in duration and scope to contain costs at the certification stage and control strategic abuse. ${ }^{103}$ The idea is to provide an op-

103. Courts that have inquired into the merits usually do so after some opportunity for discovery. See, e.g., Szabo, 249 F.3d at 676 (opining that "[b]efore deciding whether to allow a case to proceed as a class action ... a judge should make whatever factual and legal inquiries are necessary under Rule 23," including receiving evidence and holding hearings). Furthermore, some courts currently use a similar approach in analogous areas, allowing only limited preliminary discovery in connection with early determinations of qualified immunity in $\S 1983$ cases. See, e.g., Crawford-El v. Britton, 93 F.3d 813, 819-21 (D.C. Cir. 1996) (noting that the rule barring discovery in regard to illicit motivation does not bar limited discovery concerning a defendant official's state of mind for other purposes); Karen M. Blum, Heightened Pleading: Is There Life After Leatherman?, 44 CATH. U. L. REV. 59, 92-95 (1994) (arguing for limited discovery in qualified immunity cases where a defendant's state of mind is crucial to the underlying substan- 
portunity for the parties to conduct core discovery-one or two rounds of document requests and a few depositions limited to key witnesses probably would be sufficient in most cases. Of course, if plaintiffs base class certification on complicated theories that need to be supported with detailed factual evidence, then more discovery might be warranted. To be sure, early merits determinations, even those limited to a threshold likelihood of success standard, can be less accurate than determinations made after full discovery and on a complete evidentiary record. However, the increased error risk must be balanced against the errors that are generated currently by certifications that ignore the merits altogether-a point we develop in more depth in Section D.

It is also important that the judge make all merits evaluations explicitly and justify each of them by reference to the evidence. For example, if plaintiffs allege that a defendant's discriminatory practices have a single company-wide source, the trial judge would have to weigh the evidence on both sides of the issue and make an explicit determination whether the allegation is sufficiently viable to support a finding of commonality and typicality and to warrant certification under either the modest or ambitious proposal.

Nevertheless, all we would require is that the issue or the case as a whole meet a threshold level of likelihood of success. It is not necessary that the merits be strong or important enough that the benefits of class treatment exceed the costs in the specific case. ${ }^{104}$ Our proposed likelihood of success standard would be similar to the one judges now use for evaluating preliminary injunction motions, but perhaps not quite as stringent. ${ }^{105}$ This choice of standard has a number of advan-

tive claim and the facts pertaining to that state of mind are "peculiarly within the control of the defendant"). Also, courts routinely decide preliminary injunction motions on a limited evidentiary record—even though preliminary injunction determinations are almost always followed by settlement and even though the judge's decision shapes relative bargaining power and thus the outcome of the case.

104. Cf. HENSLER ET AL., supra note 34, at 473-76 (discussing problems with a case-specific, cost-benefit certification standard, including the possibility of judicial bias based upon the judge's personal attitude and social beliefs). Admittedly, any element added to the certification analysis, especially one that gives judges greater power to deny certification, is likely to evoke controversy both at the stage of adoption and at the stage of application. This is, however, a poor reason, standing alone, to reject an otherwise sensible reform.

105. See 13 James Wm. Moore et AL., Moore's Federal Practice $§ 65.22$ (3d ed. 1997) (stating that, in seeking a preliminary injunction, the moving party must show likelihood of success on the merits). This is not the only possible choice, of course. Other options include a simple "nonfrivolous" test or something closer to a summary judgment test. See McGuire, supra note 4, at 397 (recommending a "substantial possibility of success" standard); Miller, supra note 
tages. Judges are accustomed to applying it in the preliminary injunction setting. Moreover, the standard is designed in part to balance the error costs from granting and denying preliminary injunctive relief, just as our proposed merits review is designed to balance error costs from granting and denying certification. ${ }^{106}$ In addition, the likelihood of success test performs a similar gatekeeping function as our proposed merits review does for certification. In both situations, trial judges can use the test to avoid conferring settlement leverage on plaintiffs in weak cases. ${ }^{107}$ Finally, the likelihood of success standard has the virtue of flexibility; it allows the judge in appropriate cases to adjust the threshold to differences in false grant and false denial error costs. $^{108}$

\section{B. The Eisen Court's Rationale: Rule 23's Language and Risk of Prejudice}

As we saw above, ${ }^{109}$ the Eisen Court read the language of subdivision (c)(1) of Rule 23 to require a prompt certification decision that ruled out a time-consuming inquiry into the merits. In fact, however, 23(c)(1) requires no such thing. The Rule does not provide a precise timetable for certification; it simply instructs the trial judge to make the certification decision "[a]s soon as practicable after the commencement of [the] action." What is "practicable" within the meaning of 23(c)(1) depends on what the certification requirements of Rule 23(a) and (b) demand. ${ }^{11}$

General Telephone Co. of the Southwest v. Falcon ${ }^{111}$ recognized this point. The Falcon Court held that Rule 23 demanded a rigorous

100 , at $689 \&$ nn.109-10 (criticizing the use of a proposed "serious question" test). Whatever the standard, however, the trial judge's task is the same: she must evaluate the evidence with regard to each issue and determine whether the evidence meets the standard.

106. See infra Part III.D.

107. A favorable decision on a preliminary injunction motion, like a favorable certification decision, creates considerable settlement leverage and frequently leads to a settlement. See Jean O. Lanjouw \& Josh Lerner, Tilting the Table? The Use of Preliminary Injunctions, 44 J.L. \& ECON. 573, 601 (2001) (asserting that the plaintiff's option to seek preliminary injunctive relief provides "a particularly effective threat to use against capital-constrained defendants").

108. See 11A Charles Alan Wright, Arthur R. Miller \& Mary K. Kane, Federal PRACTICE AND PROCEDURE $§ 2948.3$, at 195 (2d ed. 1995) (describing the sliding scale for deciding preliminary injunction motions).

109. See supra Part I.C.

110. See 7B WRIGHT, MiLler \& KANE, supra note 3, § 1785, at 96 (noting that "[t]he time at which the court finds it 'practicable' to make a class action determination may vary with the circumstances of the particular case").

111. 457 U.S. 147 (1982). For a discussion of Falcon, see supra Part II.A. 
certification analysis. ${ }^{112}$ Insofar as a rigorous analysis requires an inquiry into the merits, the certification decision must await that inquiry. Under those circumstances, it is not "practicable" to make the decision more quickly.

Understood in this way, 23(c)(1) does not impose an independent constraint on the timing of certification or the scope of a meritsrelated inquiry. Its purpose is simply to assure that the judge attends to the certification decision promptly rather than postponing it until later in the suit. Indeed, as part of the certification process today, courts allow limited discovery and indulge rather extensive and timeconsuming argument—all without running afoul of 23(c)(1). ${ }^{113}$

The Eisen Court also noted the possible prejudice that might result from a preliminary determination of the merits in the absence of the usual trial safeguards. ${ }^{114}$ In particular, the Court worried that "tentative findings" might "color the subsequent proceedings" and "place an unfair burden on the defendant." 115 In Eisen, it was the plaintiff who sought the preliminary determination and the defendant who faced possible prejudice. ${ }^{116}$ These roles are reversed in most class action cases, in which the defendant questions the merits and the plaintiff stands to suffer prejudice by a premature review. Yet the Eisen Court's argument can apply to both situations: if certification is denied, the plaintiff's individual case might be affected adversely by a preliminary merits review; if certification is granted, the defendant might be prejudiced in opposing the class.

Regardless of which party is affected, the argument based on prejudice is seriously flawed. Whatever prejudice might result is not

\footnotetext{
112. 457 U.S. at 161.
}

113. See 7B Wright, Miller \& KANE, supra note 3, § 1785, at 107-10 (noting that some courts may allow precertification discovery if "useful" or "necessary"). See generally WILLGING ET AL., supra note 31, at 8-9, 36-39 (reporting that "[j]udges ruled on motions to certify within median times of 2.8 months to 8.5 months after the date of the motion" and describing the range of disputed issues in contests over class certification).

114. Eisen v. Carlisle \& Jacquelin, 417 U.S. 156, 178 (1974). The Court also seemed troubled by the prospect of a class representative obtaining the benefits of a merits determination without first satisfying the requirements for certification. Id. at 177-78. This is a puzzling concern. After all, a class representative benefits only if the class is certified; otherwise, a tentative and provisional determination is not particularly helpful to him in adjudicating his individual case. Moreover, insofar as Rule 23's certification requirements call for an inquiry into the merits, such an inquiry cannot give plaintiffs more of a benefit than they are entitled to receive under Rule 23. But see Priest, supra note 4, at 572-73 (interpreting this language creatively as a way to distinguish Eisen and permit a precertification merits review to screen unmeritorious suits).

115. 417 U.S. at 178.

116. Id. at $177-78$. 
sufficient to justify Eisen's blanket prohibition. Similar risks attend the grant of a preliminary injunction, which also requires a preliminary evaluation of the merits. ${ }^{117}$ To be sure, the preliminary injunction is a well-established equitable remedy, but so too is the class action. ${ }^{118}$ Moreover, the argument from prejudice overlooks the fact that a judge is always formulating tentative opinions about the merits as a case progresses and relying on those informal opinions to manage the suit. ${ }^{119}$ Admittedly, it might be somewhat harder for a judge to keep an open mind when the determination is formal, even if it is also supposed to be tentative and provisional. That result is not necessarily objectionable, though, since a formal, systematic, and public determination is likely to be more accurate than an informal one and thus more worthy of reliance.

Although the Eisen Court did not mention it, one also must consider the effect of an early merits determination on settlement incentives. We consider this factor as part of an error-cost analysis in Section D. But first we must deal with a different sort of objection.

\section{The Substance/Procedure Dichotomy and the Federal Rules Scheme}

Those who believe that procedure should be limited to strictly technical matters dealing exclusively with the conduct of litigation might object that an early merits review involves the court too deeply in the substance of a lawsuit. ${ }^{120}$ It is difficult to know how to respond to this sort of objection because its formalistic quality obscures its underlying logic. Insofar as the argument assumes that it is possible to mark a sharp divide between procedure and substance, it ignores de-

\footnotetext{
117. See supra note 105 .

118. See generally YEAZELL, supra note 26; Bone, supra note 26, at 257-304 (tracing equitable jurisdiction over representative suits from the eighteenth and nineteenth centuries to the modern class device).

119. See Weinstein \& Schwartz, supra note 4, at 382 (asserting that in managing class actions a judge is "constantly considering merits-related issues" to "fulfill his or her obligations under Rule 16").

120. It is worth mentioning that a certification rule authorizing a merits review would not "abridge, enlarge, or modify any substantive right" in violation of the Rules Enabling Act, 28 U.S.C. $\S 2072$ (b) (1994). For if it did, we would have to worry about Rule 56 (summary judgment) and Rule 11 (sanctions for frivolous suits) as well.
} 
cades of judicial frustration grappling with the procedure/substance dichotomy in a variety of procedural settings. ${ }^{121}$

Nevertheless, it is true that procedural rules seldom rely explicitly on an assessment of the evidentiary merits. Motions to dismiss for failure to state a claim test the legal sufficiency of a case, but they do so without probing the evidence or questioning the factual allegations. Moreover, pleading rules, party and claim joinder rules, and discovery rules make no explicit reference to evidentiary factors.

Some procedural rules, however, contemplate a merits review, at least in some cases. ${ }^{122}$ Summary judgment is the most obvious example. Ever since the Supreme Court expanded the use of summary judgment in $1986,{ }^{123}$ lower courts have examined the sufficiency of the plaintiff's evidence with some care to screen frivolous and weak cases. Furthermore, courts evaluate the merits, at least in a preliminary way, when substantive issues are relevant to threshold questions like personal jurisdiction. ${ }^{124}$ Given these examples, it would be a mistake to believe that the current system completely insulates its procedural rules from a substantive review. When such a review makes sense as a policy matter, the rules allow it.

121. The most famous example, of course, is the line of cases applying the Erie doctrine. See Erie R.R. Co. v. Tompkins, 304 U.S. 64, 78-80 (1938) (holding that in diversity cases, federal courts should follow the substantive law of the state in which they sit).

122. And judges implicitly consider the merits of the various issues when they decide how to manage the litigation. See Weinstein \& Schwartz, supra note 4, at 382 ("The fact that formal merits pronouncements are rare ... in ... the pretrial process ... does not mean that the judge never considers the merits ... . The dynamics of litigation require a continually changing hypothesis about the merits.").

123. Three cases decided by the Supreme Court in its 1986 term-the so-called Celotex trilogy-expanded the use of summary judgment as a screening device. See Celotex Corp. v. Catrett, 477 U.S. 317, 325 (1986) (holding that a moving party may obtain summary judgment by showing an absence of evidence in support of the nonmovant's case); Anderson v. Liberty Lobby, Inc., 477 U.S. 242, 257 (1986) (holding that the trial burden of persuasion should be incorporated into the standard for determining whether to grant summary judgment); Matsushita Elec. Indus. Co. v. Zenith Radio Corp., 475 U.S. 574, 587 (1986) (holding that the nonmoving party must do "more than simply show that there is some metaphysical doubt as to the material facts").

124. See Szabo v. Bridgeport Machs., Inc., 249 F.3d 672, 676-77 (7th Cir. 2001) (noting that preliminary inquiries into the merits are routinely made in connection with subject matter and personal jurisdiction motions under Rule 12(b)(1) and 12(b)(6)). In addition, Rule 26(b)(2)(iii) authorizes a judge to refuse additional discovery if he determines that "the burden or expense of the proposed discovery outweighs its likely benefit." FED. R. CIV. P. 26(b)(2)(iii). When making such a determination, the judge must evaluate, if only implicitly, the sufficiency of current evidence in light of the evidence sought in order to determine the value of additional discovery. 
Still, the procedural system seems to favor postponing a serious evidentiary review until after substantial discovery has been completed. Summary judgment, for example, usually takes place only after the parties have had ample opportunity to uncover information and evidence. ${ }^{125}$ Indeed, the original drafters of the Federal Rules of Civil Procedure implemented a preference for deciding cases on the facts and evidence rather than on technicalities, and as a result they relaxed pleading requirements and broadened discovery. ${ }^{126}$

One might argue from this preference that an early merits review conflicts with the basic scheme of the Federal Rules because it bars class litigation before the parties have had a chance to develop the evidence fully. The trouble with an early merits review, according to this objection, is not that it is unreliable or too costly-we address those arguments in Sections D and E-but instead that it is incompatible with the intent of those who drafted the class action rule and inconsistent with the basic structure of the Federal Rules scheme. ${ }^{127}$

This objection fails for a number of reasons. For one thing, denial of certification is simply not the same as a final dismissal. It does not prevent the plaintiffs from conducting discovery and trying their claims; they remain free to continue with individual suits, conduct discovery, and investigate the facts. ${ }^{128}$ It is true that a denial of certifica-

125. See FED. R. CIV. P. 56(f) (stating that a court may refuse or continue a summary judgment motion to permit affidavits or depositions to be taken or other methods of discovery to be had).

126. This was a constant theme of Charles Clark, the reporter to the original advisory committee and the main architect of the Federal Rules. See, e.g., Charles Clark, The Handmaid of Justice, 23 WASH. U. L.Q. 297, 308-20 (1938) (discussing the advantages of notice pleading and the importance of deciding cases on the merits).

127. Cf. Leatherman v. Tarrant County Narcotics Intelligence \& Coordination Unit, 507 U.S. 163, 168 (1993) (striking down a Fifth Circuit rule requiring strict pleading in civil rights cases-which had been designed to screen frivolous suits—on the basis that the rule conflicted with the Federal Rules' notice pleading scheme).

128. Moreover, it seems unlikely that the original drafters of the Federal Rules would have been terribly concerned in 1938 about creating obstacles to class suits. Historically, the class action fits only awkwardly into a world dominated by individual litigation, see YEAZELL, supra note 26, at 220 (discussing how early Justices recognizing group litigation grappled with "such intangibles as American strains of individualism"), and the original Rule 23 narrowly confined the device to traditional rights-based categories, see Bone, supra note 26, at 286 (stating that rather than litigating on behalf of class members, a representative party was an advocate of a rights-based interest in which all class members shared). The 1966 Rule drafters expanded the class action, but they also imposed restrictive certification requirements. See HENSLER ET AL., supra note 34, at 12-15 (explaining that, while "maintain[ing] the tripartite structure of the 1938 Rule, the committee rewrote the requirements for each type of class action"). When a rigorous application of those requirements calls for an inquiry into the evidentiary merits, doing so cannot be inconsistent with the drafters' intent. 
tion, as a practical matter, can quell all hope of further litigation when class members have claims too small to justify individual suits. However, it is not the denial of certification that prevents plaintiffs from suing; it is the fact that litigation is costly. This does not mean that one should be unconcerned about the effect of an early merits review on the availability of small-claim class actions. Rather, it means that any such concern must be addressed as a straightforward policy matter, not as a matter of the drafters' intent or the system's structure.

Furthermore, the rule drafters in 1938 could not have meant to adopt an absolute principle requiring that cases always be decided on the evidence. Evidence is costly to acquire and produce, so it is simply not practical to base every decision on a complete evidentiary record. As we demonstrate in Section D, a preliminary merits review at the certification stage strikes an appropriate balance between the need for evidence and the cost of obtaining it. In our proposal, the parties are allowed to conduct limited precertification discovery and to argue about the adequacy of one another's evidentiary presentations. Although precertification discovery must be strictly limited, even limited discovery has a good chance of revealing salient evidence. And the reason for not allowing more extensive discovery is perfectly consistent with the factors that justify limitations more generally-in this case, expansive discovery would be too costly at the certification stage.

Even if a ban on early merits review were consistent with the rule drafters' intent, the realities of contemporary litigation militate against such a ban. The original commitment to deciding cases on the evidence assumes that most cases will be resolved by formal adjudication. The fact is, however, that most class action suits settle, ${ }^{129}$ and set-

129. See, e.g., Amchem Prods., Inc. v. Windsor, 521 U.S. 591, 618 (1997) (observing that the use of the settlement-only class has become a "stock device"); Bryan G. Garth, Civil Litigation Through the Class Action, 62 IND. L.J. 497, 501-04 (1987) (noting that most class actions settle prior to trial, that certification is the crucial stage for settlement, and that a decision not to certify "reduces the bargaining power of the plaintiff and the will to continue the fight"); Thomas E. Willging et al., An Empirical Analysis of Rule 23 to Address the Rulemaking Changes, 71 N.Y.U. L. REV. 74, 142-44 (1996) (presenting evidence that suggests that many class action settlements occur shortly after or at the time of certification); see also Priest, supra note 4, at 522 (observing that "virtually every mass tort action that has been successfully certified has settled out of court rather than been litigated to judgment"). To be sure, the settlement rate is very high for litigation in general-by most estimates, approximately seventy percent of all cases filed in federal court end in pretrial settlement. See, e.g., Resnik, supra note 15, at 926 nn.10-11 (reporting on the empirical studies). Although hard to substantiate empirically, see HENSLER ET AL., supra note 34 , at $126 \mathrm{n} .52$ (discussing the absence of comprehensive data on class actions in both state and federal courts), there is reason to believe that certified class actions settle at a 
tlement encourages strategic behavior that can produce high social costs. These strategic costs are a principal source of concern, and as we shall see in the following Section, the main reason for requiring a preliminary merits review at the certification stage. ${ }^{130}$

\section{The Error-Cost Argument}

Some courts invoking the Eisen rule emphasize the provisional nature of the certification decision. ${ }^{131}$ The idea is that the judge can always correct an erroneous certification later when she has access to the fruits of discovery and greater experience with the litigation. Some courts go even further and note the importance of a generous approach to certification for securing the policy benefits of the class action, especially in those cases where the claims are too small to be brought individually. ${ }^{132}$

These points make most sense as components of an argument based on expected error costs. ${ }^{133}$ The goal of an error-cost analysis is

higher rate, see WILLGING ET AL., supra note 31, at 60, 179 tbl. 40 (noting that the settlement rates for cases brought as class actions within four federal districts were two to five times higher if a class was certified than if it was not); Garth, supra, at 501 (finding a 78\% settlement rate for certified class actions compared to a $15 \%$ settlement rate for noncertified cases in a sample of 119 class action cases from the Northern District of California).

130. Adapting principles to changing conditions is perfectly consistent with an argument from drafters' intent. The original rule drafters understood that litigation conditions would change over time, and they made the Federal Rules flexible enough to adjust. See Robert G. Bone, Mapping the Boundaries of a Dispute: Conceptions of Ideal Lawsuit Structure from the Field Code to the Federal Rules, 89 COLUM. L. REV. 1, 99-100 (1989) (citing the drafters' preference for flexibility and discretion over procedural formalism). Given the strong link between rules and underlying principles, it is reasonable to suppose that the drafters intended flexibility to operate at the level of principle as well.

131. According to Rule 23(c)(1), a certification order "may be altered or amended before the decision on the merits." FED. R. CIV. P. 23(c)(1). This factor is cited frequently. See Esplin v. Hirschi, 402 F.2d 94, 99 (10th Cir. 1968) ("But if there is to be an error made, let it be in favor and not against the maintenance of the class action, for it is always subject to modification should later developments during the course of the trial so require."); Barnes v. Am. Tobacco Co., 176 F.R.D. 479, 492-93 (E.D. Pa. 1997) ("Thus, even though this case may present a close question as to whether this action should be certified under Rule 23(b)(2), the Court will grant certification because the Court may amend the certification order before a decision on the merits ...."); 7B WRIGHT, MILLER \& KANE, supra note 3, § 1785, at 128-30 (observing that the power to decertify later has encouraged many courts to grant certification very liberally).

132. See, e.g., Gary Plastic Packaging Corp. v. Merrill Lynch, Pierce, Fenner \& Smith, Inc., 903 F.2d 176, 179 (2d Cir. 1990) (stating that Rule 23 factors should be construed liberally "[i]n light of the importance of the class action device in securities fraud suits"); In re Lease Oil Antitrust Litig., 186 F.R.D. 403, 419 (S.D. Tex. 1999) (noting that doubts should be resolved in favor of certification given the important role of private enforcement of the antitrust laws).

133. See, e.g., Council of \& for the Blind of Del. County Valley, Inc. v. Regan, 709 F.2d 1521, 1546 (D.C. Cir. 1983) (Robinson, C.J., concurring in part and dissenting in part): 
to minimize the expected cost of judicial error. In a perfect world, judges would make all certification decisions correctly. Certification would be granted whenever the case satisfied Rule 23's requirements and denied when it did not. There would be no need for the Eisen rule or any other limitation on what a judge could consider. Indeed, the judge would have to be free to examine all the relevant evidence to ensure an accurate result.

We do not live in a perfect world, however. Judges make mistakes. They grant certification when it should be denied, and they deny certification when it should be granted. Each of these mistakes generates its own costs. An erroneous grant creates unnecessary administrative and litigation costs and can pressure defendants to pay for unjustified settlements. An erroneous denial adds to plaintiffs' litigation costs and can make it harder for plaintiffs to recover.

The objective, from an error-cost perspective, is to choose the procedural rule (or rules) that minimizes the total cost of error. Suppose, for example, that the choice is between two certification rules, Rule A and Rule B, and suppose that judges make fewer erroneous grants and fewer erroneous denials when they use Rule A. In this situation, Rule A is obviously superior to Rule B since it improves judicial accuracy across the board.

Policy choices are seldom so easy, however. Usually there is no single rule that reduces both types of error-erroneous grants as well as erroneous denials. Normally, rules reduce one type of error but increase the other. Consider a familiar example outside the class action setting: the choice between a preponderance-of-the-evidence rule and a reasonable-doubt rule for the burden of persuasion at trial. Neither rule is an easy choice based on the error rate alone. Relative to the preponderance rule, the reasonable-doubt rule reduces the number of erroneous convictions-but it also increases the number of erroneous acquittals. Which rule one chooses depends on how one assesses the harm of erroneous convictions relative to the harm of erroneous acquittals.

In these hard cases, therefore, the choice must turn not just on the error rate, but also on the relative importance-or costs-of the two kinds of error. The reason we choose the reasonable-doubt rule

Better it is, in any sort of case, to utilize class certification liberally when suitdismissals would chance the loss of a meritorious claim forever. Should the soundness of the determination on class-action status be later drawn into question . . Rule 23 itself suggests a ready means for the handling the problem [through amendment or alteration of certification later]. 
in criminal cases, for example, is because we believe that the cost of an erroneous conviction-the potential deprivation of liberty-is much greater than the cost of an erroneous acquittal. As the aphorism goes, it is better to acquit ten guilty persons than to convict an innocent one. ${ }^{134}$

Returning to our class certification problem, the choice of rule, when no rule is a clear winner, must depend on how the cost of erroneous grants compares to the cost of erroneous denials. From this perspective, the crucial feature of the Eisen rule is that it reduces erroneous denials but increases erroneous grants. With this framework, we can see why courts emphasize the two factors they do: the provisional nature of certification and the social policies served by the class action. The first factor downplays the significance of erroneous grants-if initial certification is provisional, then an erroneous grant can be corrected later on-while the second factor plays up the importance of erroneous denials-if the class action serves important social policies, an erroneous denial is likely to be quite costly.

The argument in this simple form is superficially appealing, but it does not survive close analysis. As we shall see, initial certification is much more likely to be permanent than provisional. Moreover, erroneous denials are not nearly as costly or as likely as the argument assumes. Combining these factors with the potentially high cost of erroneous grants, it is clear that the error-cost analysis, far from supporting the Eisen rule, actually undermines it.

1. The Overall Structure of the Argument: Three Propositions. Let us systematize these points in a somewhat more rigorous way. ${ }^{135}$ The expected cost of an error is just the social $\cos t^{136}$ of the error discounted by the probability that the error will in fact materialize. As we saw, two different types of error must be considered: false grants

134. In most civil cases, on the other hand, we choose the preponderance rule because we believe that the costs of the two kinds of error are roughly equivalent.

135. Error-cost analysis is a branch of decision theory and has been developed extensively in that literature. See generally R. DUNCAN LUCE \& HOWARD RAIFFA, GAMES AND DECISIONS: INTRODUCTION AND CRITICAL SURVEY (1957) (providing a comprehensive analysis of game theory and related decisionmaking models). It also has been applied frequently to legal problems in a number of different areas. See, e.g., C. Frederick Beckner III \& Steven C. Salop, Decision Theory and Antitrust Rules, 67 ANTITRUST L.J. 41, 61-75 (1999) (applying a basic decisionmaking theoretic framework to antitrust litigation).

136. By "social cost," we mean no more than the total harm caused by the error. This harm can be moral as well as economic in character. See infra note 233. 
of certification and false denials. ${ }^{137}$ In the certification context, a false grant is a grant of certification in a case that in fact does not qualify for certification under Rule 23, either because it is substantively frivolous or because while meritorious it does not in fact meet the Rule's requirements. A false denial is a denial of certification in a case that is substantively meritorious and in fact qualifies for certification under Rule $23 .{ }^{138}$

To illustrate how this analysis applies to the Eisen rule, consider a hypothetical choice between two rules: Rule E and Rule N. Rule E ("E" for Eisen) is the strict form of the Eisen rule: it forbids any inquiry into the evidence and the plaintiffs' likelihood of success on the merits at the certification stage. Suppose as well that Rule E includes, as it does in many cases, a presumption favoring initial certification. Rule N ("N" for Not-Eisen) is our modest proposal. It requires an explicit inquiry into the evidence and a determination of whether the plaintiff has a significant likelihood of success on a merits-related issue whenever the issue is relevant to Rule 23's certification analysis. ${ }^{139}$

In this hypothetical, the error-cost argument for choosing Rule E over Rule $\mathrm{N}$ can be systematized in the following three propositions:

(1) Rule E reduces the number of false denials of certification but increases the number of false grants compared to Rule N.

137. In the decision-theoretic literature, these two types of error are known as "false positives" (or Type I error) and "false negatives" (or Type II error). See, e.g., Lynn A. Stout, Type I Error, Type II Error, and the Private Securities Litigation Reform Act, 38 ARIZ. L. REV. 711, 711 (1996) (defining and using these terms). See generally Alvin W. DRAKE, Fundamentals of APPLIED PROBABILITY THEORY 240-41 (1967) (discussing Type I and Type II errors).

138. More precisely, an error-cost analysis considers four variables: (1) the probability of a false grant (i.e., an erroneous grant of certification); (2) the cost of a false grant; (3) the probability of a false denial (i.e., an erroneous denial of certification); and (4) the cost of a false denial. The expected cost of a false grant or a false denial is simply its probability multiplied by its cost. And the goal of the error-cost analysis is to minimize the sum of the expected costs of the two types of error: that is, to minimize the expected cost of false grants plus the expected cost of false denials.

139. See supra notes $101-08$ and accompanying text. Although we recommend a likelihood of success standard, Rule $\mathrm{N}$ could incorporate a different standard for determining the minimum merits threshold, such as nonfrivolousness or the summary judgment test. See supra note 105. Whatever the standard, however, Rule $\mathrm{N}$ requires an explicit determination of whether plaintiffs' evidence on the issue meets the standard. For example, suppose the defendant argues that Rule 23's commonality or predominance requirements are not satisfied because the allegedly common question is too weak or frivolous. Under any version of Rule $\mathrm{N}$, the trial judge must examine all the relevant evidence available at the certification stage and make an explicit determination as to whether the plaintiff meets the threshold standard with respect to the common question. If the plaintiff does not meet the standard, the judge must ignore the common question when determining commonality and predominance. 
(2) A false denial is likely to be more costly than a false grant:

(2a) False grants can be corrected, whereas false denials are more likely to be permanent.

(2b) The cost of a false denial is the potentially high cost of frustrating the important social policies of the class action, whereas the cost of a false grant is, by virtue of (2a), mainly just the cost of managing a class action for the period between initial certification and later reconsideration, dismissal, or summary judgment.

(3) Therefore, Rule E is superior to Rule N. In short, Rule E minimizes expected error costs by reducing the number of false certification denials (see [1] above) where false denials are the more costly kind of error (see [2] above).

By structuring the argument in this way, we can see exactly where its weaknesses lie. The first thing to note is that Proposition 1 is clearly valid. The Eisen rule's cursory analysis and liberal attitude toward certification produces a high rate of certification. Thus, Rule E obviously reduces the risk of false certification denials and increases the risk of false grants. ${ }^{140}$

However, both Propositions 2 and 3 are seriously flawed. In brief, there are two major problems. First, and most important, Proposition 2 ignores the fact that most class actions settle, often soon after certification. ${ }^{141}$ By eliminating the reconsideration option, early settlement undermines the validity of Proposition 2a. Also, settlement changes the cost of false certification grants with consequences for the validity of Proposition $2 b$.

The second serious problem is in Proposition 3. The conclusion that Rule E is superior depends not on whether Rule E creates fewer false certification denials than Rule N, as Proposition 3 assumes, but on how many fewer false denials it creates and how this compares to the number of false grants it adds. In particular, whether Rule E is

140. To be sure, Rule E also makes it easier for defendants to introduce frivolous or weak affirmative defenses to scuttle a finding of commonality, predominance, or superiority. See Broussard v. Meineke Disc. Muffler Shops, Inc., 155 F.3d 331, 342 (4th Cir. 1998) (noting that class certification may be inappropriate where affirmative defenses turn on facts peculiar to each plaintiff's case). Yet given the limited range of defenses and the presumption in favor of certification, it seems reasonable to assume that plaintiffs will succeed in obtaining certification erroneously far more often than defendants will succeed in opposing it.

141. See supra note 129 and accompanying text. 
better than Rule $\mathrm{N}$ depends on whether the benefit of Rule $\mathrm{E}$ is worth the price-or more precisely on how the reduction in false certification denials (the benefit) compares to the increase in false certification grants (the price). Even if the cost of a false denial exceeds the cost of a false grant, the price for Rule E still can be too high. ${ }^{142}$

The following discussion examines these points more closely.

\section{The Flaws in Proposition 2.}

a. Class certification and settlement. Proposition 2b assumes that the cost of managing the class action between initial certification and later reconsideration is relatively low. This assumption underestimates the complexity of class action litigation. ${ }^{143}$ Management of a large class action requires coordination of multiple attorneys, close supervision of discovery, and extensive involvement by the judge in many aspects of the litigation process. The higher the judicial management and litigation costs during the period between certification and reconsideration, the greater the expected costs that a false grant of certification creates.

Much more important, however, is the fact that Proposition 2 ignores the impact of settlement. This is a very serious omission because the vast majority of certified class actions settle, most soon after certification. ${ }^{144}$ A 1995 study of terminated class actions in four federal districts, conducted by the Federal Judicial Center, found that "the percentage of certified class actions terminated by a class settlement ranged from $62 \%$ to $100 \%$ " depending on the federal district court. ${ }^{145}$

142. To see this point mathematically, let $r_{E}$ be the probability of a false grant of certification when Rule $\mathrm{E}$ is in effect, and let $r_{N}$ be the same probability when Rule $\mathrm{N}$ is in effect. Let $s_{E}$ be the probability of a false denial when Rule $\mathrm{E}$ is in effect, and let $s_{N}$ be the same probability when Rule $\mathrm{N}$ is in effect. Let $c_{G}$ be the cost of a false grant and $c_{D}$ the cost of a false denial. Then Rule $\mathrm{E}$ is superior to Rule $\mathrm{N}$ only if: $r_{E} c_{G}+s_{E} c_{D}<r_{N} c_{G}+s_{N} c_{D}$. Rewriting this inequality, we get:

$$
\left[r_{E}-r_{N}\right] /\left[s_{N}-s_{E}\right]<c_{D} / c_{G}
$$

That is, the ratio of the difference in the probability of false grants to the difference in the probability of false denials must be less than the ratio of false denial cost to false grant cost. Therefore, if $r_{E}-r_{N}$ is much greater than $s_{N}-s_{E}$, then (1) might not hold-even if $c_{D}$ is greater than $c_{G}$. For an example and additional analysis, see infra note 230.

143. See, e.g., HENSLER ET AL., supra note 34, at 475 (remarking on the high transaction costs associated with class action litigation).

144. See supra note 129 and accompanying text.

145. The actual distribution of figures is $62 \%$ in the Eastern District of Pennsylvania, $66 \%$ in the Northern District of Illinois, $88 \%$ in the Northern District of California, and $100 \%$ in the Southern District of Florida. WILlGING ET AL., supra note 31, at 179 tbl. 40; see also Garth, su- 
Only about $9 \%$ of all the certified class actions in the four districts actually went to trial. ${ }^{146}$

Other empirical studies, although few in number, show similar results, ${ }^{147}$ and together they confirm what most class action lawyers know to be true: almost all class actions settle, and the class obtains substantial settlement leverage from a favorable certification decision. ${ }^{148}$ As we discuss below, this settlement leverage creates serious problems when deployed in frivolous or weak class action suits, and the Eisen rule exacerbates the problems by granting certification without a serious inquiry into the merits. Put simply, because plaintiffs file frivolous and weak cases to obtain a settlement, the greater prospect of settlement with successful certification should encourage plaintiffs to file more frivolous and weak class action suits.

Let us take a closer look at this relationship between certification and frivolous litigation. At the outset, it is important to be clear that there are two ways for a class action to be frivolous or weak. The most obvious way is for the individual legal claims of class members to be substantively defective. "Frivolous" in this sense means, roughly speaking, a suit with no (or very little) objective factual basis for liability on the legal theories actually alleged. ${ }^{149}$ Alternatively, the substantive claims of class members might be substantial, even strong, on the merits while the class itself, at least as plaintiffs seek to define it, fails to meet Rule 23's requirements. "Frivolous" in this second sense

pra note 129, at 501 (finding a 78\% settlement rate for certified class actions in a sample of 119 class action cases from the Northern District of California).

146. The distribution is $14 \%$ in the Eastern District of Pennsylvania, $6 \%$ in the Northern District of Illinois, $13 \%$ in the Northern District of California, and $0 \%$ in the Southern District of Florida. WILLGING ET AL., supra note 31, at 140 fig. 56. The study authors emphasize, however, that "inferences about the universe of trials in class actions nation-wide cannot be made from these aggregated results." Id. at 66.

147. See, e.g., Garth, supra note 129, at 501-04 (finding that thirty-six of forty-six certified class actions settled before trial).

148. The Federal Judicial Center study almost certainly understates the actual frequency of class action settlement because of the limitations of the database and reporting protocol. The database excluded mass tort class actions, one of the most settlement-prone areas of class action litigation, and the settlement rate statistics excluded class actions filed only for settlement purposes.

149. A frivolous suit is not necessarily the same thing as a suit with too little at stake to justify the costs of litigation (in other words, a suit with negative expected value). See Robert G. Bone, Modeling Frivolous Suits, 145 U. PA. L. REV. 519, 529-33 (1997) (discussing the problems with defining frivolousness and proposing a two-part definition). We also include in the definition suits with "very little" factual basis for liability to allow for the possibility that a court system might choose to exclude lawsuits that are not strictly frivolous but that are too weak on the merits to justify the expenditure of litigation resources. 
refers to a class action in which class allegations or the class definition are not supported by the evidence.

As an example of the second situation, a judge might certify a (b)(3) class action in a relatively strong securities fraud case by relying on a fraud-on-the-market theory to establish predominance, when a closer examination of the evidence would reveal that the conditions for that theory are not satisfied. ${ }^{150}$ Or the evidence might support certification of some classes but not the broad class that the plaintiffs seek-as when the judge certifies a company-wide class on flimsy evidence of company-wide discrimination when he should have certified narrower classes limited to individual departments. In these cases, the certification decision or the broad class definition is inconsistent with Rule 23's limits.

The severity of the frivolous class action problem-especially the problem of substantively frivolous suits-has been a matter of serious concern and heated debate since the early 1970 s. ${ }^{151}$ The focus intensified in the 1990s with a rise in the number of mass tort class actions and renewed Advisory Committee interest in revising Rule 23. ${ }^{152}$ Moreover, in 1995, Congress adopted the Private Securities Litigation Reform $\mathrm{Act}^{153}$ in response to mounting evidence of frivolous securities fraud class actions. ${ }^{154}$ And in recent years, courts have begun to take explicit note of the connection between class certification, settlement pressure, and frivolous or weak class action filings. ${ }^{155}$

Notwithstanding this keen interest, there is little hard empirical evidence available to quantify the severity of the problem. ${ }^{156}$ The main reason has to do with the high rate of settlement-settlement con-

150. See supra notes $82-87$ and accompanying text.

151. See HENSLER ET AL., supra note 34, at 15-37, 93-99 (discussing the controversy over rampant class action suits brought in the 1970s and the collusion fears of class actions).

152. See id. at 22-37, 62-68 (tracing the steps of the Advisory Committee in the 1990s in its attempted revision of Rule 23 following a report from a special judicial committee on asbestos litigation).

153. Pub. L. No. 104-67, 109 Stat. 737 (codified in various provisions of 15 U.S.C. § 77 (Supp. III 1997)).

154. For the history of the Private Securities Litigation Reform Act, see generally Joel Seligman, The Private Securities Reform Act of 1995, 38 ARIZ. L. REV. 717 (1996).

155. See, e.g., Castano v. Am. Tobacco Co., 84 F.3d 734, 746 (5th Cir. 1996) (noting that "class certification creates an insurmountable pressure on defendants to settle, whereas individual trials would not"); In re Rhone-Poulenc Rorer, Inc., 51 F.3d 1293, 1299-1300 (7th Cir. 1995) (discussing the implications of the plaintiffs' claims lacking legal merit).

156. See HENSLER ET AL., supra note 34, at 93-94 (noting the lack of hard data and the difficulty of obtaining objective reports from lawyers). 
ceals evidence of frivolousness. ${ }^{157}$ Even so, the few studies that are available tend to support a correlation between class action settlement and frivolous litigation, at least in some settings. For example, a 1991 study of a sample of securities fraud class actions showed that the cases tended to settle for standard amounts that bore no relation to the underlying merits. ${ }^{158}$ Moreover, a somewhat more recent study of securities class actions, conducted on a much larger sample and analyzed using more sophisticated statistical techniques, found strong evidence of frivolous suits, leading the author to conclude that "most securities fraud class actions are, in fact, frivolous." 159 In addition, there is some empirical evidence suggesting that stockholder class and derivative litigation might have similar problems. ${ }^{160}$

Although these studies are limited, their results are consistent with theoretical work on settlement and frivolous suits. The settlement literature shows why class actions attract frivolous litigation and why the Eisen rule is a substantial contributing cause. Three features of class action litigation play a key role: first, the class action magnifies the stakes through aggregation; second, it increases the defen-

157. When a case settles, there is no formal review of the merits. Moreover, because of selection effects, one cannot extrapolate from the results in those few cases that actually are tried. And researchers have very little access to information about settlement amounts, because settlements normally are kept confidential.

158. See Janet Cooper Alexander, Do the Merits Matter? A Study of Settlements in Securities Class Actions, 43 STAN. L. REV. 497, 570-77 (1991) (revealing that the "securities laws have been transformed . . . into a system of insurance against large stock market losses"). This particular study is quite controversial. See Elliott J. Weiss \& John S. Beckerman, Let the Money Do the Monitoring: How Institutional Investors Can Reduce Agency Costs in Securities Class Actions, 104 YALE L.J. 2053, 2079-88 (1995) (criticizing Alexander's study, but conceding that there may well be a frivolous suit problem in securities class actions).

159. James Bohn \& Stephen Choi, Fraud in the New-Issues Market: Empirical Evidence on Securities Class Actions, 144 U. PA. L. REV. 903, 979 (1996). For a summary of some other statistical studies of securities class actions, see $i d$. at $910 \mathrm{n} .32$ (noting that the studies identified and discussed provide "conflicting evidence as to the importance of merit in securities class action settlements").

160. See Roberta Romano, The Shareholder Suit: Litigation Without Foundation?, 7 J.L. ECON. \& ORG. 55, 66-75 (1991) (presenting data showing that few shareholder lawsuits go to trial, that those that do involve trivial violations, and that shareholder litigation has little impact on corporate behavior). For an earlier study that purported to show a high rate of frivolous settlements in class and derivative litigation brought against corporate officers and directors, see Thomas M. Jones, An Empirical Examination of the Resolution of Shareholder Derivative and Class Action Lawsuits, 60 B.U. L. REV. 542, 548-59 (1980) (charting the results of settlements of shareholder derivative and class action suits). See generally John C. Coffee, Jr., The Unfaithful Champion: The Plaintiff as Monitor in Shareholder Litigation, 48 LAW \& CONTEMP. PROBS. 5, 9 (Summer 1985) (reviewing the strengths and limitations of the Jones study and other similar results). 
dant's risk-bearing, litigation, and reputation costs; and third, it enlists the trial judge in the settlement process. To see more precisely how these factors attract frivolous suits, we must examine-if only briefly - the standard theoretical models of frivolous litigation: the trial-error model, the asymmetric-cost model, and the asymmetricinformation model. ${ }^{16}$

The trial-error model explains frivolous filings and settlements in the most straightforward way. ${ }^{162}$ When trial error is substantial enough, even a frivolous suit is worth taking to trial and thus worth settling. ${ }^{163}$ In this model, the most salient feature of class litigation is its effect on the stakes. If the plaintiff brings only an individual suit, the stakes are usually too small relative to litigation costs to justify taking a frivolous suit to trial under most plausible assumptions about trial error. ${ }^{164}$ The class action, however, combines a large number of individual suits and magnifies the expected recovery to such an extent that going to trial can be a rational option. Under these circumstances, an entrepreneurial class attorney will have a strong incentive to file a frivolous suit if he expects a substantial fee from a large class recovery. ${ }^{165}$ And when the attorney can make a credible threat to take

161. For a summary description of the various models, see Bone, supra note 149, at 534-66; see also John C. Coffee, Jr., Understanding the Plaintiff's Attorney: The Implications of Economic Theory for Private Enforcement of Law Through Class and Derivative Actions, 86 COLUM. L. REV. 669, 701-20 (1986) (discussing various explanations for frivolous strike suits, including asymmetric or "differential" cost models).

162. The central puzzle of frivolous litigation is to explain why a defendant ever is willing to settle a frivolous suit. If the plaintiff is almost certain to lose at trial, the plaintiff should drop the suit in response to the defendant's refusal to settle. Hence the puzzle: why doesn't the defendant simply refuse to settle and force the plaintiff to withdraw?

163. For an analysis of frivolous suits that assumes trial error makes individual litigation rational, see Lucian Arye Bebchuk \& Howard F. Chang, An Analysis of Fee Shifting Based on the Margin of Victory: On Frivolous Suits, Meritorious Suits, and the Role of Rule 11, 25 J. LEG. STUD. 371, 373-74 (1996).

164. See Bone, supra note 149, at 534-37 (noting that, in frivolous suits, the probability of trial error is not likely to be substantial).

165. By an entrepreneurial attorney, we mean an attorney who brings a class action for his own personal gain. Class attorneys often control class actions with little oversight from their clients and are motivated in many situations by self-interest. See John C. Coffee, Jr., The Regulation of Entrepreneurial Litigation: Balancing Fairness and Efficiency in the Large Class Action, 54 U. CHI. L. REV. 877, 896-917 (1987) (discussing the conflicting interests of plaintiffs' attorneys and their clients with regard to class certification, opt-out provisions, and individual actions). To illustrate, suppose that, due to trial error, a plaintiff with a frivolous case can expect to win at trial ten percent of the time. Suppose that the plaintiff expects a trial award of $\$ 100,000$ if he wins but also expects to spend $\$ 30,000$ litigating the case all the way through trial. Under these circumstances, it would not be worthwhile for the plaintiff to sue, because the expected trial value of his case is negative: $0.1 \times 100,000-30,000=-\$ 20,000$. Now suppose that there are 
the class action to trial, the defendant must consider settlement very seriously. Indeed, the other two features of class litigation-high costs and trial judge involvement in settlement-only add to the pressure and make it harder for the defendant to resist settlement, as we discuss more fully below. ${ }^{166}$

The other two models of frivolous litigation-the asymmetriccost model and the asymmetric-information model-apply even when the error risk and the stakes are not large enough to support a credible trial threat. ${ }^{167}$ The asymmetric-cost model predicts that the defendant will settle a frivolous suit when the plaintiff can leverage a cost advantage by threatening to impose greater costs on the defendant than the defendant can impose on the plaintiff. ${ }^{168}$ The asymmetricinformation models instead turn on the plaintiff's ability to leverage an informational asymmetry. In the simplest version, the defendant is uncertain whether the plaintiff's suit is frivolous, so a frivolous plaintiff can masquerade as meritorious and sometimes fool the defendant into offering a substantial settlement. ${ }^{169}$

10,000 identical cases and suppose that an entrepreneurial attorney considers whether to bring a class action aggregating all 10,000 cases. Suppose the attorney expects to receive one-quarter of the recovery if he obtains certification and wins the class action. The attorney then has an expected fee award of twenty-five million dollars- $0.1 \times 0.25 \times 10,000 \times 100,000=\$ 25$ million. Under these circumstances, the attorney could make a credible threat to take the case all the way through trial provided the expected litigation costs are less than $\$ 25$ million. Even after adjusting for risk aversion, his incentives to litigate are strong.

166. Furthermore, a corporation can experience serious and possibly crippling — even bankrupting — cash flow problems dealing with a large class action judgment. Settlement is often an attractive alternative under these circumstances because the parties can work out a payment schedule consistent with the defendant's cash flow constraints. Therefore, if because of trial error class certification makes it attractive for the class attorney to take the case to trial, the defendant will have to worry about the cash flow risk.

167. These models deal mainly with the simple case of one plaintiff and one defendant, see Bone, supra note 149, at 534-66 (describing the models), but the basic insights extend to class litigation as well.

168. The primary articles developing the asymmetric-cost models all assume that the parties have complete information about the merits; that is, both the plaintiff and the defendant know that the suit is frivolous. It is important to note, however, that these models do not depend just on asymmetric costs; they also depend on the relative timing of cost expenditures. See Lucian Arye Bebchuk, A New Theory Concerning the Credibility and Success of Threats to Sue, $25 \mathrm{~J}$. LEG. STUD. 1, 5-10 (1996) (recognizing that the litigation costs in negative-expected-value suits incur gradually rather than all at once); David Rosenberg \& Steven Shavell, A Model in Which Suits Are Brought for Their Nuisance Value, 5 INT'L. REV. L. \& ECON. 3, 3-10 (1985) (assuming the defendant must incur a cost to respond to a complaint before the plaintiff need spend anything more).

169. The defendant is willing to offer the settlement because it is better than incurring the costs of litigation if the case turns out to have merit. See Lucian Arye Bebchuk, Suing Solely to Extract a Settlement Offer, 17 J. LEG. STUD. 437, 441-48 (1988) (showing how informational 
The class action's effect on costs and the judge's involvement in class settlement combine to enhance the incentives to file frivolous suits in these two models. Costs that follow on the heels of class certification are often asymmetrically distributed in the way that the asymmetric-cost model requires. ${ }^{170}$ Moreover, judicial pressure to settle works in favor of frivolous settlements, especially when the judge ignores the merits. Since the defendant settles in asymmetricinformation models to avoid the costs of litigating, the higher those costs and the more aggressive the judge's involvement, the greater the pressure on the defendant to settle and the more attractive it is for the plaintiffs to file frivolous suits. ${ }^{171}$

Let us examine these factors more closely. As to costs, there are three types affected by class certification: risk-bearing costs, litigation costs, and reputation costs. High risk-bearing costs follow from the all-or-nothing nature of the class action gamble: either the defendant is liable to everyone in the class (a potentially huge liability) or to no

asymmetries may allow plaintiffs to extract settlement offers); Avery Katz, The Effect of Frivolous Lawsuits on the Settlement of Litigation, 10 INT'L REV. L. \& ECON. 3, 25 (1990) (analyzing the "equilibrium suit and settlement strategies" for frivolous strike suits). In other versions, it is the plaintiff who is uninformed, often because of a failure to investigate before filing. A plaintiff's ignorance of the frivolous nature of her suit allows her to make a credible threat to litigate, which induces the defendant to settle. See Bone, supra note 149, at 600 (describing a pure pooling equilibrium, where defendants are willing to settle all the time rather than go to trial sometimes against legitimate plaintiffs, and both legitimate and frivolous plaintiffs, expecting a satisfactory settlement, do not bother to investigate before filing and always accept a defendant's offer). These models are particularly complex and do not always predict settlement of frivolous suits. However, they do predict that frivolous suits will be filed in substantial numbers and will have adverse social effects. See id. at 550-64 (discussing the "informed-defendant model").

170. Sometimes it is in the interest of a defendant to adopt a fighting strategy to develop a reputation for aggressively battling frivolous suits. See Bone, supra note 149, at 539-41 (discussing the possibility of a fighting strategy). Such a reputation can reap benefits in the long run by discouraging frivolous plaintiffs from filing. For several reasons, however, a fighting strategy is likely to be much less effective in the class action setting. First, the strategy works only if both the plaintiff and the defendant know the class action is frivolous, for only then can the defendant target its fighting strategy at frivolous suits and get public credit for doing so. Second, the class action aggregates lots of the suits that the defendant would otherwise try to deter. With fewer suits left to reap the benefits of a fighting strategy, the defendant's incentives to use the strategy are much weaker. Third, the high potential stakes in a class action make a fighting strategy very costly if the defendant loses.

171. The analysis is more complex than this and depends to some extent on the structural features of the various equilibria and the exogenous conditions that support those equilibria. This Article is not the forum to present a thorough analysis. It is enough to note that the factors are likely to produce a substantial number of frivolous filings and settlements under a wide range of conditions. 
one. ${ }^{172}$ The risk is very different when certification is denied. Assuming that all class members bring individual suits, the defendant has an opportunity to litigate each suit separately, and the chances are very good that the defendant will win some and lose some. ${ }^{173}$ Moreover, when individual suits are litigated sequentially, plaintiffs and defendants gain information from the earlier cases that helps them assess the merits of later cases, deal better with frivolous filings, and work out reasonable settlements for the meritorious suits. ${ }^{174}$

It is true that corporate defendants tend to be risk-neutral, but they are likely to become more risk-averse as the potential class-wide liability represents a larger fraction of corporate assets. ${ }^{175}$ Further-

172. It is not just the highly publicized mass tort class action that risks potentially crippling liability. For example, in the retailer class action antitrust suit against the VISA and Mastercard card associations, the plaintiff class seeks damages that could reach $\$ 63$ billion, which would total $\$ 189$ billion after trebling. See In re VISA Check/MasterMoney Antitrust Litig., No. 00-7699, 2001 U.S. App. LEXIS 22480, at *57, *60,*70-*71 (2d Cir. Oct. 17, 2001) (Jacobs, J., dissenting) (stressing the enormous potential liability and the coercive effect on settlement).

173. That is, the defendant will win some and lose some assuming no offensive collateral estoppel on the common issues. See Parklane Hosiery Co. v. Shore, 439 U.S. 322, 331 (1979) (introducing the possibility of offensive nonmutual collateral estoppel in federal court); Hardy v. Johns-Manville Sales Corp., 681 F.2d 334, 345-48 (5th Cir. 1982) (refusing to allow offensive collateral estoppel). To see why this fact alone reduces the risk for the defendant, consider the following mathematical analysis. Suppose that the class has 1000 members and that each class member has a 0.1 probability of winning on liability (since the suit is frivolous, the 0.1 is just the probability of judicial error). If a class is certified, the defendant faces two possible outcomes: either defendant is held liable to 1000 class members (with a probability of 0.1 ) or to no class members (with a probability of 0.9 ). The mean of this two-point distribution is 900 defendant wins, and the variance is: $0.9 \times(1000-900)^{2}+0.1 \times(900-0)^{2}=90,000$. On the other hand, if certification is denied, there are 1001 possible outcomes. The defendant might win all 1000 individual suits, or he might win 1 suit and lose 999, or he might win 2 suits and lose 998-and so on. One can calculate the probability distribution over all these possible outcomes. Assuming that all the outcomes are mutually independent, the distribution can be modeled as a binomial distribution. The mean of the distribution is the same as for the certified class action-900 winsbut the variance is much smaller: $1000 \times 0.1 \times 0.9=90$. The reason for the reduced variance is that the binomial distribution clusters tightly around the mean of 900 wins, which is to say that the probability of an outcome close to the mean is very high. One can see this most clearly for the endpoints of the distribution: while the probability of 1000 losses and 0 wins is 0.1 for a certified class action, it is a miniscule $(0.1)^{1000}$ for individual litigation. In general, if the population of lawsuits is large enough, the binomial distribution closely approximates a normal distribution. In our case, this means that there is roughly a $95 \%$ probability that the defendant will lose somewhere between 80 and 120 individual suits-a lot less risky situation than facing a $10 \%$ chance of losing all 1000 suits.

174. See, e.g., Francis E. McGovern, Toward a Functional Approach for Managing Complex Litigation, 53 U. CHI. L. REV. 440, 442 (1986) (discussing the advantages of mature mass tort litigation).

175. See, e.g., In re Rhone-Poulenc Rorer, Inc., 51 F.3d 1293, 1298-99 (7th Cir. 1995) (describing the effect of certification on a company's willingness to take risk); Alexander, supra 
more, class attorneys often sue corporate officers and directors to exploit their greater risk aversion and pressure them to authorize a settlement on behalf of the corporation. ${ }^{176}$ Indeed, in a world of agency costs, corporate officers, fearful of losing salary, stock value, and even jobs-or simply worried about having to account to shareholders for a huge liability loss-may experience considerable pressure to authorize a settlement that is not optimal for the corporation. It is true that when defendants know the class action is frivolous, they will presumably assign a low probability to the case succeeding at trial. ${ }^{177}$ However, even a small probability of success can produce a substantial increase in risk, especially when the number of suits in the class is very large. $^{178}$

For the asymmetric-cost model, it is important to consider the effect of certification on the risk-bearing costs of the plaintiff as well, since that model depends on costs being not only high but also different across the party line. ${ }^{179}$ Although the matter is not entirely clear, there is reason to believe that certification has a weaker impact on plaintiffs' risk-bearing costs. For example, certification has little effect on each class member's individual litigation gamble, since she gets at most one chance to litigate her case with or without certification. ${ }^{180}$ As for the class attorney, certification does create an all-or-nothing gamble, but the class attorney has various ways to manage the risk. ${ }^{181} \mathrm{Un}$ -

note 158 , at 532 (arguing that "the stakes in many securities class actions are high enough to threaten the continued existence of the company," which can generate risk-averse behavior).

176. See, e.g., Alexander, supra note 158, at 529-32 (discussing the strategy of securities fraud plaintiffs to sue risk-averse outside directors for punitive damages to apply pressure on the corporation to settle); Romano, supra note 160, at 57 (noting the strong settlement incentives for defendants who are corporate officers and directors).

177. This is significant for the asymmetric-cost models but not as significant for the asymmetric-information models. In the asymmetric-information models, it is the defendant's fear of having to try a meritorious suit that applies pressure to settle frivolous suits. Therefore, the additional risk-bearing costs in a meritorious suit will increase the plaintiff's settlement leverage in a frivolous suit.

178. See supra note 173 (analyzing an example with a ten percent probability of success).

179. This is not essential for asymmetric-information models, since they depend on informational rather than cost asymmetry. It is enough in those models that the defendant's costs are high, because avoiding those costs is what drives the defendant's eagerness to settle.

180. Class litigation requires each class member to give up a considerable amount of individual control, however, and this fact, combined with class attorney agency problems, can increase the risk for class members. Although this increase is difficult to estimate, it is unlikely to be as substantial as the increase for the defendant, especially if the class attorney assumes some of the risk through a contingency fee arrangement.

181. For example, the attorney has only his fees and costs at stake, which represent only a fraction of the total class recovery, while the defendant faces the prospect of paying for the en- 
like defendants, class attorneys can be selective about the class actions they bring, and they have an incentive to select those class actions that maximize the risk differential and thus the settlement leverage. Most important for our purposes, the attorney's gamble is not terribly risky when the suit is frivolous or very weak and the attorney does not intend to take it to trial anyway. ${ }^{182}$

In addition to increasing the defendant's risk-bearing costs, certification also increases defendant's litigation costs by expanding the scope of a case and opening up more opportunities for strategic litigation. ${ }^{183}$ For example, in an employment discrimination suit, certification of a company-wide class puts company-wide policies or practices at issue, expanding the opportunities for class counsel to engage in extensive and intrusive discovery. By promulgating a simple document request, the class attorney can force defendants to engage in a costly search of company records. ${ }^{184}$ Moreover, responding to such a request can sometimes put defendants in the awkward position of having to reveal marginally relevant but highly embarrassing facts that a settlement would conceal. To be sure, defendants also can make litigation costly for plaintiffs, but plaintiffs usually have less information to provide, especially if they are individuals, and are therefore much less vulnerable to cost-escalating strategies.

Reputation costs also are affected by certification. Turning a case into a class action elevates its public profile and can attract adverse publicity unrelated to the merits. Indeed, class representatives and the class attorney have incentives to exploit the publicity value of a

tire amount. Moreover, by maintaining a portfolio of cases, the class attorney can manage the risks through diversification. See Coffee, supra note 161, at 704-12 (discussing diversification and other factors that affect the risk preferences of a class attorney).

182. One more point deserves mention. If plaintiff's risk-bearing costs are a lot greater than the defendant's when suits are litigated individually, it is possible that class certification, rather than creating a cost asymmetry, will simply eliminate an existing asymmetry. However, this point does not hold for frivolous or very weak suits, which are the object of our concern, since there is little risk for plaintiffs who do not intend to try their cases. Even for meritorious suits, the prevalence of contingency fee arrangements should reduce the risk for plaintiffs litigating individually. The contingency fee shifts a good deal of that risk to the plaintiff's attorney, who can diversify by maintaining a portfolio of cases.

183. See John C. Coffee, Jr., Rethinking the Class Action: A Policy Primer on Reform, 62 IND. L.J. 625, 637-39 (1987) (discussing the various ways in which discovery can contribute to a cost asymmetry that advantages the class over the defendant).

184. Similarly, depositions often are more costly to defend than to take, especially when the deponent requires careful preparation. When both sides hire experts, there are more opportunities to multiply litigation costs. But the costs rise for both sides, leaving the other sources of asymmetry to dominate. 
class action to magnify the defendant's reputation costs and force a settlement. ${ }^{185}$ These adverse reputation effects add to defendant's costs of litigating and make settlement more attractive in frivolous suits.

The last factor-judicial settlement pressure-results from the fact that trial judges have a personal and professional stake in settling large class actions. ${ }^{186}$ The judge not only avoids a difficult and burdensome trial, but also enhances her reputation by successfully settling a major class action. Because of this, judges frequently encourage (some would even say force) settlement and occasionally appoint special masters to facilitate the bargaining process. ${ }^{187}$ Indeed, it sometimes seems as if the high probability of class settlement is the cause of a liberal judicial attitude toward certification: certification followed by settlement removes many cases from the court docket without the need for trial and with minimal risk of reversal on appeal. Faced with a trial judge bent on settlement, the defendant would run a serious risk if it rejected settlement overtures and held out for trial.

In sum, the theoretical analysis supports the general findings of most of the rather limited class action empirical studies: almost all class actions settle; the certification decision gives plaintiffs critical settlement leverage, and the leverage increases the prospects for frivolous class action suits. The Eisen rule magnifies the adverse ef-

185. See, e.g., Abdallah v. Coca-Cola Co., 186 F.R.D. 672, 674-75 (N.D. Ga. 1999) (describing the class attorneys' media contacts and use of a website to circulate information about a pending employment discrimination class action).

186. See, e.g., Peter Schuck, Agent Orange On Trial 178-79 (1986) (describing how Judge Weinstein pressured settlement in the Agent Orange class action despite reservations about liability); Resnik, supra note 15, at 948-49 (discussing the strong judicial preference for settlement and judicial involvement in settlement bargaining). One practicing lawyer describes the threats available to a judge in the following, perhaps overly dramatic, terms:

The judicial arsenal contains a wide range of weapons to induce settlement. A judge can refuse to rule on dispositive motions, thus turning up the heat on the defendant because of the sheer volume of pending cases. A judge can order that discovery be permitted into essentially all aspects of corporate life, and can include all suppliers, distributors, researchers, and other people in the world who have any relationship with the corporate defendant. A judge can order that depositions be taken at a rate that resembles the Bataan Death March. The judge may perceive, and perceive accurately, that a corporate defendant will have no choice but to capitulate.

Mark Herrmann, From Saccharin to Breast Implants: Mass Torts, Then and Now, LiTiGATION, at 50, 54 (Fall 1999).

187. See HENSLER ET AL., supra note 34, at 92 (discussing the role and potential abuses of special masters). Also, partly because of the strong judicial interest in settlement, trial judges do a relatively poor job of reviewing class action settlements under Rule 23(e). See id. at 98 (noting that "the failure of judges to vigorously ... monitor settlements and lawyers' fees was a theme in a number of interviews" with attorneys). 
fects by making it easier for plaintiffs to obtain certification in substantively frivolous cases and in cases otherwise meritorious that should not be certified.

b. Settlement and reconsideration of certification decisions. Proposition $2 \mathrm{a}$-false grants can be corrected whereas false denials are permanent-is premised on the assumption that a trial judge will revise a favorable certification decision later in the suit if a more thorough grasp of the evidence and greater experience with the case show that the initial decision was erroneous. Yet trial judges rarely reverse certification after granting it. ${ }^{188}$ This is not surprising given the strong judicial preference for settlement. When a trial judge believes that settlement is likely with certification, she has little incentive to decertify the class. Accordingly, defendants have little incentive to file motions to decertify, with the result that there should be few such motions and a high settlement rate-predictions consistent with the available data. ${ }^{18}$

Moreover, as we have seen, the high costs of class litigation after the certification stage create considerable pressure to settle early. And if the case settles soon after certification, the trial judge never gets a chance to revisit the initial certification decision. It follows then that initial certification is, as a practical matter, tantamount to final certification for most cases. $^{190}$

c. Settlement and the cost of erroneous certification. Proposition $2 b$ supposes that the cost of a false grant of certification is not very high compared to the cost of a false denial. The cost of a false grant is just the cost of managing the class action between the initial erroneous certification and later correction, but the cost of a false de-

188. The 1995 Federal Judicial Center study of class actions in four federal districts found that motions to decertify or reconsider a certification decision were filed in only fifteen percent of the 152 certified class actions studied, WILLGING ET AL., supra note 31, at 175 tbl. 32, and that judges modified or reversed their certification decisions in only three of these cases. Id. The net result is that judges alter their certification decisions in only two percent of certified class actions.

189. See id. (reporting motions in only twenty-three of 152 class actions studied).

190. E.g., In re VISA Check/MasterMoney Antitrust Litig., No. 00-7699, 2001 U.S. App. LEXIS 22480, at *57, *69-*71 (2d Cir. Oct. 17, 2001) (Jacobs, J., dissenting); Szabo v. Bridgeport Machs., Inc., 249 F.3d 672, 675-76 (7th Cir. 2001). Because of these costs and judicial reluctance to reverse a certification, rational defendants are not likely to hold out long enough to file a decertification motion, and the remote chance of decertification should have little effect on the settlement. 
nial is the social loss associated with frustrating the class action's important social policies.

The high frequency of settlement dramatically changes this simple analysis. With settlement likely and reconsideration of a certification decision highly improbable, the cost of false grants of certification must be measured in terms of likely settlement effects. ${ }^{191}$ This is important because erroneous certifications can lead to bad settlements that produce skewed incentives and substantial social losses.

As we saw above ${ }^{192}$ the Eisen rule's generous approach to certification and lack of attention to the merits make the class action an attractive vehicle for frivolous suits. Frivolous litigation generates social costs wherever it exists, but these costs are particularly acute in the class action setting because the scale of the class action magnifies the adverse effects. In particular, frivolous suits waste social resources, and their settlement can skew incentives in socially undesirable ways-a particularly troubling prospect in large class actions where a single settlement can cover thousands, even hundreds of thousands, of frivolous suits. Companies are deterred from engaging in socially beneficial activities for fear of being targeted. Moreover, high stakes class litigation can threaten to bankrupt a socially valuable firm. And the time spent dealing with frivolous cases harms companies by diverting valuable management resources from more productive uses.

A prime example of a frivolous suit leading to an enormous settlement is the breast implant litigation against Dow Corning and other manufacturers. ${ }^{193}$ These suits alleged that leakage from implants caused immunological and other disorders. ${ }^{194}$ After the Food and Drug Administration banned silicone gel implants for cosmetic purposes and plaintiffs' groups and the media publicized the issue, a large

\footnotetext{
191. Also, a false grant can harm absent class members if the named plaintiffs are not typical or adequate class representatives and the case settles or loses at trial with preclusive effects for the entire class. See Gilchrist v. Bolger, 733 F.2d 1551, 1556 n.4 (11th Cir. 1984) (suggesting that a class representative who failed to establish a specific pattern of discrimination in her individual case might produce an inappropriate result for other class members).

192. See supra Part III.D.2.

193. For a more detailed account of the events briefly summarized here, see generally David E. Bernstein, The Breast Implant Fiasco, 87 CAL. L. REV. 457 (1999) (reviewing MARCIA Angell, Science on Trial: The Clash of Medical Evidence and the LaW in the Breast ImPlant CaSe (1996)); Laurens Walker \& John Monahan, Scientific Authority: The Breast Implant Litigation and Beyond, 86 VA. L. REV. 801 (2000) (discussing the uses of scientific panel results in breast implant litigation and other mass tort cases).

194. In re Silicone Gel Breast Implant Prods. Liab. Litig., Nos. CV92-P-10000-S, CV94-P11558-S, 1994 U.S. Dist. LEXIS 12521, at*3 (N.D. Ala. Sept. 1, 1994).
} 
number of women brought suit against Dow Corning and other manufacturers. The Judicial Panel on Multidistrict Litigation transferred these suits, and the transfer order eventually resulted in over 21,000 cases being consolidated in the Northern District of Alabama. ${ }^{195}$ The manufacturers ultimately settled all the cases for more than four billion dollars, but the settlement collapsed after more women asserted claims on the settlement fund than the parties had anticipated. In the end, Dow Corning had to declare bankruptcy. ${ }^{196}$

At the time of these events, plaintiffs lacked credible scientific support for their medical theories, and since that time, additional medical studies have cast serious doubt on their allegations. ${ }^{197}$ These studies have shown, for example, that immunological disorders are no more common in women with breast implants than in those without them. ${ }^{198}$ Indeed, since the class action settlement, at least one court has found that the plaintiffs' proffered scientific testimony should be excluded. ${ }^{199}$

The breast implant settlement took place in the context of a settlement class action aimed at achieving a global resolution of all the claims, and Dow Corning sought the settlement to avoid the potentially crippling liability of class and individual litigation. Yet the case provides a good illustration of how frivolous lawsuits (as defined here) can lead to large settlements and of the need to have a review of the merits at an early enough stage to detect cases that lack sufficient foundation to go forward.

In sum, an erroneous certification decision can encourage substantial settlements in frivolous class action suits, and it can also enhance the plaintiffs' settlement leverage and litigating power in meritorious suits that should not be certified. The magnitude of these effects will vary with the particular circumstances of the class action

195. Walker \& Monahan, supra note 193, at 805.

196. Id. at 806.

197. See Bernstein, supra note 193, at 459-64 ("[P]laintiffs in the breast implant litigation never presented any sound scientific evidence that implants cause systemic diseases such as cancer and connective-tissue diseases caused by immune-system malfunctions.”).

198. Not only have medical studies demonstrated no causal link between breast implants and the disorders the plaintiffs complained about, see id. at 480-84 (discussing the findings of epidemiological studies), but a panel of distinguished scientists appointed by the Alabama federal district judge in the consolidated proceeding found "no sufficient scientific basis to link silicone implants to either connective tissue diseases or immune system dysfunctions," Walker \& Monahan, supra note 193, at 810, and a later report by the Institute of Medicine of the National Academy of Sciences came to the same conclusion, id. at 812.

199. Hall v. Baxter Healthcare Corp., 947 F. Supp. 1387, 1392, 1414-15 (D. Or. 1996). 
suit, including the degree of the defendant's risk aversion, the estimate of potential class-wide liability, cash flow constraints, agency dynamics, reputation costs, and the like. But for our purposes it is enough to note that the cost of erroneous certifications is much more serious than Proposition $2 b$ assumes.

d. The cost of erroneous certification denials. Proposition $2 \mathrm{~b}$ also assumes that a failure to certify will scuttle the class action altogether. This assumption is what justifies the claim that erroneous denials of certification are likely to be very costly. However, the assumption is wrong as to most class actions. The consequences of a false denial are much less serious than Proposition $2 \mathrm{~b}$ assumes.

To see why, we must distinguish between three different categories of class action. The first category includes (b)(3) and (b)(2) class actions with claims large enough to justify individual suits. The second category includes (b)(1) class actions with cost-justified individual suits that risk creating serious externalities. And the third category includes (b)(3) class actions with small claims insufficient to support individual suits. This classification scheme tracks the most common functional divisions among class actions. The difference between class actions with large claims and those with small claims is that for large claims, a false denial does not prevent the plaintiffs from obtaining relief through individual litigation, while for smaller claims it can. So too, the reason for isolating those class actions designed to avoid serious externalities has to do with the adverse consequences of an erroneous certification denial in such cases.

i. Cost-justified (b)(3) and (b)(2) suits. When class members have enough at stake to justify litigating individual suits, an erroneous denial of certification does not prevent enforcement of the substantive law. It merely leaves the named plaintiffs and absent class members free to proceed with individual litigation apart from a class action.

Moreover, an erroneous denial of certification does not necessarily doom the class action completely. For one thing, the named plaintiffs, if they continue with their individual suits, might be able to obtain later reconsideration of a negative certification decision when more information is available. ${ }^{200}$ Also, since a denial of certification

200. Rule 23(c)(1)'s certification timing requirement might get in the way, but there is no sound reason not to certify later if no one is prejudiced by the delay. It seems reasonable, how- 
has no preclusive effect on absent class members not in privity with the named plaintiffs,${ }^{201}$ it is open to a later court to certify a class action in a suit brought by an absent class member-if intervening events show that the earlier denial of certification was erroneous. ${ }^{202}$

Thus, the cost of a false denial for the first category of class actions is mainly the public and private cost of litigating the first few suits on an individual basis-not the much greater cost of preventing substantive law enforcement altogether or even of scuttling a class action. Furthermore, this cost is offset to some extent by the benefits of individual litigation. For example, if plaintiffs prevail in their individual suits, the class might be able to use offensive issue preclusion against the common defendant to avoid duplicative litigation in the later class suit. ${ }^{203}$ Moreover, litigation of a few individual suits will supply information that should be useful for reducing transaction costs and facilitating successful settlement bargaining in a later class suit. $^{204}$ To be sure, the class action helps plaintiffs spread litigation costs, but plaintiffs can achieve some of these benefits through voluntary joinder on a smaller scale or through litigation committees and other informal modes of cooperation.

ever, to suppose that a judge would be reluctant to certify after the individual suits have progressed substantially toward trial.

201. See Rhonda Wasserman, Dueling Class Actions, 80 B.U. L. REV. 461, 484-85 (2000) (noting that "because only parties or their privies are bound by decisions against them and because absent class members are not bound by decisions entered in class litigation until the class is certified, an order denying certification ordinarily will not be binding" in class actions filed by different class representatives); see also J.R. Clearwater, Inc., v. Ashland Chem. Co., 93 F.3d 176, 179 (5th Cir. 1996) ("Accordingly, it seems apparent to us that the denial of class certification similarly lacks sufficient finality to be entitled to preclusive effect while the underlying litigation remains pending.").

202. Indeed, the Fifth Circuit Court of Appeals assumed just this when it held that class certification in Castano was premature. Castano v. Am. Tobacco Co., 84 F.3d 734, 752 (5th Cir. 1996).

203. See Parklane Hosiery Co. v. Shore, 439 U.S. 322, 331 (1979) (concluding that federal courts should not preclude the use of offensive collateral estoppel but should grant trial courts broad discretion to determine when it should be applied). But see Hardy v. Johns-Manville Sales Corp., 681 F.2d 334, 337 (5th Cir. 1982) (refusing to allow offensive issue preclusion).

204. This assumes that information available to the attorneys in individual suits also will be available to the attorney in the class suit. This is a reasonable assumption as there is a great deal of overlap in legal representation of class members and considerable informal sharing of information among lawyers. See, e.g., Howard M. Erichson, Informal Aggregation: Procedural and Ethical Implications of Coordination Among Counsel in Related Lawsuits, 50 DUKE L.J. 381, 386-408 (2000) (describing the pervasive nature of informal coordination and information sharing among lawyers). 
ii. Cost-justified (b)(1) suits. The second category of class action includes those suits for which certification is sought under subdivision (b)(1) of Rule 23, and sometimes under subdivision (b)(2) when it involves similar concerns, such as a risk that individual suits will produce conflicting decrees imposing inconsistent obligations on the defendant. ${ }^{205}$ In these cases, a class action is authorized because individual lawsuits risk imposing serious externalities on the defendant or other class members. For example, certification under (b)(1) is allowed in "limited fund" situations, in which the defendant's assets are insufficient to satisfy all the claims and a class action allows for an equitable distribution of the fund. ${ }^{206}$ Also, certification is allowed under (b)(1) - and sometimes under (b)(2) - in situations where the defendant faces a risk of inconsistent judicial decrees if class members sue separately. ${ }^{207}$

These class actions, like those in the first category, involve class members who have enough at stake to justify individual litigation; otherwise, there would be no reason to worry about externalities since there would be no individual suits. However, a false denial of certification is potentially more serious for these cases than for cases in the first category. The reason is that individual litigation may create the very externalities that the class action was meant to prevent.

Still, a false denial no more precludes all class actions in these cases than it does in the first category. It is still possible for a court to certify a class in a later suit, after there has been some individual litigation by class members. Moreover, the social cost of tolerating individual suits depends on the kind of externality at stake. In "limited fund" situations under subdivision $(b)(1)(B)$, a few individual suits

205. Certification sometimes is granted under Rule 23(b)(2) because an injunction is the primary form of relief even though the case also presents externality risks that would qualify it under (b)(1). For example, civil rights class actions seeking broad structural relief usually are certified under (b)(2), but they also might qualify under (b)(1) because of the risk that individual suits could generate incompatible decrees. See generally 7A WRIGHT, MiLler \& KANE, supra note $3, \S 1775$, at 489 (noting that actions under (b)(2) may also qualify under (b)(1) or (b)(3)).

206. See Arthur R. Miller, An Overview of Federal Class Actions: Past, Present, and Future, 4 JUST. SYS. J. 197, 211 (1978) (arguing that individual cases should be converted into a class action when there are multiple claimants to a limited fund such as insurance proceeds or trust assets).

207. See, e.g., Reynolds v. Nat'l Football League, 584 F.2d 280, 283-84 (8th Cir. 1978) (noting the propriety of allowing certification under Rule 23(b)(1) to avoid inconsistent adjudication). 
should not present a serious problem unless the fund is extremely limited. ${ }^{208}$

Incompatible decrees present a potentially more serious problem. If a judge orders broad injunctive or declaratory relief in an individual suit, other judges could end up issuing inconsistent decrees in subsequent suits or in a later class action. However, this scenario should not be terribly common. ${ }^{209}$ Often the same lack of commonality that prevents certification of a class also will prevent broad relief in an individual suit, thereby eliminating any risk of incompatible decrees. For example, certification of a single company-wide class challenging employment discrimination across the board is proper only if the discrimination has a common thread at the company level. ${ }^{210}$ Without such commonality, any challenge must target practices at a lower level of the company, such as department-by-department or supervisor-by-supervisor. In such a case, the proper scope of injunctive relief also would be narrowly tailored to the localized wrong. Moreover, if it appears from these targeted lawsuits that a common thread in fact exists, the judge always can reconsider his earlier certification denial and correct his error.

Even so, when a false denial results in different courts entering contradictory decrees, the social costs can be quite high. For this reason, it might be wise to indulge a somewhat more generous approach to certification when the risk of contradictory decrees is substantial. A court still would examine merits-related evidence rigorously, but it also might recognize a presumption in favor of certification and certify on a somewhat lower threshold probability of success to reduce the risk of false denials.

208. And if the fund is extremely limited, this fact should be relatively easy to prove, so a judge is not likely to make an error in evaluating the merits for purposes of calculating an expected value for the class claims and determining whether the fund is actually limited.

209. The cases that pose the most serious risks tend to fit into paradigmatic situations; for example, civil rights suits seeking structural injunctive relief, or constitutional challenges to corporate, municipal, or state action. Therefore, the risk of incompatible decrees usually should be apparent from the outset, so the likelihood of a false denial should be quite small.

210. See supra note 59-60 and accompanying text. At least insofar as they are limited to injunctive and declaratory relief, class actions challenging employment discrimination usually are certified under Rule 23(b)(2) rather than Rule 23(b)(1)(A). 7A WRIGHT, MILLER \& KANE, supra note 3, § 1776, at 495-96; see also Kyriazi v. W. Elec. Co., 647 F.2d 388, 393 (3d Cir. 1981) ("A class action seeking declaratory and injunctive relief from a pattern or practice of employment discrimination in violation of Title VII is obviously the paradigm of a Rule 23(b)(2) class action."). However, the point is the same no matter what subdivision is used for certification. 
iii. Small-claim (b)(3) suits. Class actions with small claims that are certified under subdivision (b)(3) present a different situation. In these cases, the class action solves a collective action problem. ${ }^{211}$ By bringing a class action, the class attorney is able to aggregate all the small claims into a single lawsuit with enough at stake to make litigation profitable. Thus, the adverse consequences of an erroneous denial of certification may seem quite significant at first glance. Because by assumption class members have too little at stake to bring individual suits, denial of certification can frustrate private enforcement of the substantive law.

The cost of false denials, however, is not likely to be so serious. The main purpose of the small-claim class action is deterrence, not compensation. Typically, class members have too little at stake to make individual compensation a significant private or public objective given the enormous social costs of class litigation. ${ }^{212}$ Instead, the class action empowers the class attorney as a private attorney general to internalize the social costs of defendant's acts and deter wrongdoing. ${ }^{213}$

A reasonable level of deterrence can be achieved even with a significant risk of erroneous certification denials. For one thing, the deterrent effect of the class action is a function of its litigation costs as

211. See generally Jonathan R. Macey \& Geoffrey P. Miller, The Plaintiffs' Attorney's Role in Class Actions and Derivative Litigation: Economic Analysis and Recommendations for Reform, 58 U. CHI. L. REV. 1 (1991) (recommending new policies to regulate large-scale, smallclaim litigation).

212. See, e.g., HENSLER ET AL., supra note 34, at 68-72 (focusing on the deterrence objective). This is not to say that compensation has no social value at all; rather, its value is so small given the small stakes that the deterrence goal dominates. Put another way, it is extremely unlikely that the class action would be allowed at all for small claims without the deterrence rationale. It is true that total damages for the class as a whole can be enormous, but compensation should be evaluated on an individual, not an aggregate, basis. Because the class is not an organized entity capable of benefiting collectively from an aggregate recovery, the only sensible way to assess the social value of compensation is in terms of the benefit to each class member individually, and that benefit is typically quite small. But see David L. Shapiro, Class Actions: The Class as Party and Client, 73 Notre DAme L. ReV. 913, 924-25, 956 (1998) (arguing that the small-claimant class should be viewed as an entity).

213. See Macey \& Miller, supra note 211, at 8-11 (arguing that the class action suit provides an effective and inexpensive procedure for joining large numbers of plaintiffs). For example, the attorney for the class in a securities fraud class action can look forward to receiving a large fee as a proportion of the aggregate class recovery if the suit succeeds. This creates a substantial incentive for the attorney to sue and hold firms legally accountable, which in turn creates a deterrent effect. 
well as the expectation of liability it generates. ${ }^{214}$ Consider a firm deciding whether to engage in conduct that might violate the law and create widely dispersed and relatively small injuries to a large number of individuals. The firm will consider the potential risk of liability and discount this risk by the probability of an erroneous certification denial. However, the firm also will consider the litigation cost of a class action if one is certified. As long as there is a sufficiently high probability of class certification, the firm will choose to comply with the law even when it anticipates a less than perfectly accurate certification procedure, rather than risk having to pay for class action litigation in the event a class is certified. ${ }^{215}$

In addition, the class action is not the only deterrence device for cases involving small claims; deterrence also can be achieved through public enforcement. For example, the Securities Exchange Commission has power to enforce the federal securities laws, the Federal Trade Commission has power to enforce the antitrust laws, and federal agencies and state attorneys general have power to enforce federal and state consumer protection laws. ${ }^{216}$ To be sure, public enforcement is limited by budgetary and legal constraints, and for this reason, private enforcement through the class action is thought to be a valuable supplement. Still, it is important to bear in mind that the class action need not do all the deterrence work by itself.

Finally, the fact that many small-claimant classes include a few members with large claims also mitigates the adverse effect of false certification denials. For example, a securities fraud class often has a few, and sometimes quite a few, large institutional investors with

214. However, the high rate of class action settlement can reduce this deterrent effect insofar as the defendant saves litigation costs when the case settles. In an extreme case-where litigation costs are the same for the class and the defendant, the probability of success and likely judgment are common knowledge, and the surplus is split equally-the defendant ends up paying nothing in litigation costs. See A. Mitchell Polinsky \& Daniel L. Rubinfeld, The Deterrent Effects of Settlements and Trials, 8 INT'L REV. L. \& ECON. 109, 114 (1988) (examining the deterrent effect of litigation costs as well as liability).

215. This assumes, of course, that substantive rules of liability and remedy have not already been adjusted to account for the deterrent effect of litigation costs. To formalize the point, let $w$ be the probability of certification, let $p$ be the probability that the class attorney will win the suit if a class is certified, let $x$ be the expected judgment if the class wins, and let $c_{D}$ be the cost to the defendant of litigating a class action. Assuming that the class action is the only vehicle for holding the firm accountable, then the potential cost to the firm is: $w\left(p x+c_{D}\right)=w p x+w c_{D}$. If $p x$ is the ideal amount of cost internalization (i.e. where $w=1$, and $c_{D}$ does not figure in the choice of substantive rules that determine $p$ and $x$ ), then the ideal is achieved for a value of $w$ less than 1 ; i.e. at $w=p x /\left(p x+c_{D}\right)$.

216. In addition, criminal penalties can be imposed for particularly egregious violations. 
enough at stake to justify individual suits. ${ }^{217}$ Their presence has two important implications. First, even if a class action is erroneously denied, there is still a possibility of a partial deterrence benefit if large claimants bring individual suits. ${ }^{218}$ Second, an erroneous denial of certification need not doom the class action completely. If institutional investors bring individual suits, an enterprising attorney can rely on the information developed in those suits to try for certification again in a later class action limited to the small claims. ${ }^{219}$

Therefore, in the third category of class actions-(b)(3) damages suits involving only (or mainly) small claims - the cost of false certification denials is in fact much less serious than Proposition $2 b$ assumes. The main function of the class action for small claims is deterrence, and substantial deterrence benefits can still be achieved even with a significant risk of false denials. ${ }^{220}$

217. See William B. Rubenstein, A Transactional Model of Adjudication, 89 GEO. L.J. 371, 395-400 (2001) (collecting data on the prevalence of institutional investors, and noting that the Private Securities Litigation Reform Act of 1995 assumes that institutional investors will play a substantial role in securities fraud class litigation); Weiss \& Beckerman, supra note 158, at 208894 (examining the prevalence of institutional investors in class action suits). Moreover, antitrust class actions also can include class members with very large claims. For example, the VISA Check/MasterMoney antitrust class action includes a large number of merchants with relatively small claims, but also some with damage claims that are likely to total in the hundreds of millions of dollars. Indeed, the named plaintiffs include large, well-financed corporations such as Wal-Mart, The Limited, Sears-Roebuck, and Circuit City. In re VISA Check/MasterMoney Antitrust Litig., No. 00-7699, 2001 U.S. App. LEXIS 22480, at *72 (2d Cir. Oct. 17, 2001) (Jacobs, J., dissenting) (noting that "de-certification would not doom this litigation" because of the presence of large claims and estimating that Wal-Mart's recovery could "reach a quarter billion dollars (with trebling and before attorneys' fees) for 1999 alone").

218. It is true that large institutional investors have in the past been reluctant to act as class representatives in securities fraud class actions because of the litigation burden, the adverse publicity and reputation effects, and other factors. Weiss \& Beckerman, supra note 158, at 2095105. But institutional investors are taking a more active role in class litigation since enactment of the Private Securities Litigation Reform Act. Rubenstein, supra note 217, at 398. And in any event, without a class action in which to hide, one would expect institutional investors to sue individually when they suffer substantial losses.

219. This strategy is limited to some extent by free-rider problems. If there is more than one large institutional investor, for example, each investor might choose not to file in the hope that one of the others files first.

220. In addition to the error-cost argument criticized in the text, there is another reason that a judge might certify a class action without inquiring into the merits of the competing claims. $\mathrm{He}$ simply might disagree with the policy choices embodied in Rule 23 or the substantive law and seek to circumvent those choices by granting class certification even when plaintiffs are not entitled to recover or to bring a class action under the applicable law. In this situation, the judge chooses to ignore the merits not because a preliminary determination is too difficult or too prone to error, but instead because it is likely to produce a result in the defendant's favor, which is at odds with the judge's preferred outcome. Whether the judge is correct as a policy matter is irrelevant; he has a duty to apply Rule 23 and the substantive law as they exist and not circum- 
e. Summary of Proposition 2 analysis. Combining the different strands of the previous analysis, we can make the following rough assessment of Proposition 2. First, for (b)(3) class actions involving large claims, especially mass torts, the relative cost of the two errors is probably just the opposite of what Proposition 2 states. In these cases, the cost of a false grant of certification is the social cost of a settlement leveraged improperly through the power of the class action, whereas the cost of a false denial is mostly just the net cost of litigating a few individual suits.

The error-cost comparison for (b)(3) class actions involving small claims is less certain. The cost of a false grant is still the cost of an improperly leveraged settlement, but the cost of a false denial is the cost of denying a remedy to deserving claims (at least if there is no other opportunity to form a class). Still, because the class action in these cases is mainly about deterrence and because deterrence can be achieved without perfect accuracy at the certification stage, the cost of false denials is likely to be much lower than Proposition $2 \mathrm{~b}$ assumes.

It is only in the case of (b)(1), and to some extent (b)(2), class actions involving potentially inconsistent decrees that we can say with some confidence that Proposition 2 is likely to hold true. A false denial risks reducing the benefits of the class action by opening up the possibility of inconsistent relief. Even so, the seriousness of this problem is reduced to a large extent by the fact that the risk of error is quite small in these cases and the most problematic situations are not all that likely to arise.

3. The Flaws in Proposition 3. To recap the discussion so far, we set out in this Section to show that the error-cost argument for the Eisen rule is flawed, and that, properly understood, it supports a stricter review of the merits at the certification stage. We started by breaking the error-cost argument into three propositions. We saw that Proposition 1 (Rule E reduces false denials but increases false grants) is valid, but that Proposition 2 (a false denial is more costly than a false grant) is flawed. Because of the high incidence of settle-

vent their prescriptions by subterfuge. Policy questions like these should be decided centrallythrough the formal rulemaking process established by the Rules Enabling Act in the case of Rule 23, and through the legislative process in the case of substantive antitrust law. See generally Robert G. Bone, The Process of Making Process: Court Rulemaking, Democratic Legitimacy, and Procedural Efficacy, 87 GEO. L.J. 887 (1999) (advocating a centralized and uniform rulemaking process for important procedural rules). 
ment in class actions, a decision to certify a class is likely to be final rather than provisional-contrary to Proposition 2a. Moreover, Proposition $2 \mathrm{~b}$ exaggerates the costs of false certification denials and underestimates the cost of false grants.

These points taken together challenge the conclusions of Proposition 3. To see why, let us return to the hypothetical choice between Rule E (the pure Eisen rule) and Rule N (our proposed alternative). Let us make the additional assumption-a modest one given the previous analysis - that false grants of certification and false denials are equally costly. If we can show that Rule $\mathrm{N}$ is superior when the two kinds of error create the same cost, then a fortiori it must be superior when the cost of false certification grants is higher.

When error costs are equal, the choice between Rule E and Rule $\mathrm{N}$ turns solely on the total number of errors each rule is likely to create, and Rule E is likely to create more errors than Rule N. The intuition is easy to state. Rule $\mathrm{E}$ creates a high risk of false grants by indulging a generous approach to certification. With a generous approach, Rule E also creates additional incentives for plaintiffs to file frivolous class action suits. The combination of these two factors-a high rate of erroneous certifications and a large number of frivolous class action suits-means that Rule E produces a large total number of errors.

Rule N, on the other hand, substantially reduces the risk of false grants and with it the incentive to file frivolous suits. Of course, Rule $\mathrm{N}$ also increases the risk of false denials, and this additional risk might also discourage the filing of some meritorious certification motions. But these adverse effects should not be serious. The availability of precertification discovery coupled with careful judicial review at the certification stage should keep the number of false denials in check, unless there is some special reason to worry about limited information access or cognitive bias. Moreover, a relatively small risk of false denials should have little impact on the filing of meritorious certification motions given the considerable benefits of class certification.

Therefore, Rule E increases false grants and invites more frivolous filings, two effects that combine to produce a large total number of errors, whereas Rule $\mathrm{N}$ mostly just adds to the risk of false denials, a marginal effect limited by an overall improvement of accuracy at the certification stage. As a result, Rule $\mathrm{E}$ is likely to produce more total errors than Rule $\mathrm{N}$ under almost all plausible factual scenarios.

To illustrate, consider the following hypothetical. The numbers in this hypothetical are fictional, but they have been chosen to be 
consistent with the incentive analysis and limited empirical data discussed in previous Sections. Moreover, we show at the conclusion of our discussion that the same results hold true under a wide range of numerical assumptions. ${ }^{221}$

Suppose that when Rule E is in effect it attracts frivolous class action suits, so that $30 \%$ of the cases filed as class actions are in fact frivolous in the sense that they should not be certified. ${ }^{222}$ Suppose as well that in using Rule E a judge grants certification $70 \%$ of the time when the case is one that in fact should not be certified and denies certification $10 \%$ of the time when the case is one that in fact should be certified. ${ }^{223}$

By contrast, when using Rule N, a judge erroneously grants certification much less often-assume $20 \%$ of the time-and because Rule N's stricter approach deters frivolous filings, the fraction of frivolous class actions drops-say, from $30 \%$ to $15 \%$. At the same time, however, Rule $\mathrm{N}$ increases the risk of erroneous denials-assume that the risk doubles from $10 \%$ to $20 \%$. This reflects the stricter approach of Rule N, and also the salutary impact of limited precertification discovery and careful judicial review. And for simplicity, assume that Rule $\mathrm{N}$ does not discourage the filing of meritorious class actions. ${ }^{224}$

On these assumptions, it is easy to show that Rule $\mathrm{N}$ is superior to Rule E on error-cost grounds when the two errors have the same cost. The table below shows the probability of error under each rule. This probability is the risk that the court will commit a particular type of error (a false grant or a false denial) discounted by the probability that the case will be one for which the particular kind of error is possible. For example, what we label "false grant probability" equals the risk of an erroneous certification multiplied by the fraction of class action suits that in fact should not be certified. ${ }^{225}$

221. See infra notes 226-31 and accompanying text.

222. The thirty percent figure is reasonable given Rule E's laxity and consistent with the analysis of frivolous litigation incentives in Part III.D.2.

223. These assumptions reflect the fact that Rule E forbids consideration of the merits and indulges a strong presumption in favor of certification.

224. This last assumption is quite plausible, but it is also unnecessary to the results. In fact, Rule N remains superior even when it deters some meritorious filings. See infra note 229 and accompanying text.

225. Thus, the table reflects the fact that the total number of false grant (false denial) errors depends not only on the false grant (false denial) error risk but also on the number of cases in which the particular kind of error can occur. For example, if plaintiffs filed only certifiable class actions, there never would be any possibility of a false grant. More precisely, the risk of false 
ERROR PROBABILITIES

\begin{tabular}{|l|c|c|}
\hline & RULE E & RULE N \\
\hline False grant probability & $0.7 \times 0.3=0.21$ & $0.2 \times 0.15=0.03$ \\
\hline False denial probability & $0.1 \times 0.7=0.07$ & $0.2 \times 0.85=0.17$ \\
\hline Total probability of error & 0.28 & 0.20 \\
\hline
\end{tabular}

Thus, Rule $\mathrm{N}$ is superior because it produces a lower total probability of error (20\%) than Rule E (28\%). This result holds true over a wide range of different values for the parameters. For example, Rule $\mathrm{N}$ remains superior even when the risk of a false grant under Rule E drops from $70 \%$ to $50 \%$ (with all other variables held constant), ${ }^{226}$ and also when the background fraction of frivolous class action suits falls from $30 \%$ to $20 \%$ (again with all other variables held constant). ${ }^{227}$ Moreover, fixing the background fraction of frivolous class action suits at $40 \%$, Rule $\mathrm{N}$ remains superior even if Rule $\mathrm{E}$ eliminates absolutely all false denials-as long as Rule E also produces false grants with a probability in excess of $50 \% .{ }^{228}$ Finally, Rule

grants (false denials) in the hypothetical is a conditional probability, whereas the label "false grant probability" ("false denial probability") in the table denotes an unconditional probability.

226. When the false grant probability is at $50 \%$, the table looks like this:

\begin{tabular}{|l|r|r|}
\hline & RULE E & \multicolumn{1}{|c|}{ RULE N } \\
\hline False grant probability & $0.5 \times 0.3=0.15$ & $0.2 \times 0.15=0.03$ \\
\hline False denial probability & $0.1 \times 0.7=0.07$ & $0.2 \times 0.85=0.17$ \\
\hline Total probability of error & 0.22 & 0.20 \\
\hline
\end{tabular}

227. When $20 \%$ of the class actions are frivolous, the table looks like this:

\begin{tabular}{|l|r|r|}
\hline & RULE E & \multicolumn{1}{|c|}{ RULE N } \\
\hline False grant probability & $0.7 \times 0.2=0.14$ & $0.2 \times 0.15=0.03$ \\
\hline False denial probability & $0.1 \times 0.8=0.08$ & $0.2 \times 0.85=0.17$ \\
\hline Total probability of error & 0.22 & 0.20 \\
\hline
\end{tabular}

228. If the conditional probability of a false grant under Rule $\mathrm{E}$ is 0.5 and the conditional probability of a false denial is 0.0 , then the error risk table looks like this:

\begin{tabular}{|l|r|r|}
\hline & RULE E & \multicolumn{1}{|c|}{ RULE N } \\
\hline False grant probability & $0.5 \times 0.4=0.20$ & $0.2 \times 0.15=0.03$ \\
\hline False denial probability & $0.0 \times 0.6=0.00$ & $0.2 \times 0.85=0.17$ \\
\hline Total probability of error & 0.20 & 0.20 \\
\hline
\end{tabular}


$\mathrm{N}$ remains superior even if the risk of false denials adversely affects filing incentives in meritorious class actions. ${ }^{229}$

Again, the specific numbers in this hypothetical are not particularly important. We chose them simply to illustrate how easy it is for Rule $\mathrm{N}$ to end up as the better choice. ${ }^{230}$ Certainly, Rule $\mathrm{N}$ is not al-

229. The error risk analysis is more complicated under these conditions. To take account of effects on filing incentives, one must focus on potential class action suits, that is, suits that could be class actions but have not yet been filed, and consider how many of those potential suits will be filed under each rule. To illustrate, suppose that $30 \%$ of potential class actions are frivolous and $70 \%$ are meritorious. Suppose that Rule E's generous approach to certification encourages everyone with a potential class action to file. Furthermore, suppose that Rule N's stricter approach has a deterrent effect on both frivolous and meritorious filings, so that frivolous class actions are filed only $40 \%$ of the time and meritorious class actions only $80 \%$ of the time (i.e., $20 \%$ are deterred). These figures are probably high, but they are chosen to make the toughest case for Rule N. Assume that false grant and false denial error probabilities are the same as in the original example (i.e., $70 \%$ and $10 \%$ respectively for Rule E, and $20 \%$ and $20 \%$ respectively for Rule N).

The new element in the analysis has to do with the calculation of false negative probability under Rule N. There are now two ways that a false negative can arise: by the court failing to certify a meritorious class action (a false denial) or by a plaintiff failing to file. Nevertheless, Rule $\mathrm{N}$ is still the superior choice. The new error risk table looks like this:

\begin{tabular}{|l|r|r|}
\hline & \multicolumn{1}{|c|}{ RULE E } & \multicolumn{1}{c|}{ RULE N } \\
\hline False grant probability & $0.7 \times 0.30=0.21$ & $0.2 \times 0.4 \times 0.3=0.024$ \\
\hline False denial or nonfiling probability & $0.1 \times 0.70=0.07$ & $0.2 \times 0.8 \times 0.7+0.2 \times 0.7=0.252$ \\
\hline Total probability of error & 0.28 & 0.276 \\
\hline
\end{tabular}

230. In fact, Rule $\mathrm{N}$ still can be the better choice even when the cost of a false denial exceeds the cost of a false grant. To illustrate, suppose that under Rule E, $50 \%$ of the cases filed as class actions are in fact not certifiable. Suppose also that courts using Rule E grant certification erroneously $70 \%$ of the time and deny certification erroneously $10 \%$ of the time. Further, when courts apply Rule N, they mistakenly grant and deny certification with the same probability, $20 \%$, and the fraction of class actions that are not certifiable drops to $30 \%$. (Also assume for simplicity that Rule $\mathrm{N}$ does not deter meritorious filings.) The error risk table looks like this:

\begin{tabular}{|l|c|c|}
\hline & RULE E & RULE N \\
\hline False grant probability & $0.7 \times 0.5=0.35$ & $0.2 \times 0.3=0.06$ \\
\hline False denial probability & $0.1 \times 0.5=0.05$ & $0.2 \times 0.7=0.14$ \\
\hline
\end{tabular}

Here we cannot simply add the false grant and false denial probabilities, as we did with the other hypotheticals, because false grant and false denial error costs are not necessarily equal. Yet it is easy to see from the table that Rule $\mathrm{N}$ is the superior choice even when false denials are more costly than false grants. Indeed, false denials can be three times as costly. For in that case, the total expected error cost for Rule $\mathrm{E}$ (normalizing a false grant cost to 1 ) is: $0.35+0.05 \times 3=$ 0.50 . And the total expected error cost for Rule N is: $0.06+0.14 \times 3=0.48$. 
ways superior, but the factual scenarios in which it is superior are far more probable than those in which it is not. ${ }^{231}$

\section{E. The Process-Cost Argument}

Error costs are not the only kind of costs that matter for evaluating a procedural rule. Any cost-benefit analysis must take account of process costs as well. Process costs include litigation, opportunity, and other private costs that parties actually incur in litigating a case, as well as the public cost of supporting the court system.

Applied to our choice between Rule E and Rule N, the processcost argument is fairly straightforward. Rule E should not be very costly to administer because it avoids a burdensome inquiry into the merits. Rule N, on the other hand, requires that the parties expend

231. This point can be analyzed mathematically as follows. Let $p_{1}$ be the background fraction of noncertifiable class action suits in a procedural world with Rule E in effect, and let $p_{2}$ be the fraction when Rule $\mathrm{N}$ is in effect. Similarly, let $r_{1}\left(r_{2}\right)$ be the probability that the judge falsely grants certification when Rule $\mathrm{E}$ (Rule $\mathrm{N}$ ) is in effect; and let $s_{1}\left(s_{2}\right)$ be the probability that the judge falsely denies certification when Rule $\mathrm{E}$ (Rule $\mathrm{N}$ ) is in effect. Let $c_{G}$ be the social cost of a false grant and $c_{D}$ the social cost of a false denial. (Also assume for simplicity that Rule $\mathrm{N}$ does not deter meritorious filings.)

Rule E's expected error cost $\left(E C_{1}\right)$ equals $r_{1} p_{1} c_{G}+s_{1}\left(1-p_{1}\right) c_{D}$. Rule N's expected error cost $\left(E C_{2}\right)$ equals $r_{2} p_{2} c_{G}+s_{2}\left(1-p_{2}\right) c_{D}$. Rule $\mathrm{N}$ is superior to Rule $\mathrm{E}$ on error-cost grounds if and only if $E C_{1}>E C_{2}$; that is

Rearranging, we get

$$
r_{1} p_{1} c_{G}+s_{1}\left(1-p_{1}\right) c_{D}>r_{2} p_{2} c_{G}+s_{2}\left(1-p_{2}\right) c_{D}
$$

$$
c_{D} / c_{G}<\left[r_{1} p_{1}-r_{2} p_{2}\right] /\left[s_{2}\left(1-p_{2}\right)-s_{1}\left(1-p_{1}\right)\right]
$$

If we assume that the costs of the two errors are the same and that Rule $\mathrm{N}$ produces a symmetric error risk, then $c_{G}=c_{D}$ and $s_{2}=r_{2}$. On these assumptions, inequality (1) becomes

$$
1<\left[r_{1} p_{1}-r_{2} p_{2}\right] /\left[r_{2}\left(1-p_{2}\right)-s_{1}\left(1-p_{1}\right)\right]
$$

Rearranging and reducing gives the following condition:

$$
p_{1}>\left(r_{2}-s_{1}\right) /\left(r_{1}-s_{1}\right)
$$

It is easy to see why inequality (2) is likely to hold as a general matter. Because Rule E is meant to guard against false denials by strongly favoring certification, $s_{1}$ should be quite small and $r_{1}$ should be comparatively large. As a result, $r_{1}-s_{1}$ should be large. Assuming judges are not terribly error prone under Rule $\mathrm{N}$, it also is likely that $r_{2}-s_{1}$ is quite small. Therefore, $\left(r_{2}-s_{1}\right) /\left(r_{1}\right.$ $-s_{1}$ ) should be small. Finally, because Rule E encourages strategic filings of frivolous class action suits, $p_{1}$ is likely to be relatively large-and thus likely to exceed $\left(r_{2}-s_{1}\right) /\left(r_{1}-s_{1}\right)$, as inequality (2) requires.

232. For example, error costs could be reduced substantially by allowing ten trials instead of one and selecting the majority result on liability or the average of the ten verdicts as the final judgment in the case. See Bernard Grofman et al., Thirteen Theorems in Search of the Truth, 15 THEORY \& DECISION 261, 264-65 (1983) (discussing how iteration can improve accuracy by virtue of the Condorcet Theorem). However, the additional process costs of a ten-trial rule would be extremely high, almost certainly greater than the marginal benefit in terms of errorcost reduction. 
resources on merits-related discovery and requires the judge to spend time hearing argument and deliberating on the merits. It follows that Rule N's process costs are likely to be greater than Rule E's. If the difference is large enough, it can overwhelm Rule N's error-cost advantage. ${ }^{233}$

At first glance, it might seem that this argument exaggerates the process-cost difference between Rule E and Rule N. After all, the additional discovery required by Rule $\mathrm{N}$ probably would occur under Rule $\mathrm{E}$ in any event-just after rather than before certification. Moreover, since the defendant is likely to press its merits-related objections through a later motion to decertify or for summary judgment, Rule E will not eliminate hearing and deliberation costs; it simply will shift them to a later stage.

However, this superficial response ignores the fact that most class actions settle. Settlement avoids the usual process costs of litigating a case. Therefore, if certified class actions are likely to settle before significant discovery has taken place and before any motion to decertify or motion for summary judgment is filed, then Rule E should generate less process cost than Rule N. In other words, because Rule $\mathrm{E}$ is less costly at the certification stage, it should be less costly overall if settlement brings the case to a quick postcertification conclusion. ${ }^{234}$

Even so, two factors limit the size of the process-cost differential. First, Rule E, with its more lenient approach to certification, should attract more class action suits and thus create a need for more certification hearings. Furthermore, most of these additional suits are likely to be frivolous or marginal. As a result, under Rule E the certification

233. We separate the error-cost argument from the process-cost argument for purposes of clarity and also to allow for the possibility that process costs measured in economic units might have to be combined with error costs measured in moral units. Error costs need not be strictly financial or economic; they can be moral as well. For example, suppose that a judge erroneously denies certification of a civil rights class action and as a result the plaintiffs never obtain the broad injunctive remedy to which they were entitled. As the substance of the case involves civil rights, there is arguably more at stake than simple economic loss. The cost of the error-a failure to redress systemic discrimination — might be thought to have a moral dimension as well-at least if moral harm results when the law does not enforce important rights individuals possess as a matter of political morality. Thus, in some cases, error costs might involve a qualitative balancing of nonquantifiable moral harms. If so, then the economic costs of process would somehow have to be combined with the moral costs of error.

234. Of course, settlements can create serious problems on error-cost grounds, as we have already seen, but settlement would, according to this analysis, keep Rule E's process costs low. 
issues will be hotly contested and the cost of the additional hearings under Rule E will be higher than average.

Second, Rule E is likely to increase the process-cost burden at later stages of the litigation whenever class actions do not settle quickly after certification. For example, the more frivolous class actions there are in the system, the more occasions there are for defendants to bring summary judgment motions and the greater the process costs at the summary judgment stage. This factor might already be incorporated into the error-cost analysis if the additional litigation and administrative burden is folded into the cost of a false grant. But if not, it should be treated as an additional component of process cost. ${ }^{235}$

These two factors - a greater number of certification hearings and higher process costs at later stages-undermine the process-cost argument for Rule E. Indeed, Rule E's process costs could well be higher than Rule N's, but there is no way to be sure without more empirical evidence.

\section{F. Summary}

In sum, none of the conventional arguments-those based on the text of Rule 23, the risk of prejudice, or the importance of maintaining the substance/procedure dichotomy and preserving the integrity of the Federal Rules scheme-support continuation of the Eisen rule. More important, a careful examination of the costs and benefits favors abolishing the rule and replacing it with a rigorous review of the evidence and a preliminary evaluation of the merits at the certification stage.

To be sure, reliable empirical evidence is scarce. But when a choice must be made with limited data, the best course of action is to choose the rule that in theory is most likely to be superior-unless

235. Another point is worth mentioning. As we have seen, Rule $\mathrm{N}$ does two things: it reduces false certification grants and it also discourages the filing of frivolous class actions. Rule $\mathrm{E}$, on the other hand, does only one thing: it reduces false certification denials. It does nothing to discourage frivolous suits; indeed, it actually encourages the filing of frivolous suits. This means that if Rule $\mathrm{E}$ is adopted, frivolous class actions will have to be deterred in some other way. Whatever method is chosen will generate its own process costs, which will have to be counted in any comprehensive comparative analysis of the two rules. For example, if the procedural system opts for strict pleading and stronger Rule 11 penalties-as the Private Securities Litigation Reform Act currently does for securities fraud class actions, see 15 U.S.C. $\S 78 \mathrm{u}-4$ (2000) - then defendants will file more early motions to dismiss and more motions for sanctions. See generally A. Mitchell Polinsky \& Daniel Rubinfeld, Sanctioning Frivolous Suits: An Economic Analysis, 82 GEO. L.J. 397 (1993) (analyzing incentives to seek Rule 11 penalties when information about the merits is uncertain). 
that choice clearly is contrary to settled experience or strong and reliable anecdotal evidence. In this case, a theoretical analysis of error and process costs supports a merits review, and neither experience nor anecdote strongly contradicts this conclusion.

\section{AN EXAMPLE: CARIDAD V. METRO-NORTH COMMUTER RAILROAD}

The Second Circuit's decision in Caridad v. Metro-North Commuter Railroad ${ }^{236}$ illustrates the many failings of the Eisen rule and the advantages of an approach that considers the merits at the certification stage. The district court in Caridad denied the plaintiffs' motion to certify after considering expert evidence on a central issue. ${ }^{237}$ The Second Circuit reversed, not because it disagreed with the district court's evaluation of the evidence, but instead because it objected to the district court considering evidence at all. ${ }^{238}$ The Second Circuit held that it was impermissible for the district court to consider "statistical dueling" at the class certification stage. ${ }^{239}$ And it reached this conclusion even though the dueling was over issues that directly pertained to the certification requirements of Rule $23 .^{240}$

Caridad already has had a significant impact. So far, the opinion has been cited in eight cases in the Second Circuit as a basis for rejecting defendants' opposition to class certification. ${ }^{241}$ The most significant of these cases is In re VISA Check/MasterMoney Antitrust Litigation, ${ }^{242}$ in which the plaintiffs obtained certification of a class of four million retailers for an antitrust suit against the VISA and MasterCard associations. The district judge relied heavily on Caridad to conduct only a cursory examination of the expert evidence on the

\footnotetext{
236. 191 F.3d 283 (2d Cir. 1999).

237. Robinson v. Metro-North Commuter R.R. Co., 175 F.R.D. 46, 49 (S.D.N.Y. 1997).

238. Caridad, 191 F.3d at 292-93.

239. Id.

240. Id.

241. Doe v. Bridgeport Police Dep't, 198 F.R.D. 325, 330-34 (D. Conn. 2001); In re Magnetic Audiotape Antitrust Litig., 2001 U.S. Dist. LEXIS 7303, at *16 (S.D.N.Y. June 6, 2001); Reynolds v. Giuliani, 118 F. Supp. 2d 352, 387-92 (S.D.N.Y. 2000); Hirschfeld v. Stone, 193 F.R.D. 175, 181-82 (S.D.N.Y. 2000); In re VISA Check/MasterMoney Antitrust Litig., 192 F.R.D. 68, 78-80 (E.D.N.Y. 2000); Saddle Rock Partners, Ltd. v. Hiatt, No. 96 Civ. 9474, 2000 U.S. Dist. LEXIS 11931, at *6, *18 (S.D.N.Y. Aug. 17, 2000); Brown v. Giuliani, No. 98 Civ. 7743, 2000 U.S. Dist. LEXIS 8889, *5-*9 (S.D.N.Y. June 29, 2000); Stevelman v. Alias Research, Inc., No. 5:91-cv-682, 2000 U.S. Dist. LEXIS 9115, at*6-*7, *23-*24 (D. Conn. June 22, 2000).

242. 192 F.R.D. 68 (E.D.N.Y. 2000).
} 
certification issues ${ }^{243}$-and he did this despite expressed concern about the strength of the liability theories and the "enormous financial risks for the defendants." ${ }^{244}$ On appeal, a three-judge panel of the Second Circuit affirmed over a stinging dissent, with the majority following the district judge in relying on Caridad to bar a serious merits review. ${ }^{245}$ In addition to its direct precedential impact, Caridad also likely has had indirect effects that are much more difficult to document: discouraging serious opposition to class certification and encouraging precertification settlement. We choose Caridad as an illustration because of its importance and because one of us (Evans) was an expert witness in the case and is familiar with its details. ${ }^{246}$

\section{A. Background}

Twenty-five former employees of Metro-North Commuter Railroad Company (Metro-North) sued Metro-North for injunctive relief, compensatory and punitive damages, and attorneys' fees. ${ }^{247}$ These plaintiffs alleged that Metro-North discriminated against AfricanAmerican employees in its promotion and disciplinary decisions. ${ }^{248}$ They sought to represent a class consisting of all African-American employees of Metro-North during the period 1983 to $1996 .{ }^{249}$

243. Id. at 79, 85. The VISA court noted that Caridad was "the Second Circuit's latest word" on the question of considering the merits at the certification stage and as a result that it warranted "an extended discussion." Id. at 79.

244. Id. at 89. The district judge even went so far as to recommend that the Second Circuit take an interlocutory appeal of the certification decision:

This litigation poses enormous financial risks for the defendants, risks that are obviously increased drastically by certification of the class. Moreover, this certification motion raises substantial and novel questions involving the standards a district court should apply in evaluating a class motion and the interaction of those standards with antitrust principles.

Id.

245. In re VISA Check/MasterMoney Antitrust Litig., No. 00-7699, 2001 U.S. App. LEXIS 22480 , at $* 17-* 20$ (2d Cir. Oct. 17, 2001). Judge Jacobs, dissenting, argued that given the "coercive" settlement pressure that an erroneous certification creates, the district judge should not have certified without first being sure there was a practical means for trying the case, and he also reprimanded the district court judge for using the Eisen rule to avoid deciding how to measure injury-in-fact. $I d$. at *57-*91 (Jacobs, J., dissenting).

246. David Evans served as a statistical expert for Metro-North. National Economic Research Associates (NERA) and Evans also are consultants to VISA in the VISA Check/MasterMoney case. We should make clear, however, that this Article is the independent work of the authors and no client of NERA has contributed any funding or other assistance to the project.

248. Robinson v. Metro-North Commuter R.R. Co., 197 F.R.D. 85, 87 (S.D.N.Y. 2000).

248. Robinson v. Metro-North Commuter R.R. Co., 175 F.R.D. 46, 47 (S.D.N.Y. 1997).

249. Id. 
Throughout the relevant period, Metro-North had written nondiscrimination policies and formal procedures for promotion and discipline, including hearing and appeal rights for disciplinary sanctions. ${ }^{250}$ Plaintiffs conceded that these policies and procedures were nondiscriminatory and in fact well designed to guard against discrimination. ${ }^{251}$ Plaintiffs claimed, however, that Metro-North delegated responsibility to individual supervisors without adequate oversight and that this practice created a work environment that allowed for arbitrary and subjective decisionmaking and opened the door to employment outcomes biased against African Americans. ${ }^{252}$

The class that plaintiffs sought to represent included all AfricanAmerican employees in all thirty-seven departments and 220 job positions throughout the company. ${ }^{253}$ To satisfy the typicality and commonality requirements for certification of a company-wide class, ${ }^{254}$ plaintiffs had to show that Metro-North "discriminated against class members in some general fashion"; ${ }^{255}$ in other words, that the discriminatory practices reflected discrimination at the company level. ${ }^{256}$ Without such a showing, discrimination would be only a localized phenomenon confined to particular supervisors or departments and would have to be challenged on a more localized level, perhaps through individual suits or smaller class actions limited to specific departments.

To establish company-wide discrimination, plaintiffs relied on expert reports from a statistician and a sociologist, as well as anecdotal evidence. ${ }^{257}$ The sociological and anecdotal evidence played only a minor role; the District Court and Court of Appeals focused mainly on the statistical report, which they treated as the essential core of the certification analysis. ${ }^{258}$ The plaintiffs' statistical report used a regres-

\footnotetext{
250. Caridad v. Metro-North Commuter R.R., 191 F.3d 283, 286-87 (2d Cir. 1999) (citing the May 14, 1996 Report of Dr. Harriet Zellner).

251. Robinson, 175 F.R.D. at 49.

252. Id.

253. Id. at 47 .

254. FED. R. CIV. P. 23(a)(2), (3).

255. Robinson, 175 F.R.D. at 48.

256. Gen. Tel. Co. of the Southwest v. Falcon, 457 U.S. 147, 159 n.15 (1982). For a discussion of the Falcon case and its impact on class certification, see supra notes 57-62 and accompanying text.

257. Robinson, 175 F.R.D. at 48-49.

258. Id.; Caridad v. Metro-North Commuter R.R., 191 F.3d 283, 292 (2d Cir. 1999).
} 
sion model to isolate race-based effects. ${ }^{259}$ With respect to discipline, for example, plaintiffs' expert found that African Americans were disciplined three and one-half times more frequently than whites and that this difference was highly significant statistically. ${ }^{260}$ She estimated that a difference this large would occur by chance less than one time in ten thousand and concluded that the result supported plaintiffs' allegations. $^{261}$

Metro-North's expert objected that the regression model combined all the data for the various Metro-North departments, positions, locations, and jobs, and calculated a racial differential for the company as a whole. ${ }^{262}$ Combining disparate data in this way obscured localized distinctions and made it impossible to detect differences across departments, positions, locations, and other relevant factorseven if such differences were pervasive. ${ }^{263}$ In effect, the model averaged all the differences together to deliver a single "companywide" result and therefore could not indicate whether African Americans were being disciplined more than whites in one department, two locations, three job titles, or the entire company.

These expert positions remained essentially unchanged throughout the several rounds of affidavits, replies, and rebuttals. ${ }^{264}$ The plaintiffs' expert insisted that only a company-wide analysis using regression methods could determine if there was a racial difference at the company level, while the defendant's expert continued to object on the ground that the statistical model assumed rather than proved a single company-wide effect. ${ }^{265}$ The defendant's expert also presented

259. The model assumed that there was a single difference between white and AfricanAmerican discipline rates across the entire company. That difference could be positive, negative, or zero. See Caridad, 191 F.3d at 288 (citing the May 14, 1996 Report of Dr. Harriet Zellner).

260. Id. Although there were important differences between the promotional and disciplinary analyses, we only discuss the disciplinary analysis here as the issues cited by the courts were common to both.

261. Id.

262. Id.

263. Id.

264. Plaintiffs' expert responded to the criticism by filing an affidavit presenting the results of regression analyses run by department, thereby allowing for the possibility that racial differences in discipline rates could differ by department. Caridad, 191 F.3d at 289. But this analysis only controlled for departments and did not test the significance of other race-neutral factors such as job or location.

265. Id. at 288-89. 
his own analysis that showed substantial differences across various groupings within the proposed class. ${ }^{266}$

\section{B. District Court Decision}

The district judge denied certification. ${ }^{267} \mathrm{He}$ concluded that the plaintiffs' statistics were flawed because they combined data from across the company in a way that did not permit testing for localized effects:

[P]laintiffs' statistics, even taken most favorably to plaintiffs, cannot carry their burden here, because they fail to take account of the fact that different Metro-North positions have materially different individual rates of discipline and of promotion associated with them.... Unless these differences are taken into account, plaintiffs' global statistics are meaningless. ${ }^{268}$

The judge found that "when these differences are taken into account, no statistically significant racial disparities, either for discipline or promotion, can be established with respect to the great majority of the positions at Metro-North" and that "if there is any discrimination, it is localized to a few positions and individuals, insufficient to support a company-wide class." ${ }^{269}$

The district court's approach is similar to the one we recommend for our modest proposal. Before reaching his decision, the judge allowed the parties to take some discovery and gave them ample opportunity to dispute the expert evidence. He did not require that the plaintiffs actually prove company-wide discrimination, only that they provide statistical evidence to "meaningfully support" such an inference. ${ }^{270} \mathrm{We}$ recommend a different formulation of the threshold standard-"likelihood of success" rather than "meaningfully support"but in either case the trial judge must probe the evidence to determine whether the issues relevant to certification are sufficiently strong to pass the threshold. In this regard, the district judge did not assess the merits of the case as a whole. He instead focused on the expert reports and statistical evidence bearing on the merits only

\footnotetext{
266. See id. (finding little difference in promotion rates by race when excluding jobs for which the promotion rate was less than one percent).

267. Robinson v. Metro-North Commuter R.R. Co., 175 F.R.D. 46, 46 (S.D.N.Y. 1997).

268. Id. at 48 .

269. Id. at $48-49$.

270. Id. at 49 .
} 
insofar as it shed light on the certification issues, and in particular on the pivotal Rule 23 issue of company-wide discrimination.

\section{Court of Appeals Decision}

The plaintiffs appealed, and the Second Circuit Court of Appeals reversed. ${ }^{271}$ The ground for reversal had nothing to do with the substance of the district court's conclusion that the plaintiffs' statistical report was flawed. Indeed, the Court of Appeals itself expressed reservations about the plaintiffs' ability to prove company-wide discrimination, noting in particular that the plaintiffs' delegation theory is "likely to be extremely difficult" to prove and might well require more detailed statistical evidence. ${ }^{272}$ Instead, the Court, relying on Eisen, objected to the district judge reaching the merits at all: ${ }^{273}$

Though Metro-North's critique of the Class Plaintiffs' evidence may prove fatal at the merits stage, the Class Plaintiffs need not demonstrate at this stage that they will prevail on the merits. Accordingly, this sort of "statistical dueling" is not relevant to the certification determination.... We conclude that the Class Plaintiffs' statistical evidence supports a finding of commonality on the issue of discipline.... In addition, the statistical evidence supports a finding of commonality on the promotion claim.... Here, the District Court credited Metro-North's expert evidence over that of the Class Plaintiffs. Such a weighing of the evidence is not appropriate at this stage in the litigation. ${ }^{274}$

The district court and the appeals court took very different approaches to the certification question. The district court examined the plaintiffs' statistical evidence with some care and assessed its sufficiency in light of the standards for class certification. The appeals court, on the other hand, relied on Eisen to avoid this sort of examination. In the view of the appeals court, it was enough that plaintiffs had advanced statistical evidence that appeared on its face to support certification. That defendants disagreed with the sufficiency of the statistical proof did not mean certification should be denied; any dis-

\footnotetext{
271. Caridad v. Metro-North Commuter R.R., 191 F.3d 283, 283 (2d Cir. 1999).

272. Id. at 291.

273. Id. (citing Sirota v. Solitron Devices, Inc., 673 F.2d 566, 570-72 (2d Cir. 1982), which stated that "a motion for class certification is not an occasion for examination of the merits of the case").

274. Id. at 292-93.
} 
agreement between experts constituted "statistical dueling" that should be deferred until after certification.

\section{Aftermath}

Following the district court's initial denial of certification, several of the twenty-two named plaintiffs voluntarily dismissed a number of their claims, and Metro-North moved for summary judgment on most of the remaining claims. ${ }^{275}$ The trial judge granted summary judgment for all those claims that were time-barred or lacked sufficient evidence. ${ }^{276}$ After this, only seven of the original twenty-two plaintiffs and only a few of the original claims remained in the case. ${ }^{277}$

After remand from the Second Circuit, the plaintiffs renewed their motion to certify a class. The judge denied the motion once again, this time on the ground that the requirements of Rule 23(b) were not satisfied. ${ }^{278}$ The plaintiffs appealed that decision, and the Second Circuit again reversed, instructing the district judge to certify a class for at least part of the case. ${ }^{279}$ Finally, Metro-North settled all the cases that survived summary judgment, although with an option for the settling plaintiffs to rejoin the class should the district court's second denial be overturned on appeal (as in fact it was). ${ }^{280}$

\section{E. Conclusions and Lessons}

The Second Circuit's decision in Caridad reflects the unfortunate legacy of Eisen. The practical result is to insulate almost any expert's statistical evidence from challenge at the certification stage and virtu-

275. See Robinson v. Metro-North Commuter R.R. Co., No. 94 Civ. 7374, 1998 U.S. Dist. LEXIS 373, at *2 \& n.1 (S.D.N.Y. Jan. 15, 1998) (listing the claims that were voluntarily withdrawn and the claims targeted for summary judgment).

276. Id. at *3-*33. Significantly, plaintiffs again submitted the same statistical report and expert affidavits in support of their individual cases. However, the district judge rejected the evidence on the ground that generalized statistics could not be used to overcome summary judgment after the defendant made an individualized showing of nondiscriminatory reasons for an employment decision. Id. at $* 29-* 32$.

277. Id. at *3.

278. Robinson v. Metro-North Commuter R.R. Co., 197 F.R.D. 85, 86 (S.D.N.Y. 2000).

279. See Robinson v. Metro-North Commuter R.R. Co., 267 F.3d 147, 162, 172 (2d Cir. 2001) (holding that the compensatory damages requests do not necessarily preclude (b)(2) certification of the pattern-or-practice disparate treatment claim and that bifurcation does not necessarily violate the Seventh Amendment). The Second Circuit did not address the Eisen issue in this opinion, but it did cite Eisen to support the proposition that the appeal does not involve the merits of the case. $I d$. at 163 .

280. Robinson, 197 F.R.D. at 89-90. 
ally guarantee plaintiffs' success in establishing certification requirements when they depend on such evidence. In the context of employment discrimination class actions like Caridad, this means almost certain certification of a company-wide class even when the evidence for company-wide discrimination is seriously flawed. This is a prescription for high error risks and a strong inducement to frivolous class action suits.

Both the approach and the decision of the district court strike a much better balance in line with the error-cost analysis in Part III of this Article. First, the district judge minimized the likelihood of error by focusing the inquiry and giving the parties a chance to conduct discovery and dispute the plaintiffs' statistical report. Second, the balance of error costs favored the denial of certification on the evidence before the court. Any error in denying certification still would leave legitimate victims with ample alternatives to vindicate their claims. For example, class members could seek certification of smaller classes limited to more localized areas of discrimination, or pursue individual claims separately or together with others as co-parties.

On the other hand, a grant of certification was very likely to be erroneous. Plaintiffs had ample opportunity to cure the deficiencies in their statistical study and to obtain more compelling evidence of discrimination on the company level. Their inability or unwillingness to do so at least raises doubts about the existence of such a broad-based practice. So too, the fact that only some of the claims of only seven of the original twenty-two plaintiffs remained after summary judgment reinforces these doubts, and also raises questions about the viability of the individual claims. ${ }^{281}$ Indeed, this dismal summary judgment record, although not decisive on the point, at least suggests a strategy aimed at using class certification to leverage settlements for frivolous or weak cases.

As we have discussed, the mere certification of a class action makes settlement likely by shifting a tremendous amount of bargain-

281. A number of claims were dismissed because the plaintiffs did not present any specific evidence at all to counter the particularized nondiscriminatory reasons Metro-North offered for its employment actions. Robinson v. Metro-North Commuter R.R. Co., No. 94 Civ. 7374, 1998 U.S. Dist. LEXIS 373, at $* 2 \&$ n.1 (S.D.N.Y. Jan. 15, 1998). Moreover, for some of the other claims, the plaintiffs' evidence was blatantly inadequate. $I d$. at $* 31 \mathrm{n} .10$. In fact, the trial judge made a point of noting that "[ $\mathrm{t}] \mathrm{h}$ e analysis undertaken on this [summary judgment] motion has served ... to confirm the Court's view that the claims alleged in the instant Complaint are, for the most part, entirely discrete and unrelated to one another, and thereby singularly inappropriate to support a class action." Id. at *16 n.5. 
ing power to the plaintiffs. Caridad itself illustrates the stark difference for the exposure that defendants face when a case is certified and when it is not. With certification, Metro-North may face claims for many millions of dollars in compensatory and punitive damages plus attorneys' fees.

The Second Circuit's refusal to allow an inquiry into the merits can be explained only on the assumption that the court believed erroneous grants of certification were preferable to erroneous denials. This assumption, in turn, seems predicated on a belief that faulty statistics can be detected later in a case and probably also on a sense that assessing the validity of statistics is too difficult at the class certification stage. These considerations are seriously misguided. Faulty statistics never will be detected if the class action settles after certification-as most class actions do. Moreover, an examination of statistical evidence is often quite manageable at the certification stage, especially as the trial judge's task is limited to evaluating a threshold standard rather than rendering a final decision. Indeed, the trial judge in Caridad did not seem overly burdened by the task.

In sum, granting certification in Caridad created a substantial risk that frivolous claims would be rewarded, whereas denying certification was likely to save judicial resources in the long run and avoid socially undesirable settlement incentives without depriving legitimate victims of the opportunity to vindicate their claims. The result of the district court's certification denials in Caridad shows the benefits: Metro-North was able to test the merits of individual claims through summary judgment without risking enormous liability, and plaintiffs whose cases survived summary judgment were able to obtain reasonable settlements.

\section{The Ambitious Proposal: A Merits Review for All CASES}

The previous analysis clearly supports our modest proposal that judges be required to conduct a preliminary inquiry into the merits insofar as necessary to evaluate properly Rule 23's certification requirements. Rule 23 calls for a "rigorous analysis" of each certification requirement. ${ }^{282}$ Moreover, as we have seen, some of those requirements, such as commonality, typicality, predominance, and

282. See Gen. Tel. Co. of the Southwest v. Falcon, 457 U.S. 147, 161 (1982) (noting that a class action may be certified only "if the trial court is satisfied, after a rigorous analysis, that the prerequisites of Rule 23(a) have been satisfied"). 
superiority, call on the court to predict the likely litigation path of the lawsuit, and this kind of prediction often requires an evaluation of the strength of issues on the facts of the case. The Eisen rule, in effect, imposes an independent constraint on the scope of the certification inquiry in the name of avoiding prejudice, maintaining procedural purity, reducing errors, and conserving litigation resources. Such a constraint might be an acceptable gloss on Rule 23 if its purported benefits were clear and substantial enough. But they are not.

Our policy arguments also have broader implications. The errorand process-cost analysis supports our more ambitious proposal that judges conduct a merits review as part of every certification decision regardless of whether merits-related issues are directly relevant to a certification requirement. Limited precertification discovery would be allowed on all the salient issues in the case, and the trial judge would make and justify a determination whether class members' substantive claims have a significant likelihood of success. The merits inquiry need not be elaborate or extensive. The goal would be to avoid certifying class actions when the class claims are all substantively frivolous or extremely weak.

All the elements of the policy analysis developed in Part III apply with equal force to this broader proposal. A preliminary screening of the merits in all class actions will help deter frivolous suits by controlling abuse of the settlement leverage certification creates. Moreover, the various factors we discussed limit the error costs associated with false certification denials. Thus, our ambitious proposal is a considerable improvement over the current approach, which ignores the merits and invites frivolous and weak class action suits.

Whether the proposal is optimal is more difficult to determine. A merits screening generates costs, but the other principal approaches, such as strict pleading and penalties for frivolous filings, do so as well. For example, strict pleading, which requires class plaintiffs to plead claims in detail, creates error costs by making it harder for meritorious plaintiffs to file legitimate class action suits and also increases process costs by inviting more motions to dismiss. ${ }^{283}$ Moreover, because penalties must be set quite high to have a substantial impact on filing incentives, the use of a penalty approach can deter risk-averse plaintiffs from filing meritorious suits, and because hearings must precede the imposition of penalties, process costs can rise as well. ${ }^{284}$

283. See, e.g., Bone, supra note 149, at 587-89 (describing the costs of strict pleading).

284. See id. at 589-93 (evaluating the case for Rule 11 penalties). 
Although the paucity of empirical evidence makes it difficult to determine the precise combination of devices that strikes the best cost-benefit balance, preliminary merits screening is attractive enough and a substantial enough improvement over the status quo to warrant implementation, either on its own or in conjunction with other approaches. ${ }^{285}$ As courts gain experience with merits screening in practice, they will have a basis to make improvements that enhance the cost-benefit balance-by adjusting the scope of precertification discovery, altering the threshold level of likelihood of success, or tinkering with other features. Experience also can provide insight into the mix of different approaches best designed to deter frivolous class action suits.

\section{CONCLUSION}

Ever since the Supreme Court decided the Eisen case, the federal courts have struggled to make certification decisions without inquiring too deeply into the merits. The result, as we have seen, is a confused and misguided body of case law. When a judge wishes to avoid difficult evidentiary issues, to pressure a settlement, or to further his own policy views, he easily can ignore the merits and certify a class by relying on the Eisen rule. When a judge would rather examine the merits to screen out frivolous suits, he must confront the Eisen rule and somehow deal with its bar. The result is a practice of certification that generates high social costs over the long run, costs that are easily overlooked when deciding a particular case.

It is, therefore, time to abolish the Eisen rule. We have shown that the rule is not required by Rule 23 itself or justified by the Eisen Court's concern with the prejudicial effect of a preliminary merits review. Nor is the rule mandated by a proper understanding of the substance/procedure dichotomy or by basic principles fundamental to the framework established by the Federal Rules of Civil Procedure. Most disturbing of all, the Eisen rule provides fertile ground for frivolous suits and unjustified settlements that create substantial error costs.

285. Merits screening has the advantage of targeting frivolous suits directly rather than indirectly through incentive effects that can have a deleterious impact on meritorious suits. Moreover, the fact that screening happens before certification means that its effects are less likely to be blunted by settlement. Finally, error and process costs can be reduced by controlling the scope of precertification discovery and adjusting the threshold likelihood of success standard. Cf. id. at 593-96 (recommending judicial screening as a superior device to strict pleading, penalties, and fee-shifting for deterring frivolous suits outside the class action setting). 
As our discussion of the Caridad case demonstrates, there are substantial advantages to abandoning the Eisen rule and allowing a preliminary inquiry into the evidence and the merits. This is certainly true for our modest proposal, where merits-related issues are relevant to certification requirements. A party should be required to show a threshold likelihood of success before relying on an issue as part of the certification analysis. Moreover, trial judges should do whatever is necessary to evaluate each certification requirement rigorously. When this evaluation involves making a preliminary determination of the merits of claims or issues, the judge should make the necessary determinations explicitly and explain why, in light of the evidence, each certification requirement is or is not met. It might be tempting for the judge to skirt over technical and complex evidence or to certify when certification seems to be the only hope for plaintiffs with small claims, especially when settlement insulates a questionable decision from appellate review. But doing so is not only costly; it also is contrary to the intent and purpose of Rule 23.

In addition, we have demonstrated that the policy arguments favor our more ambitious reform. The error- and process-cost analysis supports a merits review as part of every certification decision whether or not merits-related issues are directly relevant to a specific certification requirement. Class certification should be granted only if the judge is persuaded, on a preliminary evidentiary review, that the individual suits comprising the class are not substantively frivolous or very weak on the merits.

The Advisory Committee on Civil Rules currently is considering revisions to Rule 23 and easily could include our proposals among its recommendations. The Committee has considered similar provisions in the past but never adopted them. ${ }^{286}$ Its refusal to act then was a mistake, and it now has an opportunity to correct the error.

Civil litigation is a complex strategic environment that challenges our powers of prediction and analysis. Because of this, we must be especially careful to evaluate costs as well as benefits and adjust our procedural rules in light of changing conditions and practical experience. The Eisen rule was adopted without serious attention to its

286. See, e.g., HENSLER ET AL., supra note 34, at 28-30 (discussing a proposed Rule 23 revision considered by the Committee in 1995 and 1996 that would have required trial judges to consider the likely success of the class action before certification); see also Berry, supra note 4, at 323, 334-37 (describing a bill, developed with the help of the Justice Department and introduced before Congress in 1978, that would have revised class action practice to include, among other things, a preliminary assessment of the merits). 
costs, and it no longer serves a class action world dominated by settlement. Overturning Eisen will not cure all class action problems, but it will make the class action a more effective tool for achieving efficiency and enforcing substantive rights. That would be an important step forward. 